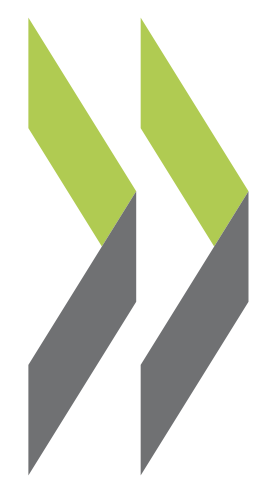

OECD Economics Department Working Papers No. 451

\title{
Product Market Competition and Economic Performance in Australia
}

Helmut Ziegelschmidt,

Vassiliki

Koutsogeorgopoulou,

Simen Bjornerud,

Michael Wise 
Organisation de Coopération et de Développement Economiques

Organisation for Economic Co-operation and Development

13-Oct-2005

ECONOMICS DEPARTMENT

English - Or. English

PRODUCT MARKET COMPETITION AND ECONOMIC PERFORMANCE IN AUSTRALIA

ECONOMICS DEPARTMENT WORKING PAPER No. 451

by Helmut Ziegelschmidt, Vassiliki Koutsogeorgopoulou, Simen Bjornerud and Michael Wise

All Economics Department Working Papers are now available through OECD's internet web site at http://www.oecd.org/eco. 


\section{ABSTRACT/RÉSUMÉ}

\section{Product market competition and economic performance in Australia}

The OECD Growth Study and other empirical work have shown that the strength of competition in product markets plays an important role in the economic growth process as well as contributing to a more efficient allocation of resources in a static sense. More intense competition is likely to encourage stronger efforts of managers to improve efficiency and induce higher innovative activity, leading to higher multi-factor productivity. This paper begins with a short review of Australia's growth performance since the early 1990s and its possible link to strengthened competitive pressures and their interaction with other economic reforms. Attention is then turned to indicators of product market competition to gauge the strength of competitive pressures. This is followed by an assessment of the general competition policy framework and its role in promoting competition. The next section presents the framework of the National Competition Policy and reviews the completeness of the reform programme and the areas requiring further action. The paper then examines a number of sectors where regulatory policies can be expected to have particularly large impacts. The implications of trade liberalisation on Australia's economic performance and the scope for further improvements are also discussed in some detail. The paper concludes with a set of policy recommendations.

JEL classification: K20, K21, H4, L50, L9, L94, L96, Q1, Q4

Keywords: National Competition Policy, NCP, Trade Practices Act, ACCC, Dawson Review, Legislation Review, multifactor productivity, access regime, electricity, gas, water, rail, road, air transport, telecommunications, television broadcasting, retail distribution, health, legal services, trade policy.

This Working Paper relates to the 2005 OECD Economic Survey of Australia (www.oecd.org/eco/surveys/australia).

\section{Résumé}

\section{Concurrence sur les marchés de produits et performance économique en Australie}

L'Étude sur la croissance de l'OCDE et d'autres travaux empiriques ont montré que la vigueur de la concurrence sur les marchés des produits joue un rôle important dans le processus de croissance économique et contribue aussi à une allocation plus efficiente des ressources du point de vue statique. Un renforcement de la concurrence encouragera vraisemblablement les gestionnaires à faire des efforts plus soutenus pour améliorer l'efficience et induire une activité plus novatrice, conduisant à une augmentation de la productivité multifactorielle. Ce document de travail commence avec un bref examen de la performance de l'Australie sur le plan de la croissance depuis le début des années 90 et de ses liens éventuels avec le renforcement des pressions concurrentielles et leur interaction avec d'autres réformes économiques. On s'intéressera aussi aux indicateurs de la concurrence sur les marchés des produits de façon à évaluer la vigueur des pressions concurrentielles. Cet examen est suivi d'une évaluation du cadre général de la politique de la concurrence et de son rôle dans la promotion de la concurrence. La section suivante expose le cadre de la politique nationale de la concurrence et analyse l'exhaustivité du programme de réformes et les domaines exigeant une action plus approfondie. Plusieurs secteurs où les politiques réglementaires devraient avoir une incidence particulièrement importante sont ensuite passés en revue. Les conséquences de la libéralisation commerciale sur la performance économique de l'Australie et les possibilités d'autres améliorations sont aussi examinées en détail. Le document se conclut par un ensemble de recommandations d'action.

Classification JEL: K20, K21, H4, L50, L9, L94, L96, Q1, Q4

Mots clés : Politique de la concurrence, NCP, Trade Practices Act, ACCC, Commission Dawson, révision de la législation, productivité multifactorielle, régime d'accès, électricité, gaz, eau, transport feroviaire, transport routier, transport aérien, télécommunications, télédiffusion, distribution de détail, professions de santé, professions juridiques, politiques commerciale.

Ce Document de travail se rapporte à l'Étude économique de l'OCDE de l'Australie, 2005 (www.oecd.org/eco/etudes/australie).

"Copyright OECD, 2005

Application for permission to reproduce or translate all, or part of, this material should be made to: Head of Publications Service, OECD, 2 rue André Pascal, 75775 Paris Cedex 16, France." 


\section{TABLE OF CONTENTS}

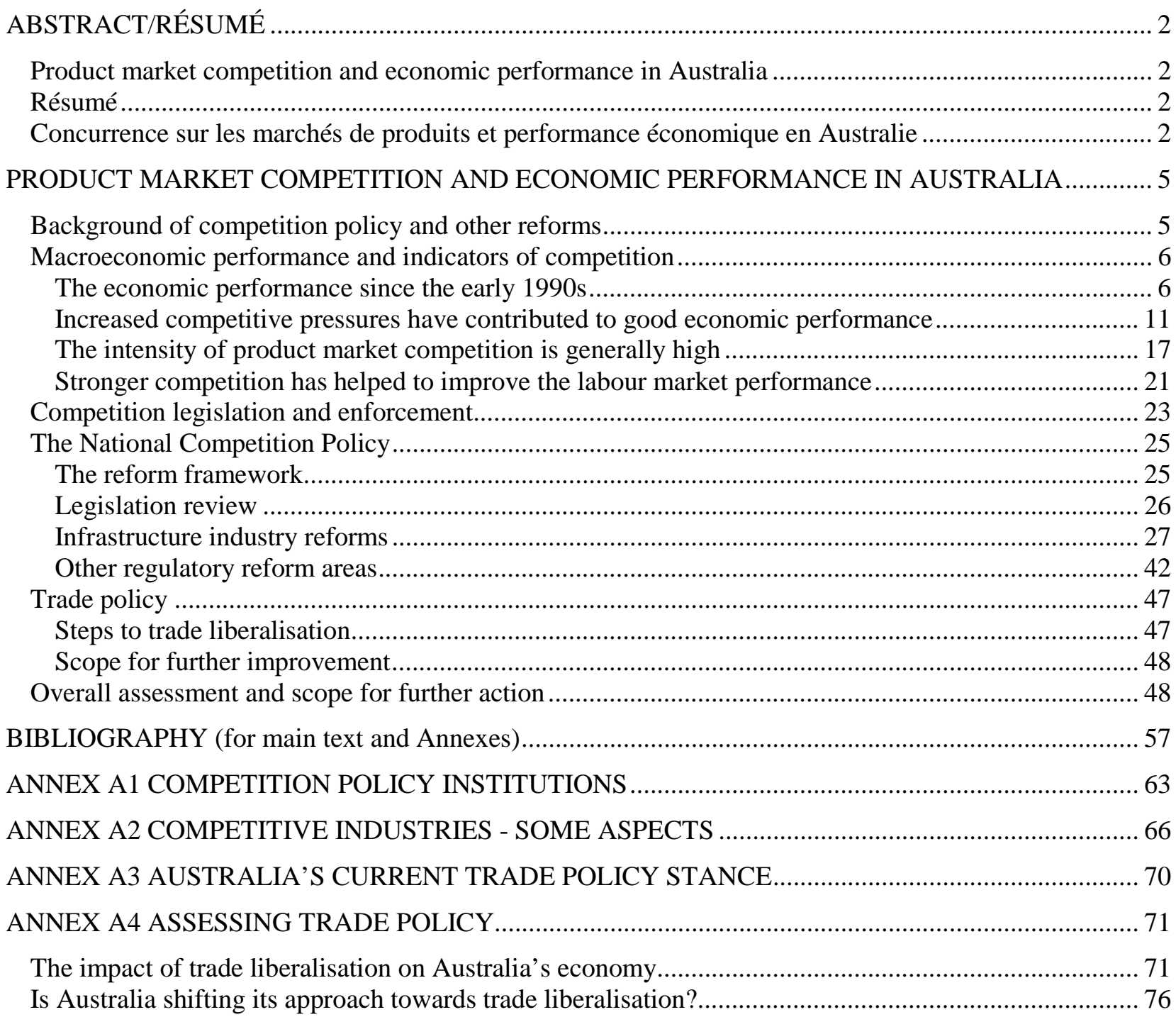

\section{Tables}

Table 1. Output, employment and productivity

Table 2. Growth in multifactor productivity by industry over aggregate productivity cycles ................. 13

Table 3. Ratio of the domestic to world price, 1991-1993 ................................................................. 19

Table 4. Status of jurisdictions' progress in implementing water reform components, as at May ........... 32

Table A 4.1. Exposure to international trade competition in selected OECD countries .......................... 73 


\section{Figures}

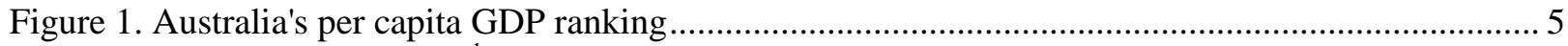

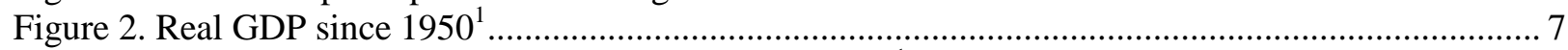

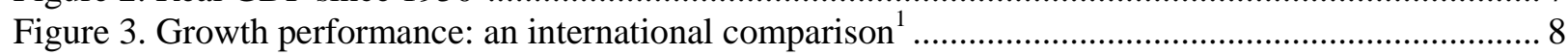

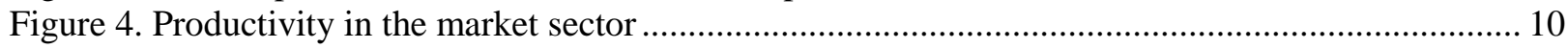

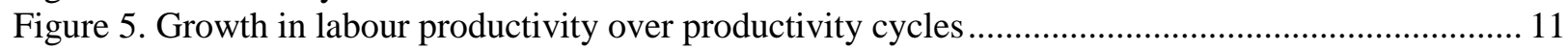

Figure 6. Progress in liberalisation of service sectors in OECD countries ............................................. 14

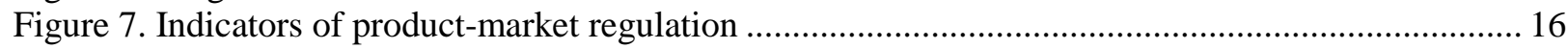

Figure 8. Effect of deregulation on the multifactor productivity gap relative to best practice................. 17

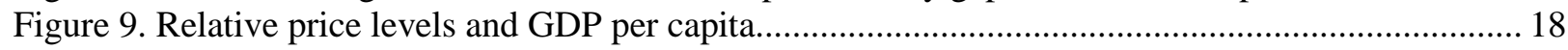

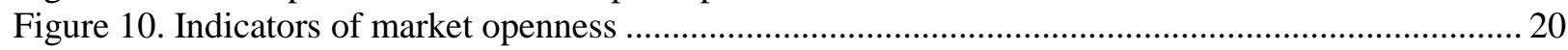

Figure 11. An international comparison of agricultural support ........................................................... 21

Figure 12. Product market liberalisation and labour market performance ............................................... 22

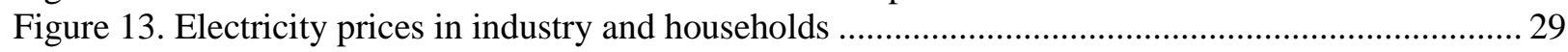

Figure 14. Real domestic air fares excluding taxes and charges, monthly index................................... 36

Figure 15. Real international charges for a B747-400 landing and takeoff by airport............................. 37

Figure 16. Real domestic charges for a B737-800 landing and takeoff by airport.................................. 37

Figure 17. Estimates of market shares of new entrants ........................................................................ 39

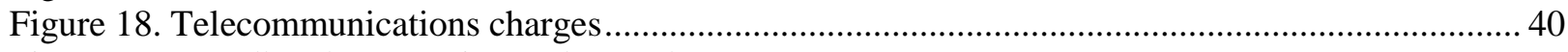

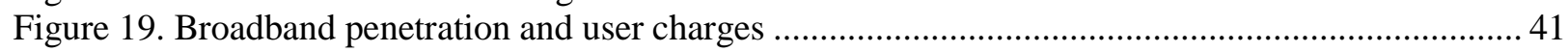

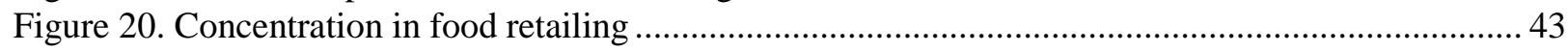

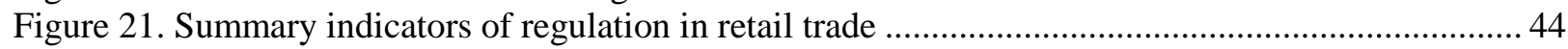

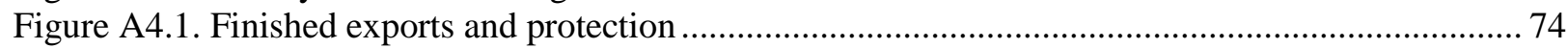

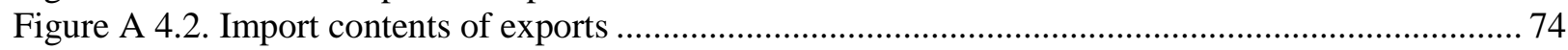

Figure A 4.3. Outward foreign direct investments ............................................................................ 75

Figure A 4.4. Average annual change in Australia's service trade ....................................................... 76

Figure A4.5. The evolution of Regional Trade Agreements in the world............................................. 77

\section{Boxes}

Box 1. Factors apparently not contributing to the 1990's multifactor productivity surge ...................... 12

Box 2. The effects of product market reforms on employment and unemployment ................................. 23

Box 3. Recommendations regarding product market competition.................................................... 51

Box A2.1. The Australian Government health legislation and its impact on competition ${ }^{1} \ldots \ldots \ldots \ldots \ldots \ldots \ldots . . . . . . . .67$

Box A4.1. A brief on Australia's trade policy evolution ........................................................................ 71 


\title{
PRODUCT MARKET COMPETITION AND ECONOMIC PERFORMANCE IN AUSTRALIA
}

\author{
By
}

\section{Helmut Ziegelschmidt, Vassiliki Koutsogeorgopoulou, Simen Bjornerud and Michael Wise ${ }^{1}$}

\section{Background of competition policy and other reforms}

1. The OECD Growth Study ${ }^{2}$ and other empirical work have shown that the strength of competition in product markets plays an important role in the economic growth process as well as contributing to a more efficient allocation of resources in a static sense. More intense competition is likely to encourage stronger efforts of managers to improve efficiency and induce higher innovative activity, leading to higher multi-factor productivity (MFP). Insufficient competition in the domestic economy is held to have accounted for much of the slippage in the growth in Australia's productivity and living standards in the 1970s and the first half of the 1980s, following the "Golden Age" of rapid economic growth after World War II. ${ }^{3}$ A large part of the economic slowing was attributable to the poor productivity record in infrastructure industries: for example, in 1990, productivity levels were less than one-half of those of Australia's trading partners in ports, railroads and electricity generation, and productivity in Australia's telecommunications industry was the lowest in nine countries examined by the OECD. ${ }^{4}$ Hence, Australia, which was near the top of 22 selected OECD countries in terms of per capita GDP in the 1950s, had fallen into the bottom third by $1990^{5}$ (Figure 1).

Figure 1. Australia's per capita GDP ranking

Selected OECD countries, purchasing power parity 1999 US\$

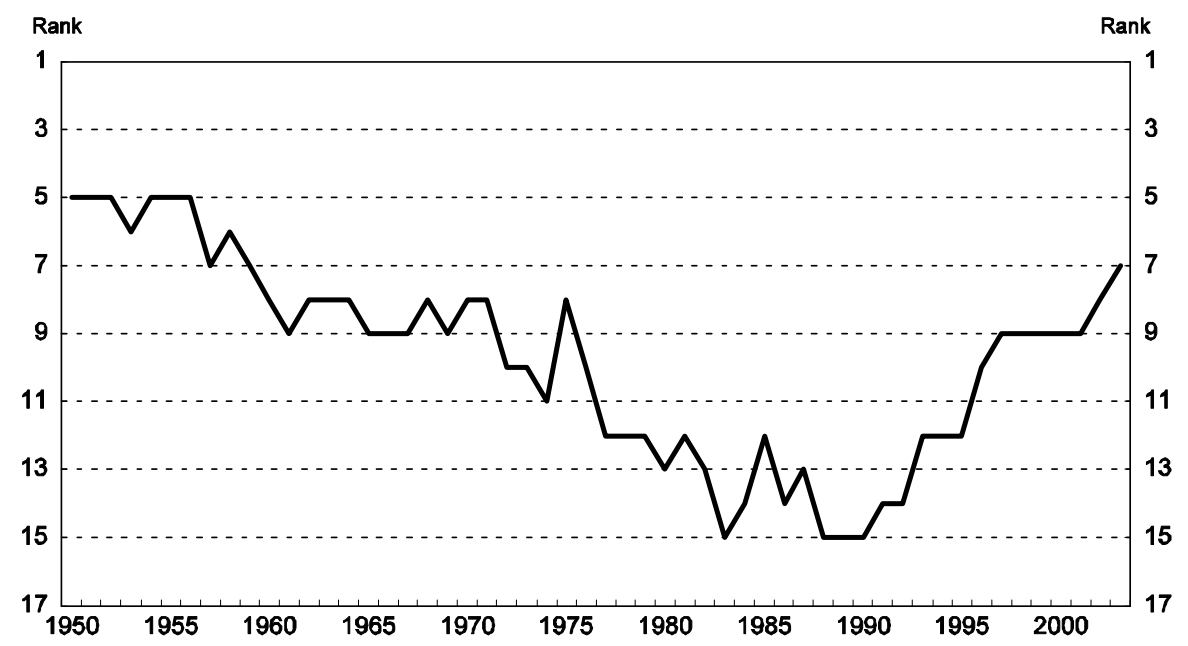

Source: University of Groningen, GGDC Total Economy Database, http://www.eco.rug.nl. 
2. Australia's falling behind other economies led to a wide-ranging series of reviews of existing policy strategies. ${ }^{6}$ A recurring theme in many such reviews was that prices frequently did not reflect the cost of supply, and that excessive government intervention was a factor underlying poor performance. As a result of these analyses, economic reforms were introduced progressively, which dominated Australia's political life through the 1980s and 1990s. These reforms included further marked reductions in barriers to trade $^{7}$ and foreign direct investment; floating of the currency; deregulation of access to finance; commercialisation and privatisation of government business enterprises; changing institutional arrangements to allow greater labour market flexibility; promotion of education, training and innovation; and a general strengthening of competition. To achieve the latter, the National Competition Policy (NCP) was established as a centrepiece of structural reforms in 1995; it is discussed below. Microeconomic reforms were complemented in the 1990s with stability-oriented fiscal and monetary policies which are set in a medium-term framework. ${ }^{8}$ Collectively, these reforms aimed at improving the allocation of resources and raising overall productivity by encouraging flexibility, technical efficiency and innovation in the economy on a broad basis, and fostering a more outward-oriented business culture.

3. The Working Paper continues with a short review of Australia's growth performance since the early 1990s and its possible link to strengthened competitive pressures and their interaction with other economic reforms. Attention is then turned to indicators of product market competition to gauge the strength of competitive pressures. This is followed by an assessment of the general competition policy framework and its role in promoting competition. The next section presents the framework of the National Competition Policy and reviews the completeness of the reform programme and the areas requiring further action. The paper then examines a number of sectors where regulatory policies can be expected to have particularly large impacts. The implications of trade liberalisation on Australia's economic performance and the scope for further improvements are also discussed in some detail. The Working Paper concludes with a set of policy recommendations.

\section{Macroeconomic performance and indicators of competition}

\section{The economic performance since the early $1990 \mathrm{~s}$}

4. The economic reforms launched since the mid-1980s were followed by an economic recovery which began in 1992 and which turned out to be the longest economic expansion since the 1960s. During this long upswing, Australia's real GDP per capita increased faster than in the preceding two decades (Figure 2). Moreover, Australia's growth performance between 1990 and 2003 was substantially above 
ECO/WKP(2005)38

Figure 2. Real GDP since $1950^{1}$

$1950=100, \log$ scale

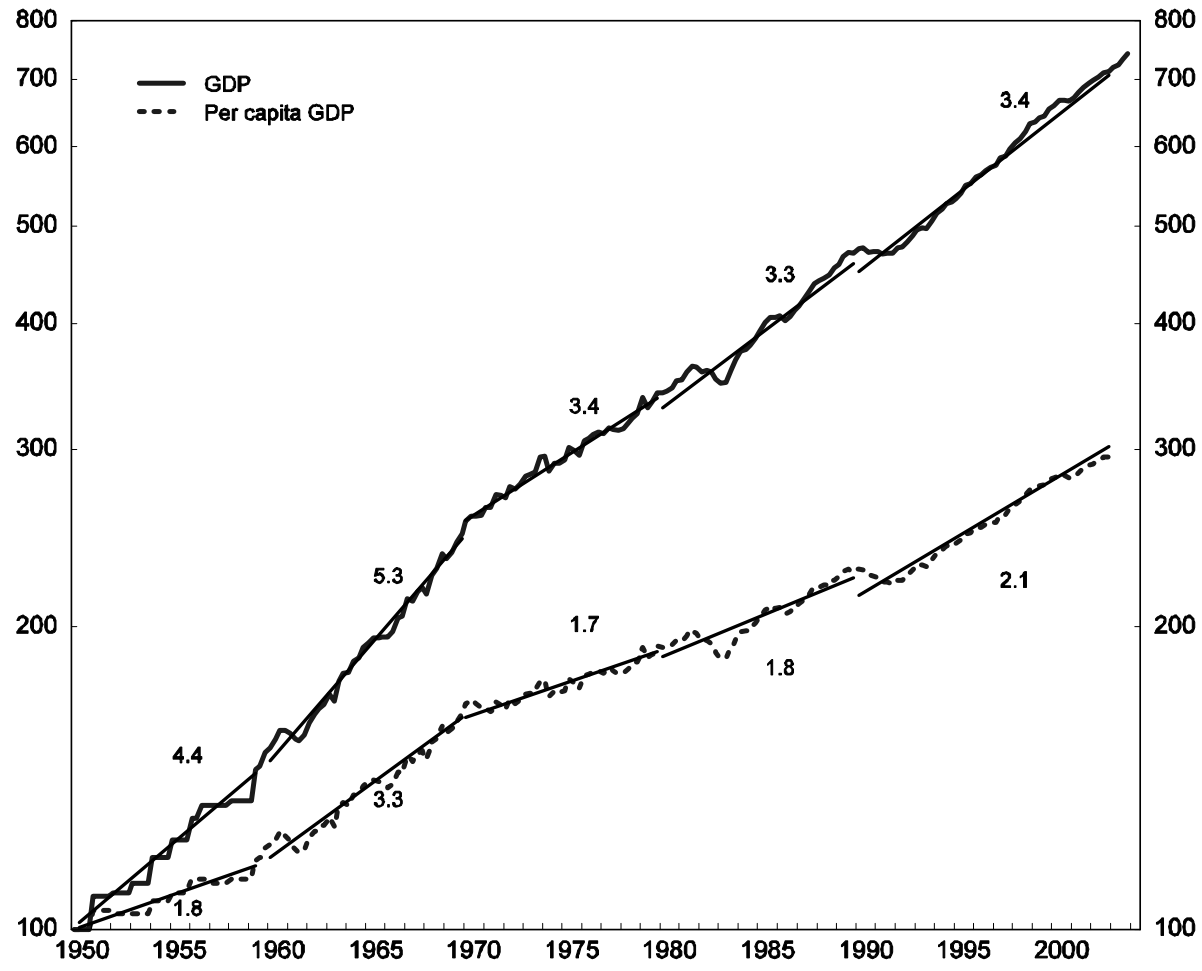

1. The figures in the diagram are the average growth rates during the periods defined by the straight lines.

Source: Australian Bureau of Statistics. 
Figure 3. Growth performance: an international comparison ${ }^{1}$

Annual average percentage changes over 1990 - 2003

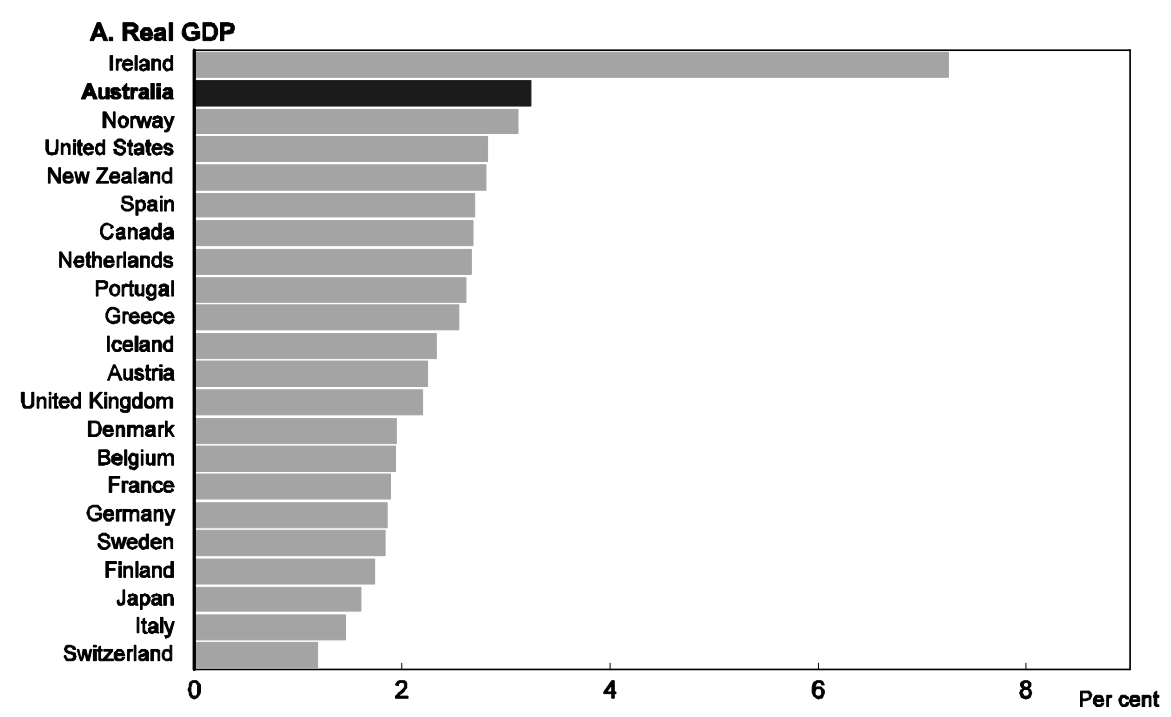

B. Real GDP per capita at constant PPPs

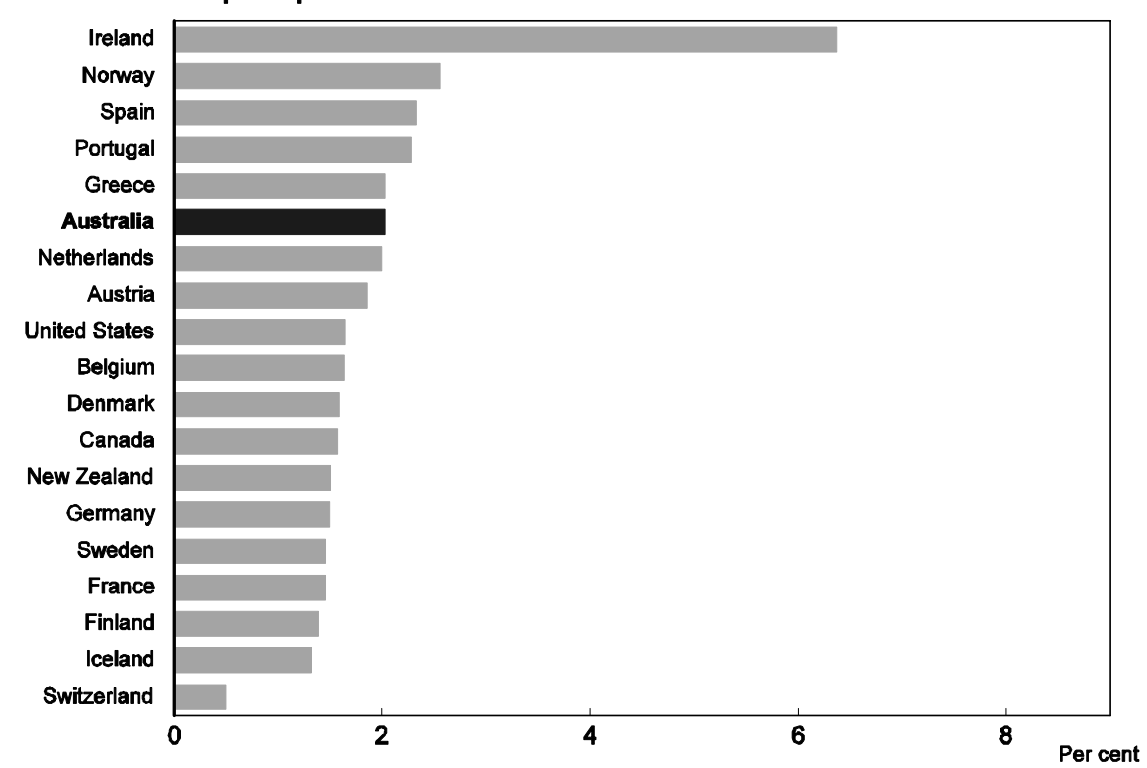

1. Or latest year available.

Source: OECD, Annual National Accounts Database.

the OECD and European Union averages, and is still on a rising trend (Figure 3). Growth of GDP per capita has also exceeded that of most individual OECD countries. ${ }^{9}$ As a result, Australia's international ranking in per capita GDP - at purchasing power parity ${ }^{10}$ (PPP) exchange rates - has rebounded from its low point of $15^{\text {th }}$ in 1990 to $7^{\text {th }}$ in 2003. Nevertheless, Australia's per capita income was between 75 and 80 per cent of the US level in 2003, around the level achieved already in 1950. 


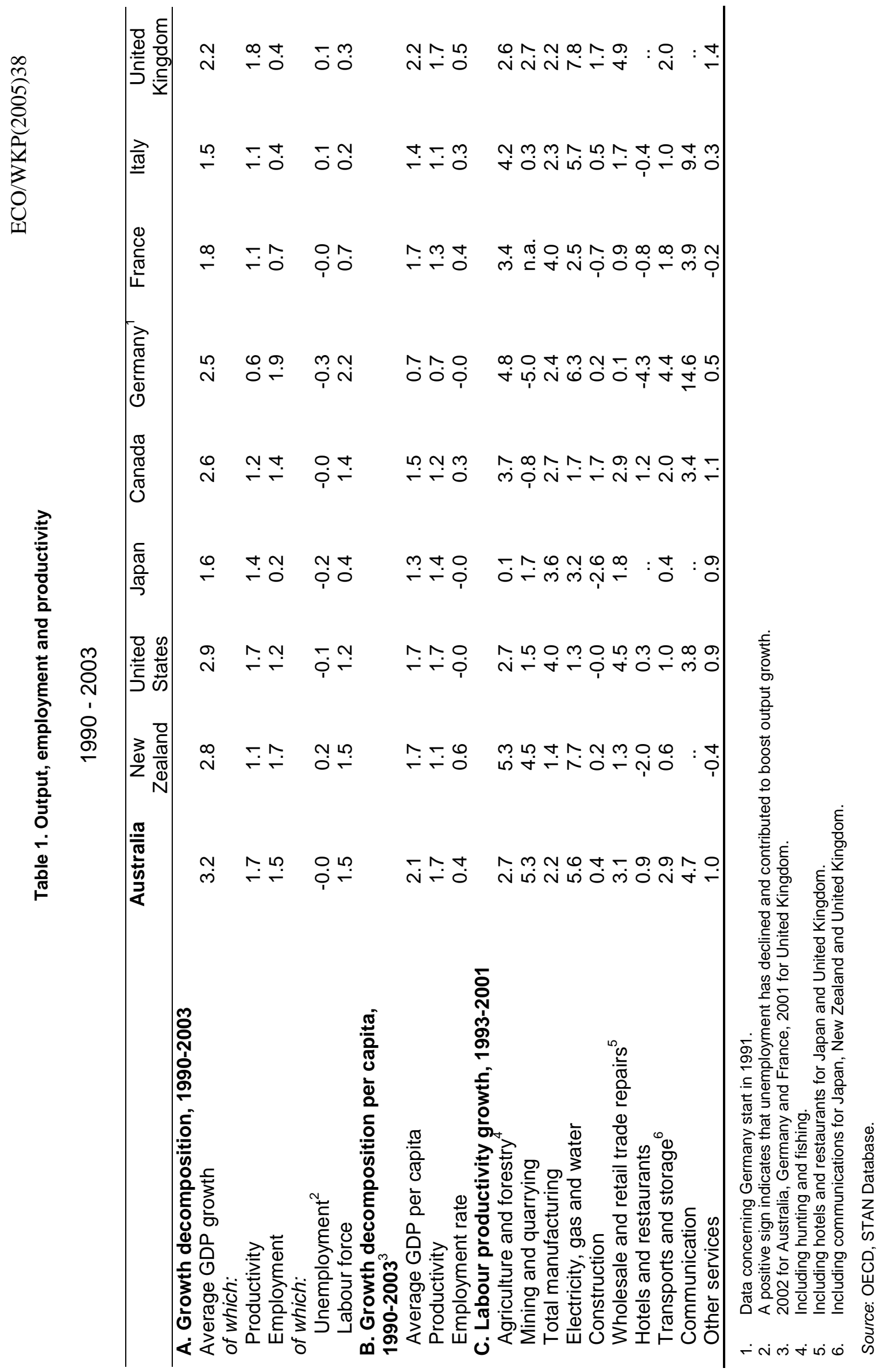


5. Economic growth in the 1990s owes more to gains in labour productivity than to higher employment rates (Table 1). Indeed, higher labour productivity growth accounts for more than 90 per cent in the acceleration in per capita income in the 1990s. Although productivity can be boosted by an increased use of capital equipment per unit of labour ("capital deepening"), the growth decomposition shown in Figure 4 reveals that there was no acceleration in capital deepening from the 1988-89 to 1993-94 productivity cycle to the 1993-94 to 1998-99 period. Accordingly, the additional labour productivity growth of more than one percentage point between the two latest productivity cycles was entirely driven by higher growth of multi-factor productivity ${ }^{11}$ (MFP) in the market sector, ${ }^{12}$ hence by the more efficient use of resource inputs (Figure 5). But with real GDP per hour worked at between 75 and $85 \%$ of the hourly productivity in the United States, there is still considerable scope for catching up.

Figure 4. Productivity in the market sector ${ }^{1}$

$2002 / 2003=100, \log$ scale

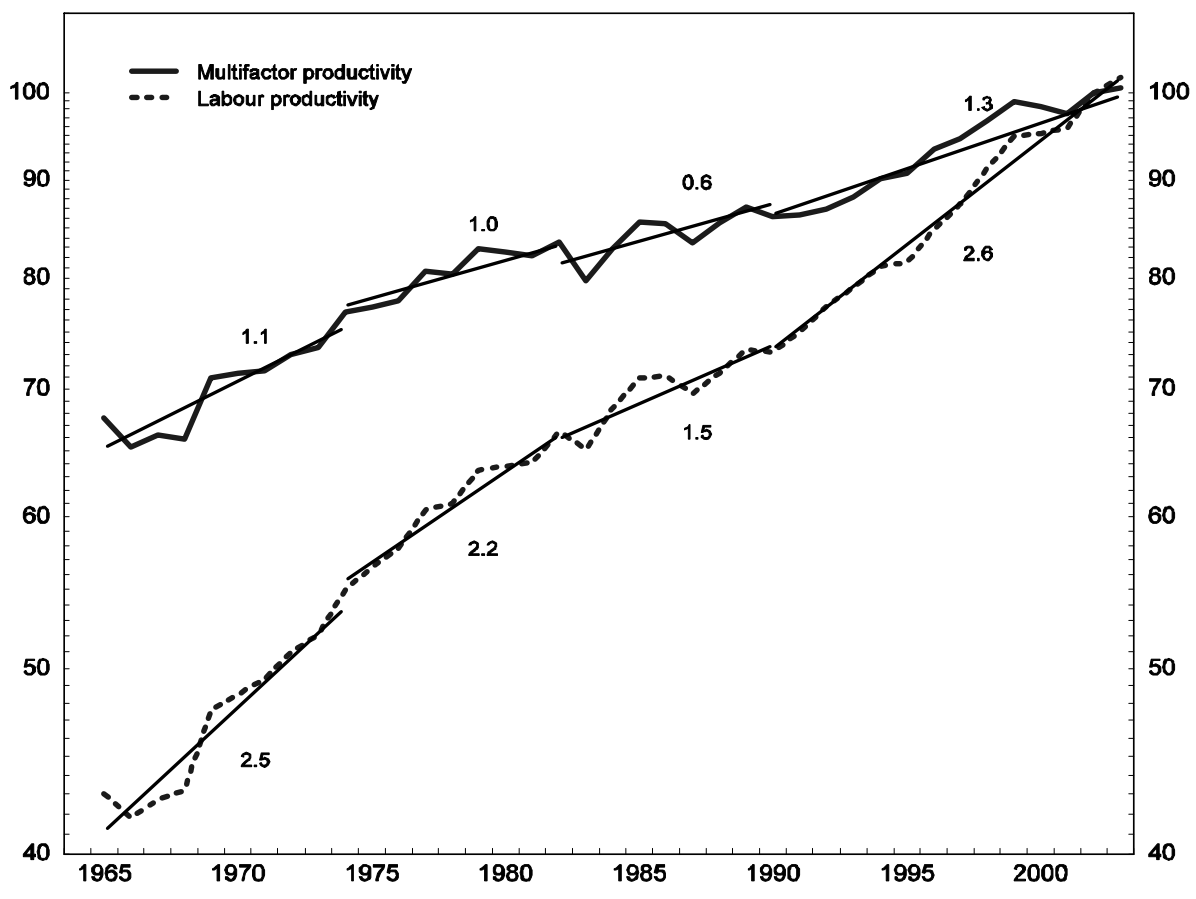

1. The figures in the diagram are the average growth rates during the periods defined by the straight lines.

Source: Australian Bureau of Statistics. 
Figure 5. Growth in labour productivity over productivity cycles, 1964-65 to 2002-03 ${ }^{1}$

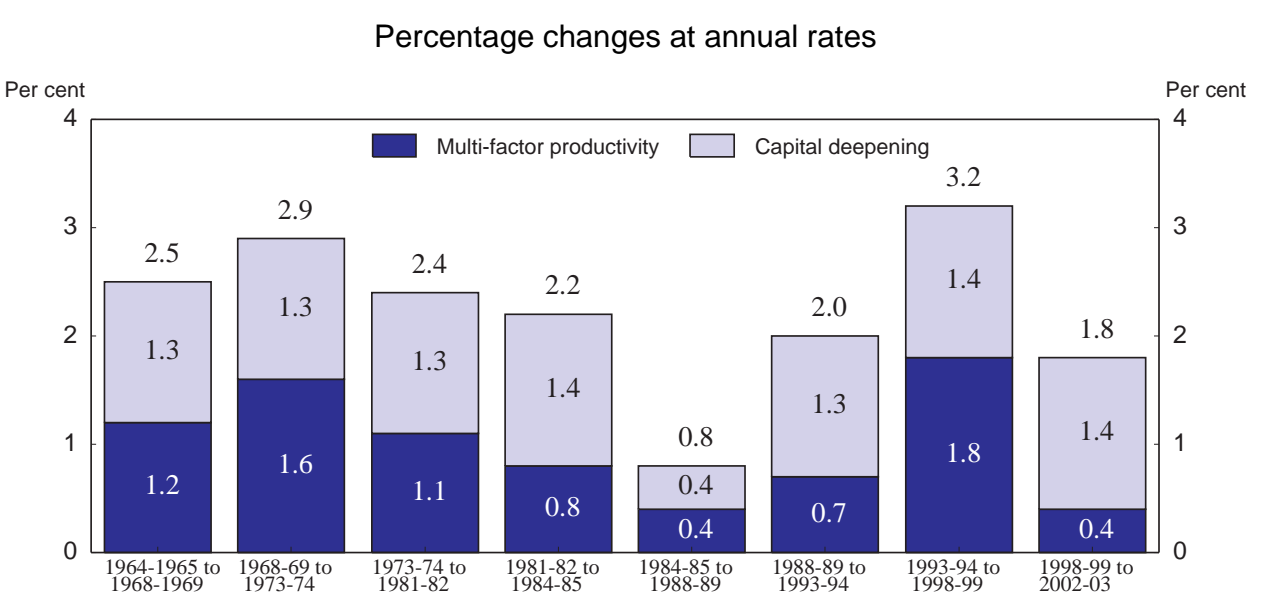

1. Productivity cycles are the intervals between productivity peaks, as identified by the Australian Bureau of Statistics. $1998-99$ to $2002-03$ is an incomplete productivity cycle.

Source: Productivity Commission and Australian Bureau of Statistics.

6. During the four years ending in the financial year 2002-03, capital deepening maintained its trend, but market sector MFP growth slowed down to an average rate of $0.5 \%$. This could indicate the end of its strong trend increase in the 1990s. However, productivity outcomes over recent years have been influenced by a series of major shocks. These were: the introduction of the goods and services tax (GST), which induced a pre-GST-implementation housing boom, followed by slump; the global economic weakness in 2001-02; and the drought in 2002-03. These shocks appear to have caused strong fluctuations in MFP growth estimates. The estimated decline in MFP in agriculture by about 20\% in 2002-03 alone accounts for a decline in total market sector MFP by a full percentage point. Conversely, the current recovery in the farm sector is set to boost its MFP in the near future. Finally, it is important to note that the latest productivity growth cycle is incomplete and comparisons with earlier complete cycles may be misleading.

\section{Increased competitive pressures have contributed to good economic performance}

7. Although the causal connections between structural reforms and economic performance are difficult to establish beyond doubt, there is broad agreement among researchers that competition policy and other microeconomic reforms have played a central role in Australia's productivity surge. ${ }^{13}$ They conclude that the reforms, with their focus on openness to foreign trade and investment and enhanced domestic competition, have been drivers and enablers of Australia's recent productivity growth (Productivity Commission, 2002a). The improved economic performance is also in broad accordance with ex ante estimates of the gains from microeconomic reform such as those of Filmer and Dao (1994) who predicted an acceleration of GDP growth by 1 percentage point in the first half of the 1990s and by $1 \frac{1}{2}$ percentage points in the second half, leading to a decline in the unemployment rate to a little above 5 per cent by 2001 . Previous model-based projects by the Industry Commission (1995) suggested that the major elements of the National Competition Policy could potentially generate a net benefit equivalent to $5 \frac{1}{2} 2$ per cent of GDP. More selective analysis, undertaken for the current Productivity Commission inquiry into the future of NCP, indicates that the observed productivity and price changes in key infrastructure sectors in the 1990s to which NCP and related reforms have directly contributed - have served to increase Australia's GDP by 2.5 per cent or $\$ 20$ billion (Productivity Commission 2004c). Although alternative explanations have been proposed for the acceleration in productivity growth during the 1990s, these have either been dismissed, or 
when credible, could only account for a comparatively small quantitative contribution to the productivity advance (Box 1).

\section{Box 1. Factors apparently not contributing to the 1990's multifactor productivity surge}

External factors: Unlike the 1960s and 1970s, there was no worldwide productivity boom which could have stimulated Australia's performance in the 1990s.

Cyclical forces: The 1990s productivity acceleration was too protracted to be explained as a purely cyclical phenomenon. Moreover, the ABS' measures of peak-to-peak productivity cycles adjust for much of the cyclical influences on trend productivity estimates.

Higher unmeasured labour inputs: Although there was a trend to longer working hours in Australia over the past two decades, this is already adjusted for in the ABS main labour productivity measure (output per hours worked). There is no evidence of any increase in unrecorded hours worked. Claims that industrial relations reforms have eroded working time standards (Quiggin 2000, 2001) were examined by Wooden (2003) and could not be confirmed. However, more effective use of labour during working hours is a genuine source of productivity gains.

Higher $\boldsymbol{R} \& \boldsymbol{D}$ spending: Although since the mid-1980s total R\&D expenditure has increased from 1.12 to 1.53 per cent of GDP, and business R\&D from 0.53 to 1.11 per cent of business value added, these indicators remain below the OECD average and are unlikely to have induced any significant technological leap forward in the 1990s.

Higher infrastructure spending: Australian public investment has been declining rather than increasing since the mid-1980s.

Effect of skills: Higher skill levels could have pushed up productivity levels but the accumulation of skills seems to have decelerated between the 1980s and 1990s (Parham, 2004). A small contribution from skills to MFP growth about 0.2 percentage point - from the mid-1980s to the late 1990s was reported by Barnes and Kennard (2002).

ICT effects: Rapid advances in the production of information and communication technology (ICT) are no credible explanation either because of the smallness of the sector in Australia (see the 2001 OECD Economic Survey of Australia). However, various studies (e.g. Bean 2000, Parham et al. 2001, Gretton et al. 2003) identified a productivity-enhancing effect from the increased use of ICT. Of the annual 1.1 percentage point acceleration in MFP growth that occurred in the 1990s - around 0.2 percentage points were attributed to the use of ICT between the 1990s growth cycles. This estimate is not uncontroversial, being based on growth accounting methods and an equilibrium assumption which may understate dynamic impacts. It also assumes that the timing of the acceleration has been correctly identified. It is not surprising then that a comparatively large part of the productivity acceleration remains unexplained. While the exact effect of ICT may be higher, it is certainly true that ICT investment alone is not sufficient for faster growth - other OECD countries also had this strong investment in ICT, but did not experience an acceleration in productivity growth. This suggests that other factors were important in this increase in the rate of growth. It also leaves open the question why Australia moved from a technological laggard in the 1970s and 1980s to a frontrunner in the 1990s, if it were not increased competitive pressures.

8. A look at sectoral multifactor productivity estimates may offer additional insight into the link between competition policy reforms and productivity performance (Table 2). The estimates show, for example, that the electricity, gas and water sector, which was previously dominated by uncompetitive public sector monopolies, substantially stepped up its multifactor productivity growth from the mid-1970s to the late 1990s, with the acceleration coinciding with the growing exposure of these industries to competitive pressures (Figure 6). The resulting productivity gains in infrastructure service industries have led to substantial cuts in infrastructure prices such as electricity, gas, water, sewage, urban transport, ports, railways and telecommunications (Productivity Commission 2002a). For example, during the 1990s, electricity prices for businesses fell between 30 and $60 \%$ in real terms; port authority charges fell in real terms by between 50 and $60 \%$ in Sydney and Melbourne; coal rail freight rates in the Hunter Valley fell by $60 \%$ in real terms; and the real price of telecommunication services fell by more than $20 \%{ }^{14}$ It also seems that these price reductions were not at the expense of service quality and that their magnitude was broadly similar in city and country areas. The Productivity Commission (2004c) notes that structural reforms are 
likely to have been the principal contributors to the improvements in productivity growth for the five year period to 1998-99 which provided the equivalent of an additional A \$7 000 to the 'average' household. It also estimated that if Australia could increase its productivity further, to levels equivalent to the United States, Australian household income would rise by some A $\$ 22000$ per year.

Table 2. Growth in multifactor productivity by industry over aggregate productivity cycles

Per cent, per year

\begin{tabular}{|c|c|c|c|c|c|c|}
\hline Industry & $\begin{array}{c}1974-1975^{1} \\
\text { to } \\
1981-1982\end{array}$ & $\begin{array}{c}\text { 1981-1982 } \\
\text { to } \\
\text { 1984-1985 }\end{array}$ & $\begin{array}{c}\text { 1984-1985 } \\
\text { to } \\
1988-1989\end{array}$ & $\begin{array}{c}1988-1989 \\
\text { to } \\
1993-1994\end{array}$ & $\begin{array}{c}\text { 1993-1994 } \\
\text { to } \\
1998-1999\end{array}$ & $\begin{array}{c}\text { 1998-1999 } \\
\text { to } \\
2002-2003\end{array}$ \\
\hline Agriculture & 2.7 & 3.0 & -1.6 & 4.2 & 4.2 & -2.1 \\
\hline Mining & -3.8 & 5.7 & 2.4 & 2.3 & 0.1 & 0.6 \\
\hline Manufacturing & 2.3 & 2.0 & 1.5 & 2.0 & 0.5 & 1.2 \\
\hline Electricity, gas and water & 2.2 & 1.2 & 5.1 & 4.0 & 1.8 & -2.0 \\
\hline Construction & 2.7 & -0.7 & -0.3 & -0.5 & 2.2 & 1.3 \\
\hline Wholesale trade & 0.5 & -2.5 & 1.8 & -2.2 & 5.8 & 1.9 \\
\hline Retail trade & 0.9 & 2.6 & -2.6 & 0.7 & 1.4 & 0.5 \\
\hline \multicolumn{7}{|l|}{ Accommodation, cafés } \\
\hline and restaurants & -0.5 & -2.9 & -1.4 & -1.9 & 0.8 & 0.1 \\
\hline Transport and storage & 3.4 & 1.9 & 1.4 & 1.3 & 2.3 & 3.4 \\
\hline Communication services & 6.1 & 3.2 & 3.6 & 6.1 & 5.1 & -1.0. \\
\hline Finance and insurance & -2.9 & -1.2 & 1.5 & 0.0 & 1.6 & -0.8 \\
\hline \multicolumn{7}{|l|}{ Cultural and recreational } \\
\hline services & -0.5 & -1.8 & -4.6 & -2.4 & -4.0 & -2.7 \\
\hline Total market sector & 1.1 & 0.8 & 0.4 & 0.7 & 1.8 & 0.4 \\
\hline
\end{tabular}

1. Because of lack of industry data for $1973-74$, the 1970 cycle in this table begins in 1974-75.

Source: Productivity Commission and ABS. 
Figure 6. Progress in liberalisation of service sectors in OECD countries ${ }^{1}$
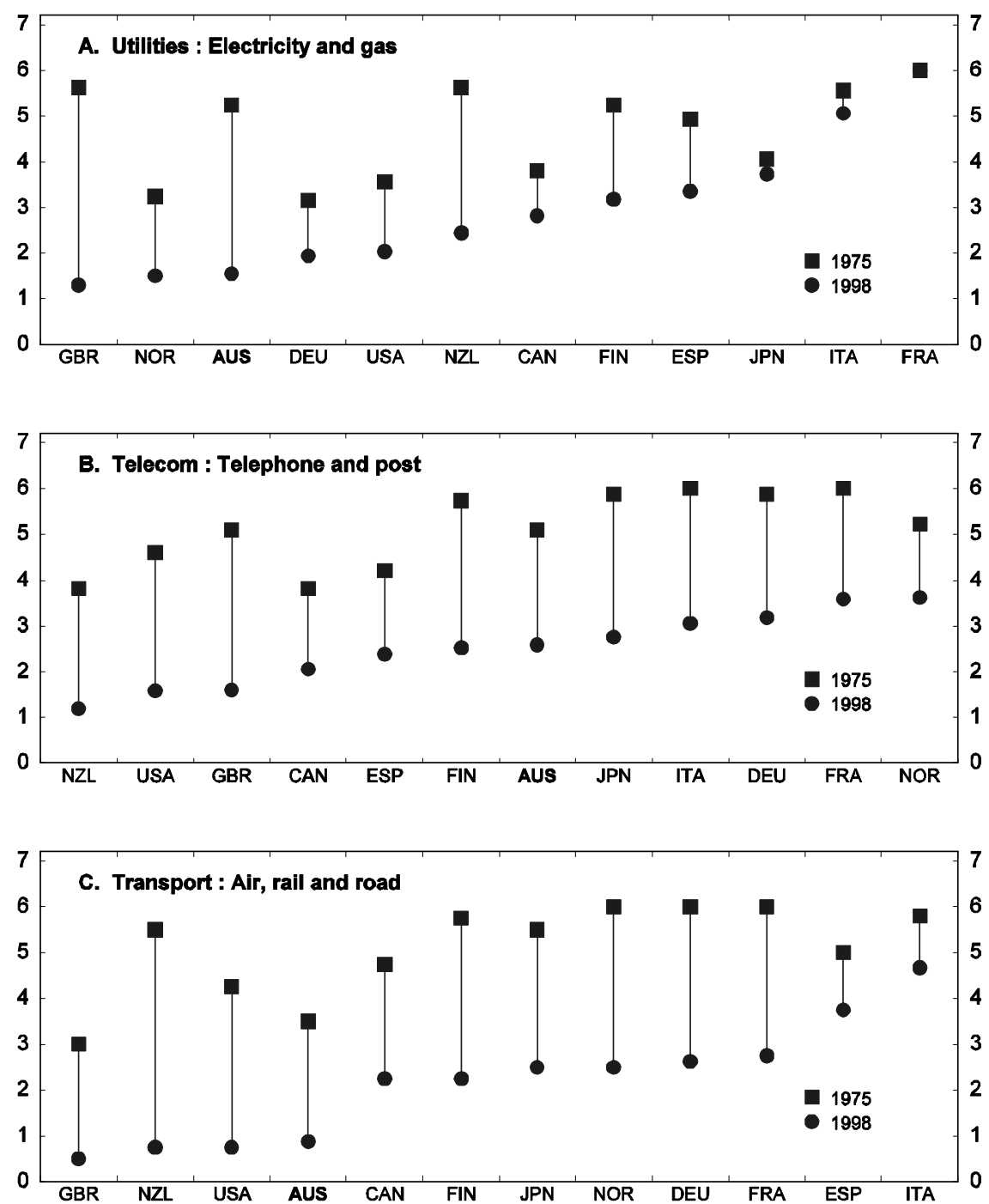

1. In each year and sector, the indicators have a 0-6 scale ranging from least to most restrictive of competition. They cover public ownership, barriers to entry, market structure, vertical integration and price controls. See Nicoletti and Scarpetta (2003) for details.

Source: OECD Regulatory Database.

9. A similar story can be told for a number of services industries during the 1990s, although these sectors were not direct targets of microeconomic reforms. In particular wholesale trade and finance and insurance, but also retail trade, construction and transport and storage became the new engines of the economy-wide strong overall productivity performance in the 1990s. Industry specific analyses, such as that of Johnston et al. (2000) for the wholesale sector ${ }^{15}$ provide evidence that general economic polices which have strengthened competition and sharpened incentives to be more productive have encouraged the introduction of new production processes and firm organisation and stimulated the rapid uptake of ICT in Australia. The rapid adoption of productivity-enhancing technologies was further helped by more flexible industrial relations arrangements which have improved work incentives by bringing remuneration closer into line with productivity. The more flexible industrial relations allowed the reduction of demarcations 
and the application of new organisational approaches, such as the introduction of multi-skilling, just-in-time delivery, split shifts, total quality control, team-based responsibility and quality circles. In addition, financial markets reforms had facilitated the access to and reduced the cost of funding for capital accumulation and for the diffusion of new technologies. And the removal of many (but not all) impediments to foreign direct investment (FDI) has encouraged FDI into Australia, and the resulting transfer of technology may also have helped to raise productivity. These findings at the sectoral level suggest that the acceleration in productivity growth in recent years is difficult to attribute to any single policy measure but is the likely outcome of a comprehensive set of microeconomic reforms, which combines competition policy, including trade policies, with reforms in labour and financial markets.

10. A set of indicators used to document links between competition policies (broadly defined) and aggregate economic performance has been developed at the OECD. These indicators provide a quantitative summary of the extent of barriers to trade and of administrative and economic regulations affecting competition. They suggest that over the past two decades or so, regulatory reform (as measured by both the absolute variation and the percentage decline in the regulatory indicator) was deepest in the United Kingdom, New Zealand, the United States and Australia. The indicators also reveal that at least since the late 1990s, Australia is quite open to competitive pressures, with only two other countries (the United Kingdom and Ireland) having lower obstacles to product market competition (Figure 7). These measures of competitive pressures (high scores indicating restrictineness) are inversely related to multifactor productivity growth, suggesting that the low barriers to market entry in Australia have contributed to its strong overall economic performance relative to most other OECD countries (Nicoletti and Scarpetta 2003). But in spite of the low overall degree of anti-competitive regulation, there is still potential for improvement. For example, the study by Scarpetta and Tressel (2002) suggests that in the case of Australia an alignment of the regulatory stance in each industry to best practice in the OECD area could reduce the gap in the level of multifactor productivity between Australia and the technological leaders in each industry by $7 \frac{1}{2}$ percentage points ${ }^{16}$ (Figure 8 ). Importantly though, this only accounts for one part of the productivity gap between Australia and the United States and suggests that there may be additional unexplored explanations for that gap. 
Figure 7. Indicators of product-market regulation ${ }^{1}$

$1997-98$

A. Overall indicator

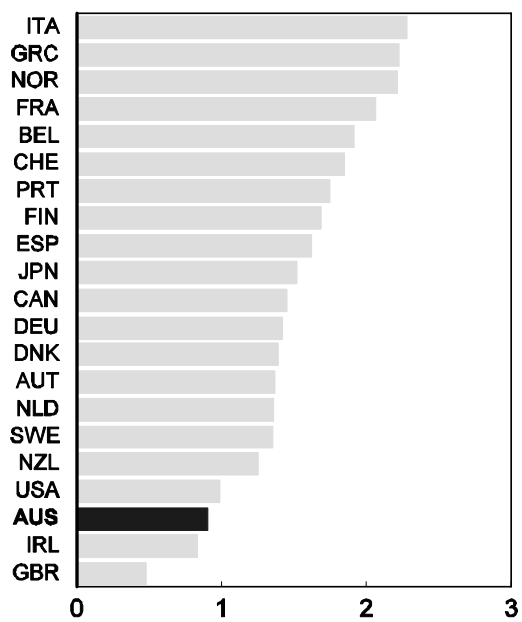

C. Barriers to entrepreneurship

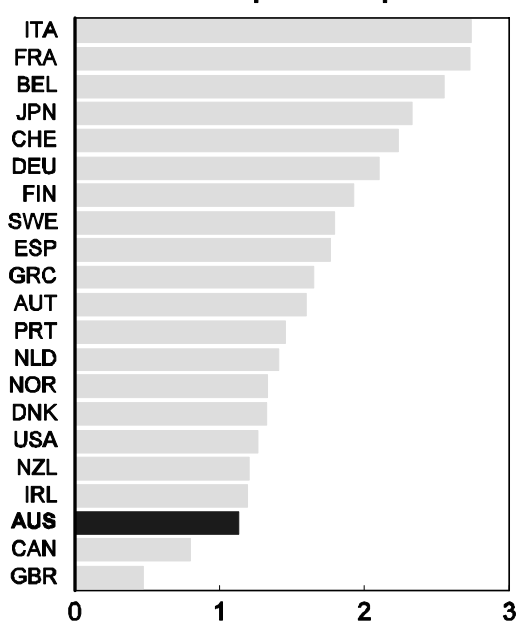

B. State control

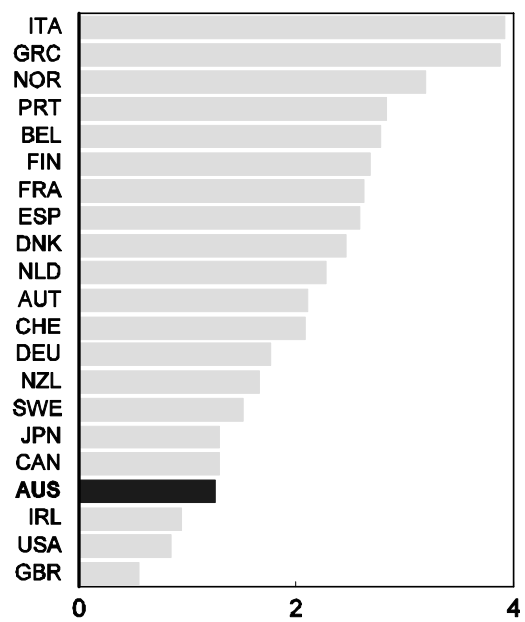

D. Barriers to trade and investment

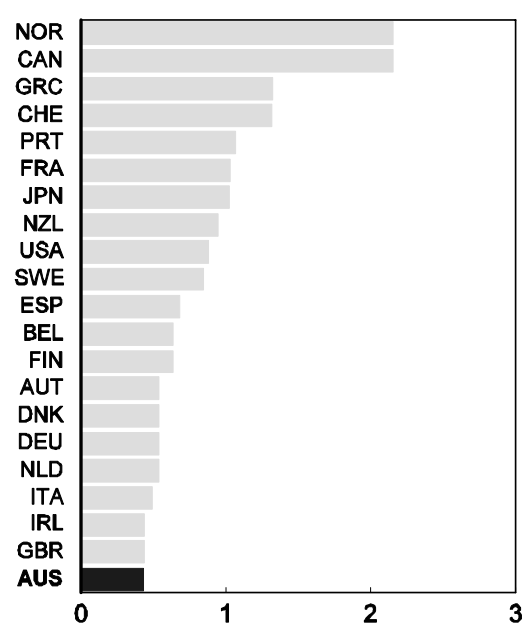

1. Synthetic indicators of strictness of legislation. Scores can range from 0 to 6 with higher values representing stricter regulation.

Source: Nicoletti, G., S. Scarpetta and O. Boylaud (2000), "Summary indicators of product market regulation with an extension to employment protection legislation”, OECD Economics Department Working Papers, No. 226. 
Figure 8. Effect of deregulation on the multifactor productivity gap relative to best practice ${ }^{1}$

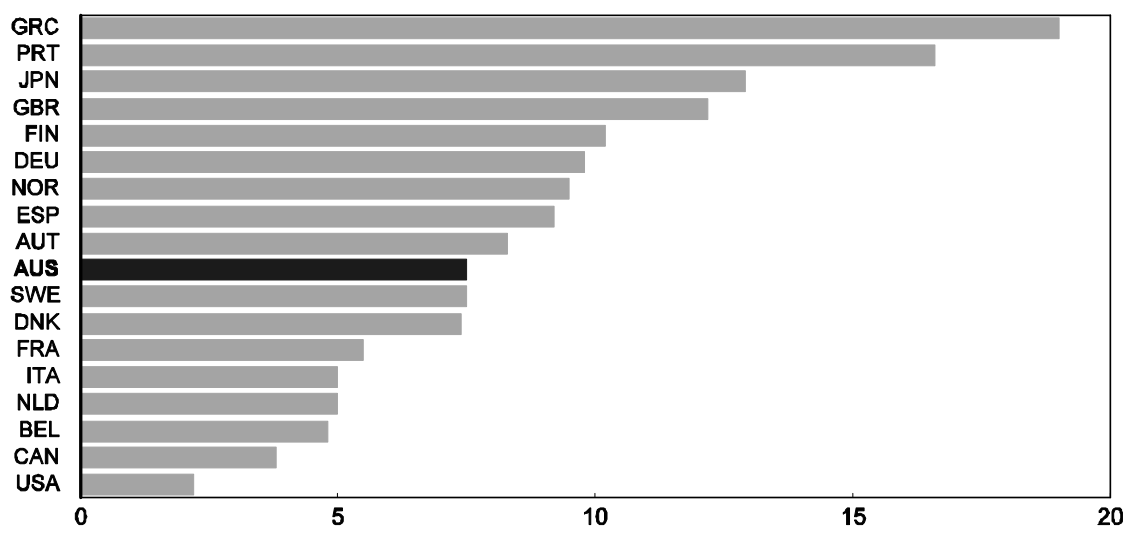

1. The graph shows the estimated effect of a decrease in product market regulation (PMR) by one standard deviation on the level of the long-term multifactor productivity (MFP) gap between a country and best practice abroad (the "leader"). The MFP gap is computed industry by industry and aggregated by taking an average weighted by the initial sectoral value-added.

Source: Scarpetta and Tressel (2002), "Productivity and convergence in a panel of OECD industries: do regulations and institutions matter?" OECD Economics Department Working Papers, No. 342.

\section{The intensity of product market competition is generally high}

11. An assessment of the intensity of product market competition is required to evaluate the scope for improving economic performance via stronger market discipline. However, the strength of product market competition can only be assessed on the basis of imperfect and ambiguous proxy measures, and even then, the data required do not exist for many countries. An indication of the overall intensity of competition in a country can be gleaned from international price comparisons, though these indicators need to be interpreted with caution. ${ }^{17}$ Part of the variation in aggregate price levels will tend to be positively related to variations in GDP per capita, ${ }^{18}$ and in evaluating price differences as indicators of competition pressures it is necessary to correct for this effect. Figure 9 shows that GDP price levels compared on the basis of PPPs and GDP per capita differ significantly across countries. For Australia, the corrected price level below the regression line suggests that there are competitive pressures at work which keep prices lower than expected on the basis of Australia's per capita income. This is confirmed by the recent study of Bradford (2003) which develops comparisons of domestic prices to world prices for 124 goods based on the prices collected by the OECD to compute purchasing power parities, which are converted to producer prices and adjusted for transport costs. Unfortunately, data availability (and the labour intensity of such calculations) limited the statistics to eight countries covering price quotes from 1991 to 1993. Although these measures are not perfect, the results, summarised for 29 industries in Table 3, indicate that Australia (with an "effective tariff", i.e. the percentage differential between domestic and world price, of 26.6\%) was a decade ago among the most open of the countries considered. In three sectors its price was the lowest of the eight countries and in thirteen of its industries it was one of the three lowest-priced countries. 
Figure 9. Relative price levels and GDP per capita

Real incomes and relative prices, 2002 in purchasing parities

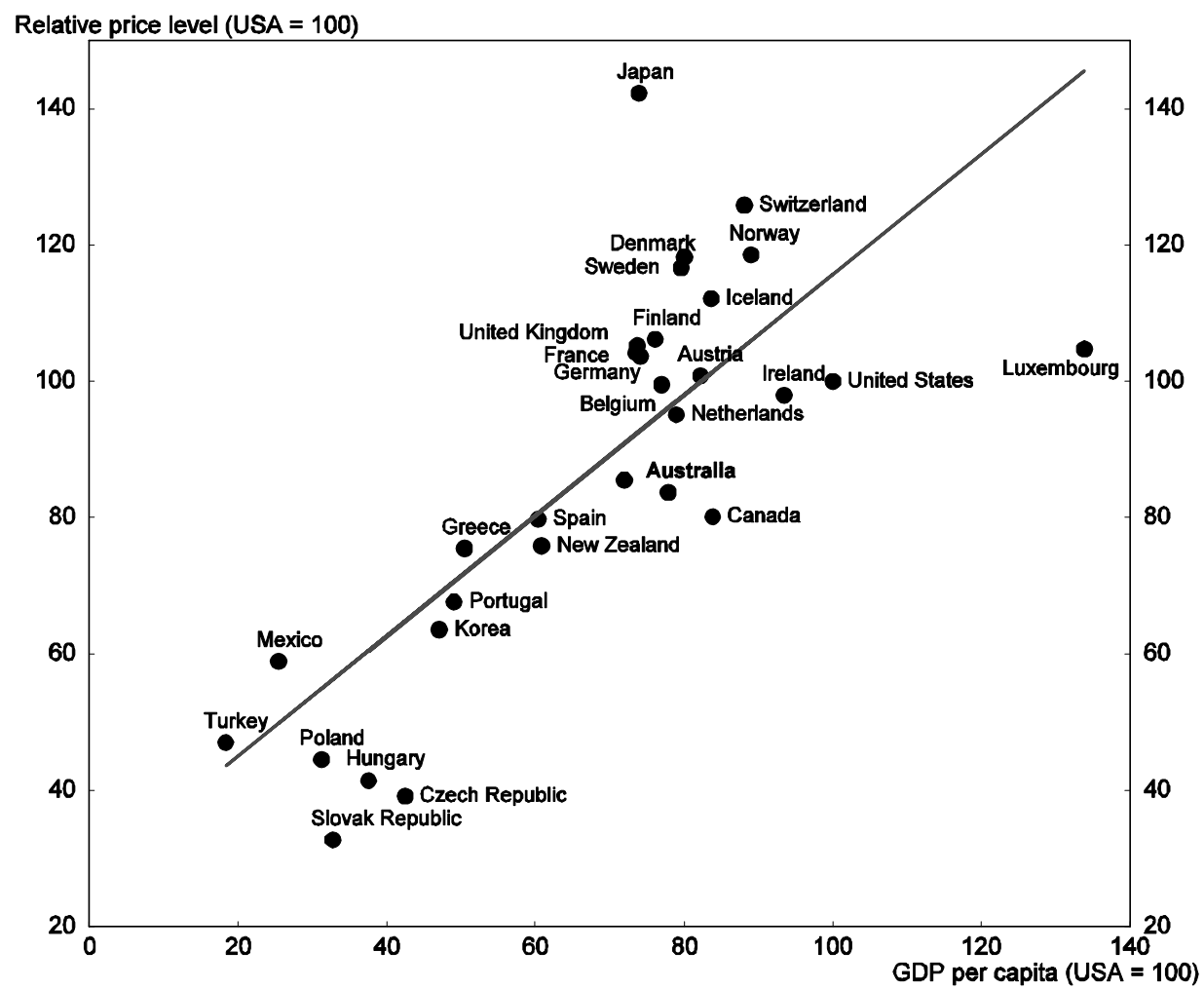

Source: OECD, Purchasing Power Parities. 
ECO/WKP(2005)38

Table 3. Ratio of the domestic to world price, 1991-1993

\begin{tabular}{|c|c|c|c|c|c|c|c|c|}
\hline Industry & Australia & Belgium & Canada & Germany & Japan & Netherlands & $\begin{array}{l}\text { United } \\
\text { Kingdom }\end{array}$ & $\begin{array}{l}\text { United } \\
\text { States }\end{array}$ \\
\hline Agriculture, fisheries and forestry & 1.067 & 1.157 & 1.112 & 1.529 & 1.584 & 1.080 & 1.648 & 1.158 \\
\hline Processed food & 1.086 & 1.372 & 1.192 & 1.447 & 2.099 & 1.299 & 1.202 & 1.090 \\
\hline Beverages & 1.447 & 1.444 & 1.535 & 1.765 & 1.540 & 1.328 & 1.694 & 1.061 \\
\hline Tobacco & 1.472 & 1.947 & 1.955 & 3.531 & 1.000 & 1.385 & 2.217 & 1.060 \\
\hline Textiles & 1.111 & 1.218 & 1.163 & 1.101 & 1.478 & 1.140 & 1.237 & 1.051 \\
\hline Apparel & 1.264 & 1.569 & 1.175 & 1.457 & 1.384 & 1.280 & 1.074 & 1.158 \\
\hline Leather and products & 2.944 & 1.777 & 1.236 & 1.437 & 1.329 & 1.658 & 1.168 & 1.143 \\
\hline Footwear & 1.657 & 1.823 & 1.415 & 1.328 & 2.289 & 2.239 & 1.027 & 1.111 \\
\hline Furniture and fixtures & 1.299 & 1.958 & 1.558 & 1.392 & 2.707 & 1.471 & 2.172 & 1.020 \\
\hline Paper and products & 1.438 & 1.659 & 1.060 & 1.606 & 1.804 & 1.965 & 1.783 & 1.050 \\
\hline Printing and publishing & 1.120 & 1.310 & 1.205 & 1.024 & 1.186 & 1.342 & 1.029 & 1.005 \\
\hline Drugs and medicines & 1.001 & 1.692 & 2.680 & 2.643 & 1.217 & 3.349 & 1.845 & 3.105 \\
\hline Chemical products & 1.092 & 1.137 & 1.064 & 1.107 & 1.555 & 1.075 & 1.064 & 1.037 \\
\hline Petroleum and coal products & 2.127 & 3.375 & 1.320 & 2.847 & 3.359 & 4.335 & 4.067 & 1.007 \\
\hline Rubber products & 1.219 & 1.680 & 1.015 & 1.711 & 2.016 & 1.655 & 1.566 & 1.032 \\
\hline Pottery, china, etc. & 1.727 & 1.007 & 1.145 & 1.511 & 2.383 & 1.016 & 1.082 & 1.070 \\
\hline Metal products & 1.430 & 1.622 & 1.328 & 1.770 & 1.977 & 1.837 & 1.602 & 1.165 \\
\hline Office and computing machinery & 1.008 & 1.513 & 1.234 & 1.446 & 1.000 & 2.101 & 1.666 & 1.015 \\
\hline Machinery and equipment, nec & 1.343 & 1.682 & 1.297 & 1.325 & 1.559 & 1.527 & 1.388 & 1.175 \\
\hline Radio, TV and communication & & & & & & & & \\
\hline equipment & 1.178 & 1.558 & 1.204 & 1.298 & 1.226 & 1.432 & 1.236 & 1.034 \\
\hline Electrical apparatus, nec & 1.536 & 1.936 & 1.316 & 1.713 & 2.106 & 1.556 & 1.320 & 1.073 \\
\hline Shipbuilding and repairing & 1.278 & 1.267 & 1.107 & 1.354 & 1.200 & 1.545 & 1.536 & 1.000 \\
\hline Railroad equipment & 1.374 & 1.314 & 1.093 & 1.404 & 1.238 & 1.509 & 1.503 & 1.016 \\
\hline Motor vehicles & 1.224 & 1.351 & 1.197 & 1.315 & 1.000 & 1.648 & 1.680 & 1.106 \\
\hline Motorcycles and bicycles & 1.231 & 1.761 & 1.252 & 1.599 & 1.000 & 1.385 & 2.002 & 1.057 \\
\hline Aircraft & 1.191 & 1.199 & 1.082 & 1.282 & 1.020 & 1.462 & 1.454 & 1.001 \\
\hline Transport equipment, nec & 1.516 & 2.034 & 1.109 & 1.888 & 1.315 & 2.065 & 1.924 & 1.057 \\
\hline Professional goods & 1.125 & 1.571 & 1.082 & 1.379 & 1.077 & 1.369 & 1.586 & 1.074 \\
\hline Other manufacturing, nec & 1.237 & 1.807 & 1.209 & 1.863 & 2.348 & 1.636 & 1.416 & 1.030 \\
\hline Weighted geometric means & 1.266 & 1.555 & 1.270 & 1.539 & 1.567 & 1.541 & 1.480 & 1.118 \\
\hline
\end{tabular}

Source: Bradford (2003), "Paying the Price: Final Goods Protection in OECD Countries", Review of Economics and Statistics, Vol. 85.

12. The strength of competitive pressure also depends to a large extent on how exposed industries are to international competition. The increase in Australia's import penetration ratio (Figure 10, Panel A) over time in response to progressive relaxation of trade and investment barriers suggests that producers now face stronger competitive pressure from foreign firms than in the past. While the level of import penetration remains among the lowest of single OECD countries, when factors such as GDP per capita and geographic isolation are taken into account, Australia's level of import penetration is not significantly different to that which is expected. Strong international competition is also reflected in the record-low level of support for farmers, as measured by the OECD producer support estimates (Figure 11).- However, very strict quarantine and sanitary regulations can make access to the Australian market on agri-food products difficult. 
Figure 10. Indicators of market openness

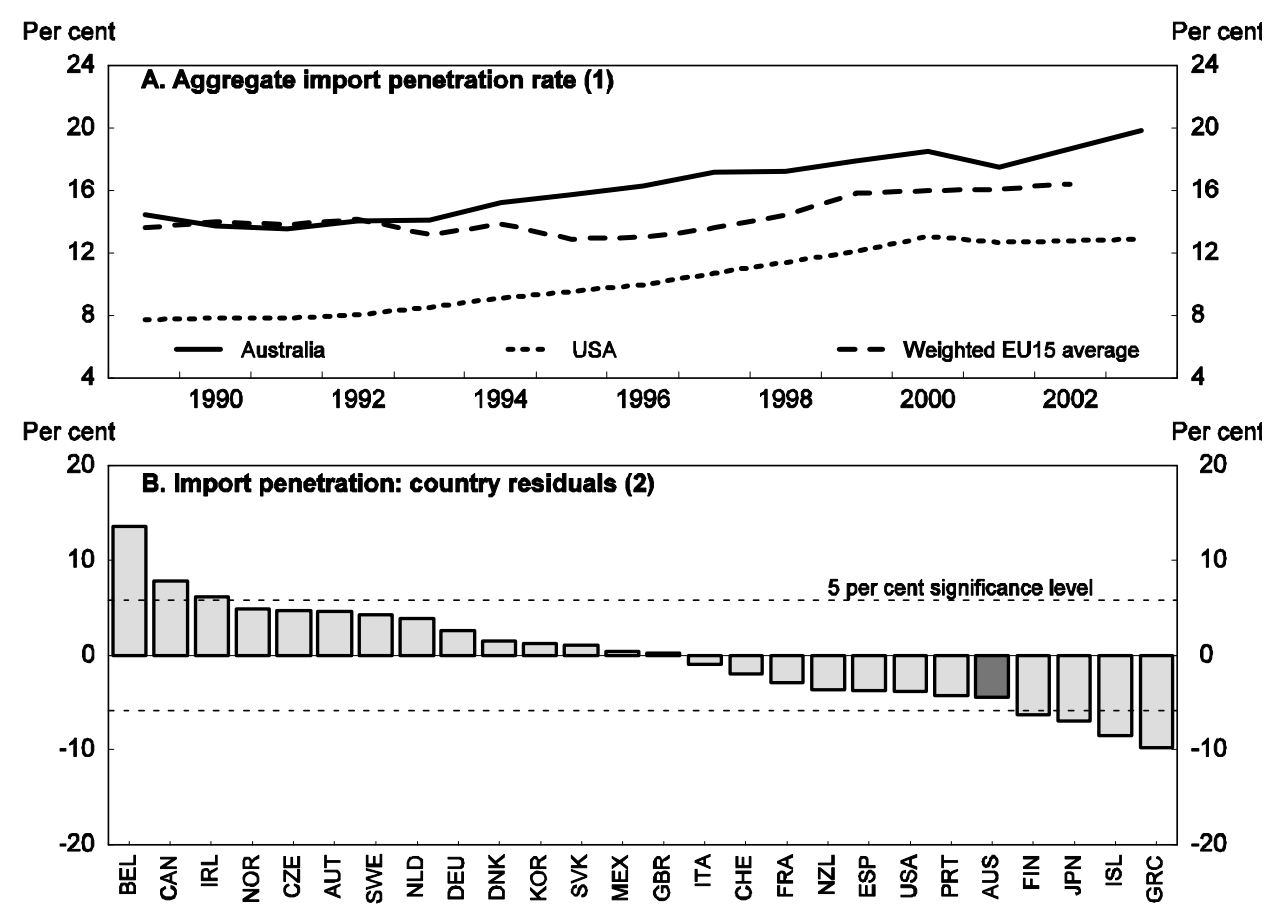

1. Imports of goods and services relative to imports plus gross domestic product, in real terms, excluding intra-EU trade.

2. Average residuals for the period 1995 to 2000 after controlling for effects of country size, gross domestic product per capita and transportation costs.

Source: OECD, Monthly Trade Statistics and OECD calculations. 
Figure 11. An international comparison of agricultural support

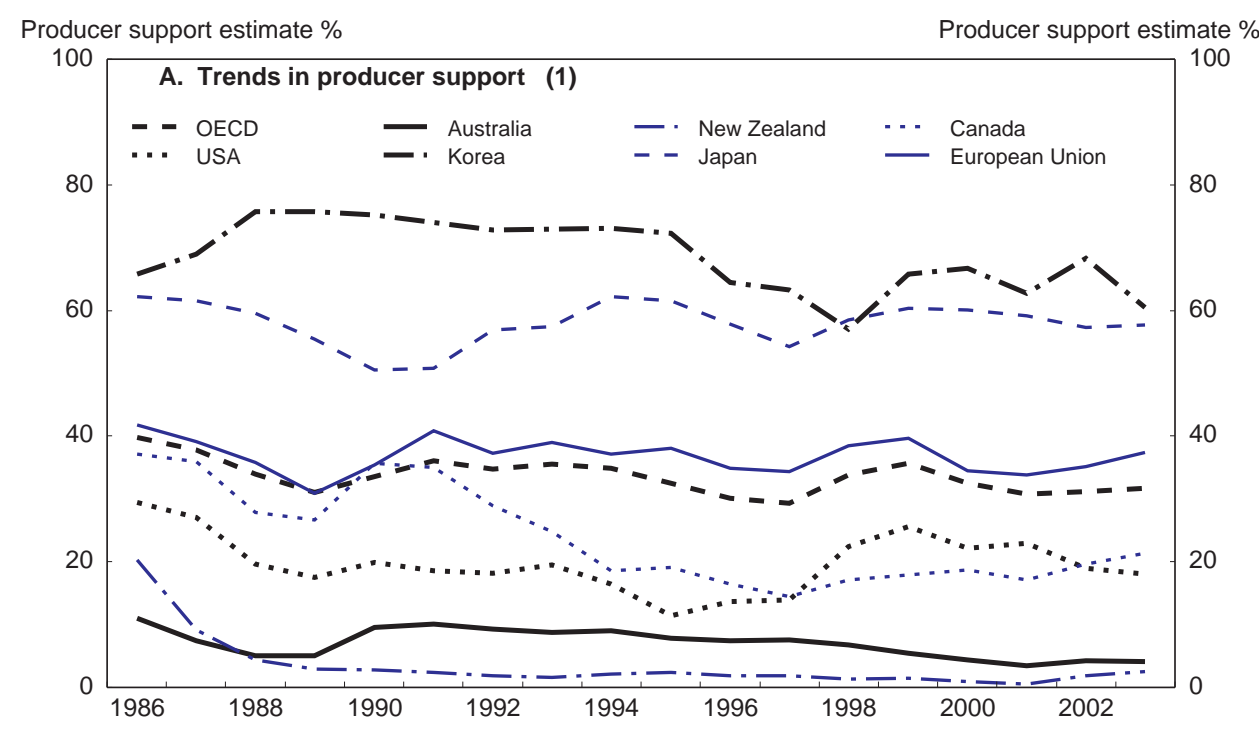

Nominal protection coefficient \% Nominal protection coefficient \%

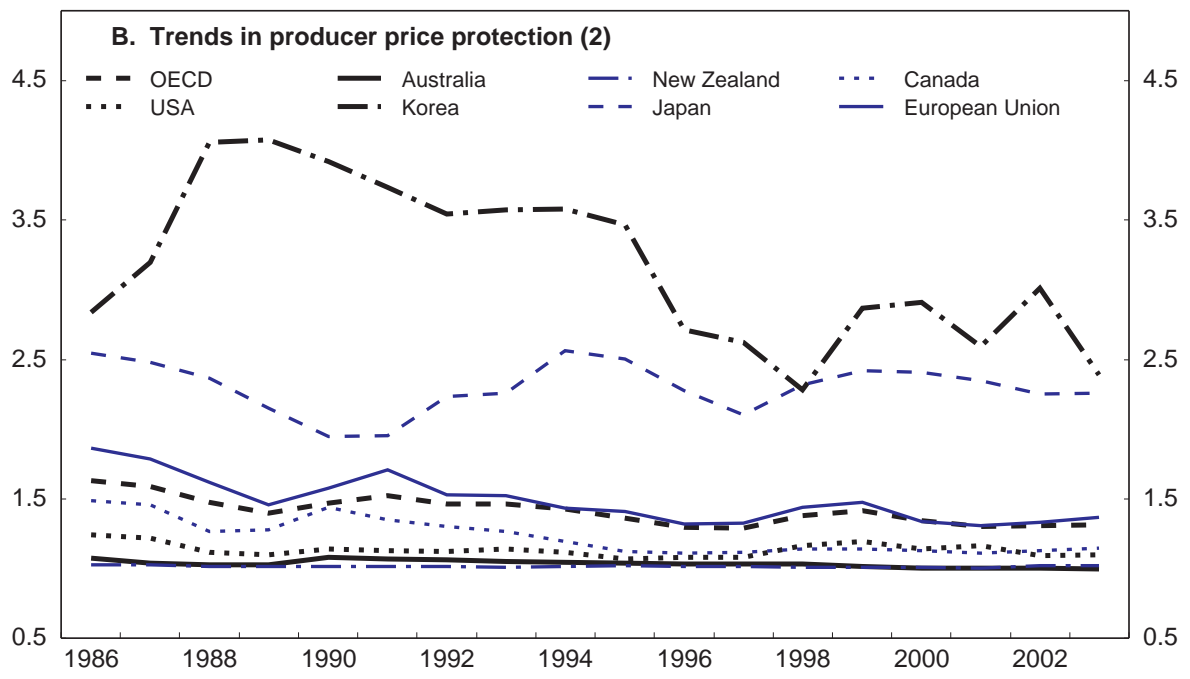

1. An indicator of the value of monetary transfers to agriculture resulting from agricultural policies. It is presented as a share of the total value of production at domestic producer prices.

2. The nominal protection coefficient (NPC) is a measure of market protection defined as the ratio between the average prices received by producers and border prices.

Source: OECD (2004), Agricultural Policies in OECD Countries at a Glance.

\section{Stronger competition has helped to improve the labour market performance}

13. A higher intensity of market discipline imposed on producers also tends to be reflected in a better overall employment performance (Box 2). This is supported by the research by Nicoletti et al. (2001), which found a significant effect of regulatory reforms on the employment rate in the business sector (excluding agriculture) of OECD countries even after controlling for the impact of various labour market indicators and the public-sector employment rate. ${ }^{19}$ The study's results are illustrated in Figure 12, which reveals that regulatory reform since the late 1970s has raised Australia's employment rate by more than 2 percentage points. 
Figure 12. Product market liberalisation and labour market performance
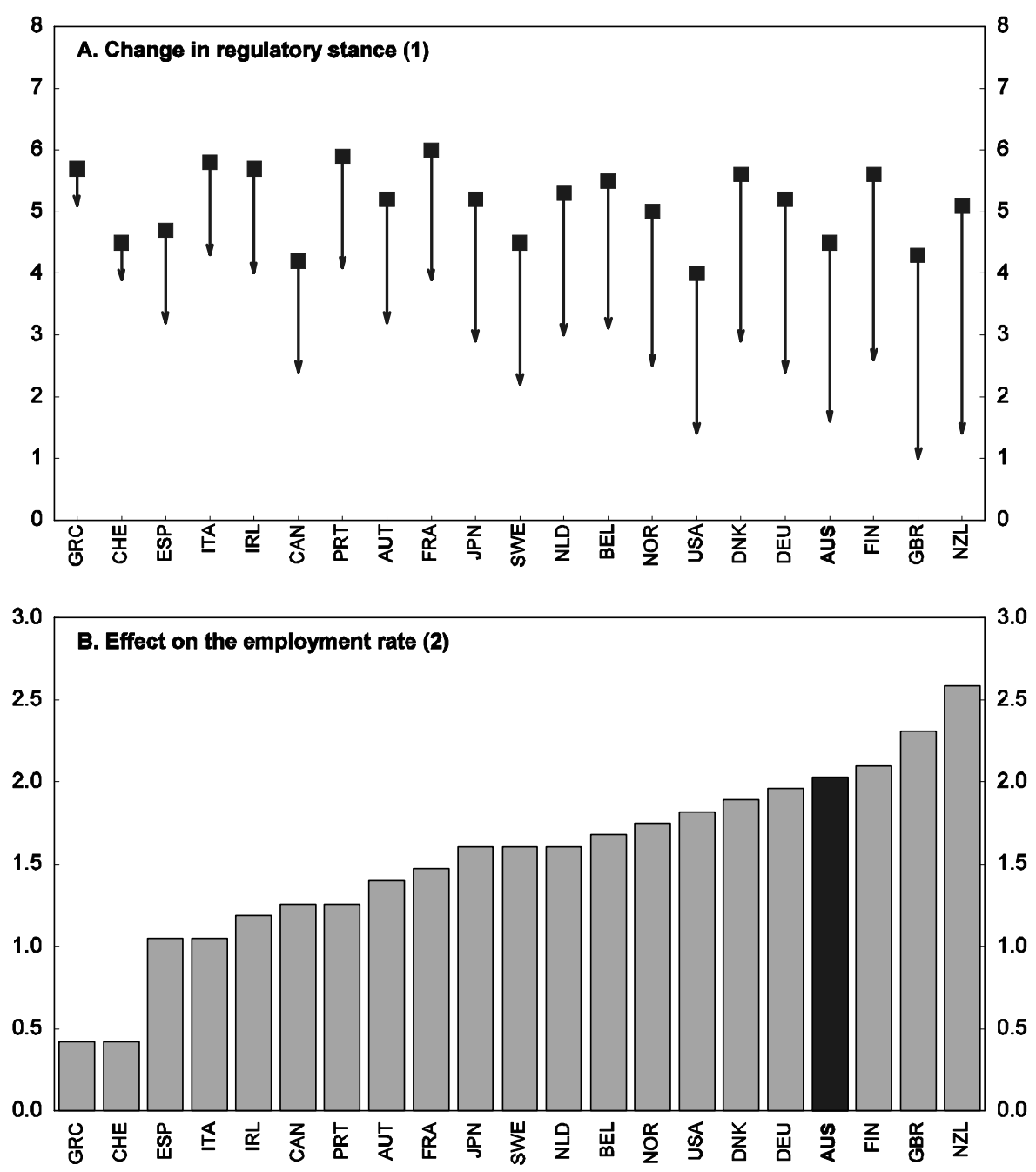

1. Reports changes in the regulatory stance in seven non-manufacturing industries (gas, electricity, post, telecommunications, passenger air transport, railways and road freight) between 1978 and 1998 . The regulatory stance is measured by a synthetic indicator ranging between 0 (least restrictive) and 6 (most restrictive).

2. Estimated contribution to the change in the non-agricultural business sector employment rate.

Source: Nicoletti, G. A. Bassanini, E. Ernst, S. Jean, P. Santiago and P. Swain (2001, "Product and Labour Market Interactions in OECD countries", OECD Economics Department Working Papers, No. 312. 
ECO/WKP(2005)38

\section{Box 2. The effects of product market reforms on employment and unemployment}

At the macroeconomic level, an increase in product market competition that leads to lower profit mark-ups over factor cost will unambiguously raise aggregate labour income. The division of the added labour income between higher real wages and employment gains (and hence lower unemployment) will depend on the flexibility embedded in labour market institutions. With the degree of flexibility in the Australian labour market having increased through industrial relations reforms since the mid-1980s, the gains from stronger competition in product markets is likely to have contributed to the observed employment gain.

However, stronger product market competition can also improve the functioning of the labour market in other ways. Insofar as wage premia are reduced in some sectors, frictional unemployment is likely to decline as incentives would be weaker to prolong spells of joblessness in anticipation of being hired into high-premia sectors. Smaller wage premia would also reduce artificially high unemployment benefits for displaced workers from high-premia sectors (due to benefits being related to previous wages), thus encouraging such workers to accept jobs elsewhere in the economy. Finally, the competition-induced increase in aggregate real wages may encourage labour force participation.

\section{Competition legislation and enforcement}

14. The past decade of strong economic performance has coincided with vigorous competition law enforcement and reform of the regulatory system (See Annex A1). Firms were challenged to control costs better, as increasingly effective application of Australia's competition law, the Trade Practices Act (TPA), reduced their power over price, and reforms under the National Competition Policy (NCP) reduced protections and restraints from regulation and state intervention. In part due to the high profile of enforcement and the reform programmes, the value of protecting and promoting competition appears to have broad public support. Competition policy is a prominent issue in public debate. But the programme has encountered resistance, too.

15. The Dawson Committee was created to review the competition provisions of the Trade Practices Act 1974 (TPA), and their administration. The Dawson Review concluded that the competition provisions of the TPA have served Australia well and reemphasised the importance of applying competition principles more broadly across the economy. The provisions of the TPA should not be regarded as a means of preserving particular companies; rather they should preserve the competitive process. Since the Dawson Committee reported however, recent cases involving the application of section 46 of the TPA have reopened debate about regulating for market power. Most of the recommendations made by the Dawson Committee focussed on improving existing processes by providing greater accountability, transparency and timeliness in decision making. Most of the Dawson Committee's recommendations, and the government proposals to implement them are now under consideration. The following paragraphs characterise the issues involved in this review.

16. Under the current merger clearance system, there is no formal requirement to notify proposed mergers or obtain approval in advance, so parties may proceed but at their own risk of violating the TPA's prohibition of mergers that substantially lessen competition. In practice, parties often approach the ACCC informally to determine its likely enforcement position and to negotiate changes to their plans to overcome the ACCC's objections. The ACCC has recently amended its informal merger clearance process to provide greater transparency and accountability. This informal process resembles the merger review process in some other Members, notably Japan and Korea. Although such informality can be efficient, it can also appear unaccountable. To make the ACCC's actions and reasoning more transparent, the Dawson Review recommended the introduction of a voluntary formal process for merger clearance. That is, parties would provide notice by application, and the ACCC would be obligated to respond as to the validity of the 
application and reasons for accepting or rejecting the proposal within a specified time period. Further, if the ACCC indicated that it thought the proposed merger would violate section 50 of the TPA, Dawson recommended that the applicant could appeal to the Australian Competition Tribunal. This procedure is a promising and potentially efficient alternative to mandatory pre-merger notification (which is not under consideration).

17. A distinctive feature of Australia's competition law is the provision for merger authorisation on grounds of public benefit. Currently, the ACCC considers applications for merger authorisation, however, the Dawson Committee recommended that the question of authorisation for mergers be submitted directly to the Australian Competition Tribunal, without prior consideration by the ACCC and without the possibility of a further substantive appeal (except on legal grounds). Three grounds are given: to avoid strategic appeals by third parties, to speed up the process so as to provide commercially viable timeframes for business (particularly for publicly listed companies), and to avoid having the issue of the public benefit decided by the same body that has examined the competitive effects. There may be risks that a one step authorisation process by the Australian Competition Tribunal will mean insufficient consideration is initially given to competition issues. Delay can be corrected by setting a deadline, for merger authorisations as well as for other authorisation decisions. Combination of responsibility for competition and public benefit issues characterises all ACCC authorisation decisions, not just mergers. That said, the Tribunal already considers public benefit issues, because it decides appeals from ACCC decisions about authorisation. Though the Tribunal is not as well resourced as the ACCC, the Dawson amendments provide that the ACCC will be able to assist the Tribunal in making its decision by providing investigative and other expertise. The members of the Tribunal all serve part-time and consistent with statutory obligations have varied expertise. While the Presidential member of the Tribunal must be a member of the Federal Court, the other nine members of the Tribunal are required to come from a diverse background of industry, economics, commerce, law and public administration.

18. Mergers that have indirect or cumulative effects on competition are harder to control. Controversies in Australia have focused on "creeping acquisitions" in the retail sector, producing large long-term changes in tiny increments. The ACCC has also been concerned about vertical acquisitions in network industries that may have effects in markets other than the one directly involved in the transaction. Because the statutory prohibition focuses on the individual transaction, it may be hard to deal with such combined or indirect effects. However, the Dawson Committee considered the issue of regulating for creeping acquisitions and did not recommend any change. The Dawson Committee found that section 50 adequately deals with competition issues, including those that might emerge over time from an accumulation of market power. The "substantial lessening of competition" standard is probably broad enough to be applied to these problems.

19. There are proposals to substantially increase sanctions, including those to strengthen deterrence against horizontal price fixing. The basic sanction against violation is a civil financial penalty, imposed by a court in an action brought by the ACCC. The maximum civil fine against a corporation is A $\$ 10$ million; against an individual, $\mathrm{A} \$ 500$ 000. In practice, the biggest fines to date, for price fixing of power transformers, totalled $\mathrm{A} \$ 35$ million against all parties and included fines against 11 individuals ranging from $\mathrm{A} \$ 35000$ to $\mathrm{A} \$ 150000$. The cap on these fines is to be modified in order to permit larger fines against larger-scale violations. Rather than a fixed number or percentage, the cap on corporate fines will be the greater of $\mathrm{A} \$ 10$ million, 3 times the gain from the violation or, where the gain cannot be readily ascertained, 10 per cent of group turnover. These levels would make Australia's theoretical sanctions consistent with practices today in other major jurisdictions.

20. Individual fines are already common in cartel cases in Australia, but they are typically well below the ceilings. The average individual fine imposed since 1999 was A 45 500. The Dawson Committee's additional recommendations to tighten the effect of the civil sanctions against individuals, by prohibiting 
indemnification and providing for the prohibition of individuals from serving as directors or being involved in management, could also be useful. More fundamentally, the Dawson Committee endorsed developing a criminal penalty against hard-core price fixing and bid rigging subject to finding solutions to key difficulties in introducing such penalties in the Australian legal system. As noted below, the government has accepted this recommendation in principle and is considering how it could be implemented. Many jurisdictions are concluding that effective deterrence against this kind of misconduct requires a credible threat of criminal penalties. Resort to criminal process raises substantial legal complications that must be resolved. In Australia, these include the definition of the "serious cartel behaviour" that will be subject to the new sanction and devising a workable method of combining a clear and certain leniency policy with a criminal enforcement regime that is applied through other institutions. The ACCC has had a formal leniency programme since 2003, whose promise of reduced civil fines has yielded some enforcement successes. Assurance that the first executive to confess to the cartel will stay out of jail could yield even more.

21. The treatment of market power and the strategies of large or dominant firms has been a source of some controversy. Most of this controversy was generated in private lawsuits brought by smaller competitors, customers or suppliers. ${ }^{20}$ Even though only a small number of these lawsuits have been successful, the law has generally been applied in an economically sound way. It has sometimes been argued that the application of law in these cases could make it more difficult to use the law to achieve economically sound results in public enforcement actions. Having considered some of these controversies, the Dawson Committee recommended no changes in the substantive tests or powers in this area. The long-standing conundrum, whether liability for a dominant firm's misuse of its market power should depend on its "purpose" or on its "effect", is no longer considered important. However the test is phrased, sensible enforcement requires considering the market context. Further clarification about the characterisation of market power and the significance of market context in the relevant provision (section 46), would have a greater impact in helping the courts avoid any unintended effects. Such a clarification will be provided by the amendments announced in June 2004. These amendments will ensure that the leveraging of substantial market power for an illegal purpose will be characterised as an abuse of market power. They will also enable market context, such as agreements between firms that boost market power, to be taken into account. A reform proposed by the Dawson Committee to help small businesses implicitly recognises that context matters in assessing whether conduct can affect the degree of competition. As the law currently stands, small businesses can join together to negotiate collectively and may seek authorisation on public benefit grounds, since their collective negotiations would otherwise violate the TPA. In recognition that collective negotiation by small business may often do little to impair competition, the Dawson Committee recommended, and the Government accepted, a more streamlined and less costly notification process for such conduct, providing immunity as soon as a statutory time period has passed. Because the system could be abused, the ACCC will be able to revoke the immunity should the conduct not generate a net public benefit.

\section{The National Competition Policy}

\section{The reform framework}

22. The experience of the 1980s suggested that the costs of many government enterprises, which dominated infrastructure services, were inflated by excessive capital investment and over-manning and that the goods and services produced by these businesses often did not meet the standards sought by users. State and Territory governments had responded with their own reform agendas, but there was growing concern that a fragmented approach would lead to sub-optimal results. Accordingly, Australia's nine governments agreed in April 1995 to a far-reaching programme of competition policy reform - the National Competition Policy (NCP). As a basic principle, the NCP followed the recommendation of the Independent Committee of Inquiry ${ }^{21}$ (the "Hilmer Committee") in 1993 to apply the Trade Practices Act 1974 (TPA) - 
Australia's main competitive policy statute - to virtually all areas of the economy. This extended the reach of the TPA's prohibitions of anti-competitive conduct to all government businesses and unincorporated enterprises engaged in intrastate commerce. In general, NCP brought together many elements of a broader programme of economic reform which already began in the early 1980s. Other features of this broader programme included the dismantling of trade barriers, deregulation of the financial system, changes to labour market regulations, taxation reform, and more recently, widespread changes to funding and delivery arrangements for various government services.

23. The Council of Australian Governments (COAG) is in charge of the national co-ordination of the NCP reform objectives and assessment benchmarks, while Commonwealth, States and Territories are responsible for implementing major elements of the NCP. Although the States and Territories are responsible for significant elements of $\mathrm{NCP}$, much of the direct financial return accrues to the Commonwealth through higher taxation revenue from increased economic activity. Accordingly, the Commonwealth government provides competition payments to the State and Territory governments to redistribute the gains (totalling around $\mathrm{A} \$ 5$ billion over nine years). However, in order to receive full competition payments, States and Territories must achieve satisfactory progress in terms of the agreed reform agenda. The National Competition Council ${ }^{22}$ (NCC), which was established by the Competition Policy Reform Act ${ }^{23}$ 1995, assesses whether jurisdictions have met their obligations to implement the National Competition Policy and related reforms in gas, electricity, water and road transport, and makes recommendations on competition payments to the Australian Government Treasurer. Governments are entitled to choose not to implement all elements of the National Competition Policy, but in doing so may not receive full competition payments. A weakness of the "payments-leverage approach" to encouraging compliance with the NCP reform framework is the lack of incentives for compliance (or of sanctions for non-compliance) at the Commonwealth government level, apart from the opprobrium of being found not to comply.

\section{Legislation review}

24. The legislation review and reform programme is a vital element of the NCP. It obliges governments to examine and, where it is in the public interest, reform all existing legislation that restricts competition. It is directed to achieving better regulation, not necessarily less regulation. The guiding principle of the review is that legislation should not restrict competition unless the benefits of such restriction outweigh the costs and the objectives of the legislation can only be achieved by restricting competition. New legislation must also meet these principles. The NCP further obliges governments to undertake a legislation review at least every ten years.

25. In mid-1996, governments undertook to review by mid-2002 (extended to mid-2003), around 1 800 separate pieces of Commonwealth and State legislation which had been identified as containing restrictions on competition. In part because of the enormous scope of the task, but also reflecting opposition from the groups that benefit from protection, no jurisdiction managed to complete its review and reform activity at 30 June 2003. The areas of restriction seen to most impact on competition throughout the process have been water management, primary industries, communications, fair trading and consumer protection, insurance and superannuation, health, legal and other professions, pharmaceuticals, planning and construction, retailing, social regulation and transport. These priority areas account for approximately 800 pieces of legislation. Altogether, substantial progress has been achieved. Australia-wide, around $70 \%$ of governments' nominated legislation has been reviewed and, where appropriate, reformed. For priority legislation, the rate of compliance is substantially lower, at around 56 per cent overall. However, much of the priority legislation review and reform activity still under way is expected by the NCC to be completed in the near future. 
26. A comparison of Australian governments' overall compliance illustrates the insufficient incentives for the Commonwealth to fully comply with the NCP. By mid-2003, the Commonwealth government completed the legislation review and reform of around half of its stock of legislation. It reviewed, and where suitable, reformed one-third of its priority legislation and two-thirds of its non-priority legislation. Excluding areas subject to ongoing interjurisdictional processes, the Commonwealth had 22 areas of non-compliance in priority legislation. ${ }^{24}$ Accordingly, the Commonwealth compliance rate was the second lowest of all Australian governments and not commensurate with its leadership role in other areas of the NCP.

\section{Infrastructure industry reforms}

\section{Access regime}

27. Major infrastructure facilities such as electricity grids, gas pipelines and some communications networks tend to be natural monopolies, that is, a single facility can meet market demand at less cost than two or more facilities. Hence, development of new facilities would be unnecessary and wasteful. Infrastructure owners can enjoy a strategic position in an industry because access to these facilities may be essential for businesses operating in upstream or downstream markets. Infrastructure operators can also seek to exploit their position by charging monopolistic prices to businesses using the infrastructure. This behaviour can harm competition in related markets and be detrimental to consumers. An access regime is one means of restraining prices and maintaining output in these situations; other means would be direct monitoring and control of prices and service standards.

28. The NCP has established a National Access Regime for third party access to "essential" infrastructure services provided by facilities of national significance, affecting infrastructure assets of a value of well over A $\$ 50$ billion. The Regime gives economic entities the legal right to negotiate for the use of "essential" services provided by infrastructure operated by other businesses. It seeks to ensure that businesses are offered reasonable terms and conditions of access. In the event that the parties are unable to reach a commercial agreement, the Regime provides recourse to binding arbitration.

29. Since its introduction in 1995, the National Access Regime has proved to be an innovative, but also complex and often controversial piece of regulation. It has been examined by the Productivity Commission (2001b) with a view to ensuring that access regulation is better targeted and more workable, and to minimising the risk of access regulation deterring investment in essential infrastructure. In response, the Commonwealth government in 2004 proposed changes to the Regime designed to clarify its objectives and scope, encourage efficient investment in infrastructure, strengthen incentives for commercial negotiation and improve the certainty and transparency of regulatory processes.

\section{Electricity}

30. A competitive and efficient electricity industry is a key objective of the NCP (NCC 2003a), featuring a national wholesale electricity market and an interconnected national electricity grid. To support this objective, governments agreed to a range of reforms aimed at breaking down barriers to interstate and intrastate competition, including dismantling State-owned monopolies and implementing a third party access regime for transmission and distribution. As an important step, New South Wales, Victoria, Queensland, South Australia and the Australian Capital Territory (ACT) are now part of an interconnected national electricity market. Tasmania is due to join in 2005 on completion of a link to the mainland. Western Australia and the Northern Territory will not join the national electricity market because of the long distances between their load centres and the interconnected electricity network in eastern and southern Australia. Western Australia intends to disaggregate its electricity monopoly into generation, networks 
(transmission and distribution) and retail entities and to undertake other restructuring measures to provide for more competition in the market.

31. Following the reforms, there have been substantial improvements in the performance of the electricity industry participating in the national electricity market. The Australian Bureau of Agricultural and Resource Economics (ABARE) estimated ${ }^{25}$ that three years after the commencement of the national electricity market in December 1998, the benefits from electricity reform were equivalent to an increase in Australia's real GDP by A $\$ 1 \frac{1}{2}$ billion (2001 prices). ABARE predicts that electricity reform alone will raise Australia's real GDP in 2010 by $1 / 4$ per cent above what it would have been without reform. During the five years ending in 2003-04, electricity prices for households fell in real terms in all States participating in the national electricity market, except South Australia. ${ }^{26}$ Total savings made by all households across all capital cities in financial year 2000/01 were estimated at about A $\$ 70$ million. Among other benefits from reform have been greater reliability of supply and system security. Increased competitive pressures have no doubt contributed to keeping Australian electricity prices at the lower end of the OECD spectrum (Figure 13).

32. Although the majority of jurisdictions have satisfied their specific obligations under the current electricity agreements, the objective of a fully competitive national electricity market is yet to be realised. For instance, full retail contestability, a key commitment set out in the electricity agreements, has been introduced in jurisdictions at varying degrees only. By enabling customers to choose supplier, including generators, retailers and traders, retail contestability is an essential feature to provide the market depth needed for effective competition, which should lead to more efficient electricity prices, enhanced consumer choice and improved services. It should also improve the efficiency in electricity investment infrastructure through more accurate investment price signals. 
Figure 13. Electricity prices in industry and households ${ }^{1}$

Using PPPs
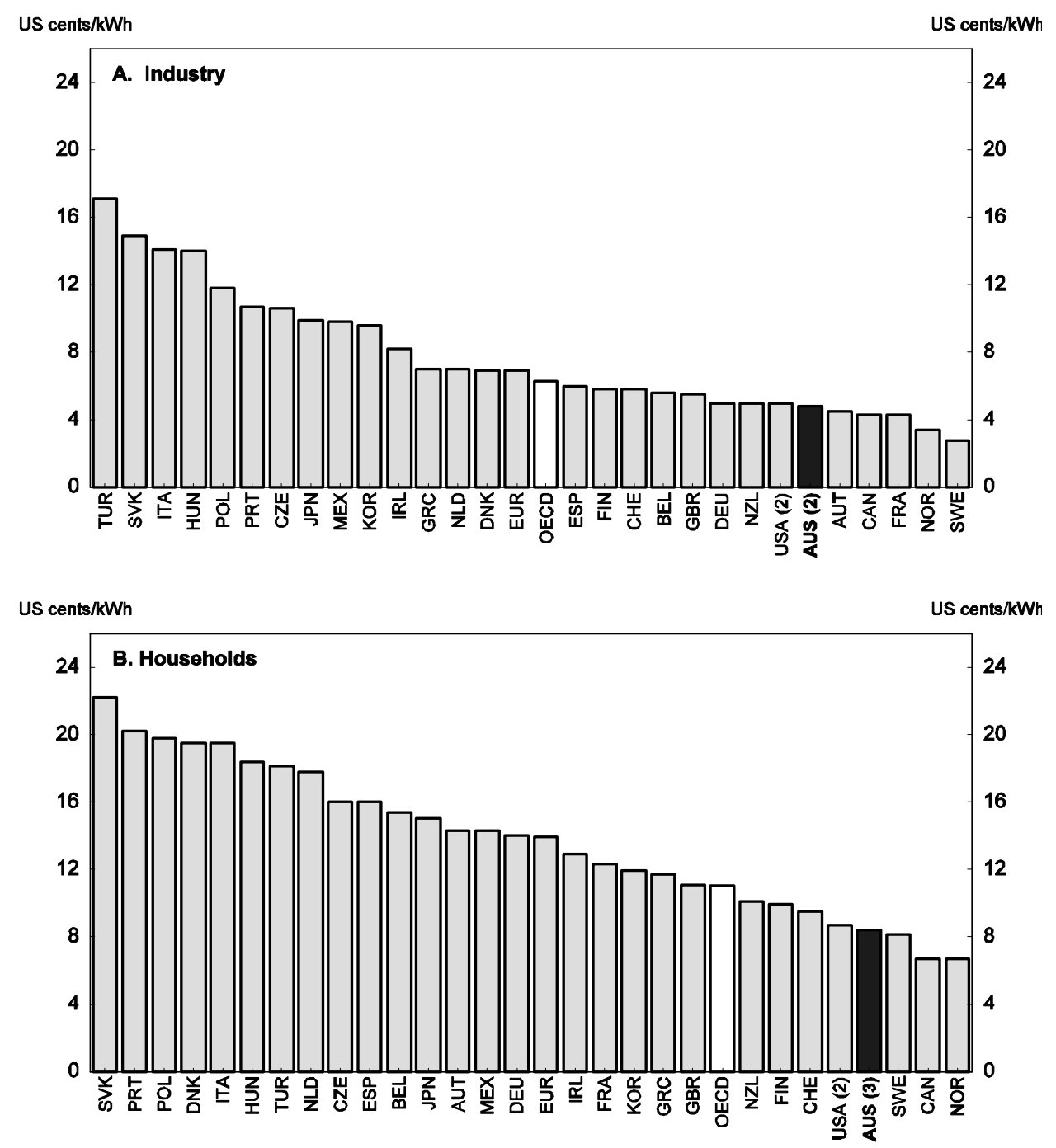

1. In 2003 or latest year available.

2. Price excluding tax.

3. Price excluding tax, prior to 2001.

Source: IEA (2004), Energy prices and taxes.

33. NCC (2003a) and other recent reviews, especially the COAG Energy Market Review (2002) have specified as most significant deficiencies of the current national electricity market to be:

- confused governance arrangements,

- too great a number of regulators and overlaps in regulatory responsibility, and

- perceived conflict of interest where governments are asset owners. 
34. This has contributed to inadequate interconnection and poor transmission arrangements which effectively regionalised the National electricity market and held back many of the benefits envisaged from a national market. To remove regulatory inconsistency arising from the existence of both State and national regulators in the energy sector, COAG agreed to establish a single Australian Energy Regulator (AER) on 1 July 2004, with initial responsibility for economic regulation of electricity wholesale and transmission networks and key rule enforcement functions. The responsibilities of the AER will be extended to gas in 2005 (see below) and by 2006, the AER will be in charge of the regulation of distribution and retailing (other than retail pricing) of energy, following the development of an agreed national framework. COAG also agreed to establish a new Australian Energy Market Commission (AEMC) on 1 July 2004. The functions of the AEMC will include rule-making (a more structured and transparent rule change process) and market development functions aimed at improving planning and cooperation at the national level. The AEMC will be a statutory commission and will replace the three bodies currently performing these functions. Although the new national regulatory bodies should help to reduce duplication, to clarify regulatory roles and lower the cost and complexity of regulation facing investors, clear government policy direction will be needed to develop a consistent regulatory framework.

Gas

- The programme of gas reform under the National Competition Policy comprises three elements:

- the structural separation of transmission, distribution, production and retail sectors of the gas industry;

- the introduction by all governments of third party access regulation for natural gas pipelines; and

- the provision for all gas consumers to choose their supplier, i.e. full retail contestability. ${ }^{27}$

35. The first two of these objectives have already been achieved. Barriers to full retail contestability were removed in most jurisdictions with the notable exception of Queensland which does not intend to implement it at all on account of a cost-benefit analysis which suggests that full retail contestability would impose significant net social costs. It thus is intended to introduce retail contestability only for large gas users (consuming more than 100 terajoules ${ }^{28}$ per year). Nevertheless, the reform's removal of restrictions on interstate trade in gas and provision of access to pipelines (transmission and distribution) and to customers (removal of exclusive franchises) has encouraged high investment in gas exploration, production, transmission and distribution in recent years. COAG (2002) noted in this context that the length of Australia's transmission pipeline system nearly doubled to over 17000 kilometres between 1989 and 2001.

36. However, as with the electricity sector, there is a need to consider the regulatory framework underlying the natural gas industry. Accordingly, the responsibilities of the new single national energy regulator will be broadened, to include the economic regulation of gas transmission as from 2005. The gas access regime is also likely to be amended -- following the Productivity Commission's Review of the Gas Access Regime (2004d) - with a focus on reducing the cost of regulation, promoting efficiency and encouraging investment in natural gas pipelines and in upstream and downstream markets. Further consideration will also need to be given how best to preclude states from exempting future arrangements for the joint marketing of natural gas from the competition rules of the Trade Practices Act. Other unfinished business includes the appropriate renewal of existing production licences and a review of the gas industry's principles for third party access to upstream gas processing facilities. 
37. Water supply and wastewater services are significant industries in Australia, with a combined value added of nearly one quarter of that of agriculture and almost three times that of the gas industry. ${ }^{29}$ More than 70 per cent of water use in Australia is in irrigation, with urban and industrial consumption also being significant. Excessive allocations to irrigation over most of the past century have caused extensive damage to river systems and groundwater resources, while salinity ${ }^{30}$ associated with rising water-tables is rendering infertile large tracts of productive land. In order to establish an efficient and sustainable water industry and to arrest the widespread natural resource degradation caused by water use, COAG agreed in 1994 to include in the NCP framework a fundamental reform of water policies with the objective of attaining a market based system in 2005 .

38. In 2004, COAG enhanced the water reform agenda to reflect improvements in knowledge since the 1994 agreement, and to address variations in progress with water reforms between regions and jurisdictions.

39. Full implementation of the 2004 National Water Initiative Agreement will result in a nationally-compatible, market, regulatory and planning based system of managing surface and groundwater resources for rural and urban water use and aim to achieve the following:

- clear characteristics for secure water access entitlements;

- transparent, statutory-based water planning;

- statutory provision for environmental and other public benefit outcomes, and improved environmental management practices;

- complete the return of all currently overallocated or overused systems to environmentally-sustainable levels of extraction;

- progressive removal of barriers to trade in water and meeting other requirements to facilitate the broadening and deepening of the water market, with an open trading market to be in place;

- clarity around the assignment of risk arising from future changes in the availability of water for the consumptive pool;

- water accounting which is able to meet the information needs of different water systems in respect of planning, monitoring, trading, environmental management and on-farm management;

- policy settings which facilitate water use efficiency and innovation in urban and rural areas;

- addressing future adjustment issues that may impact on water users and communities; and

- recognition of the connectivity between surface and groundwater resources and connected systems managed as a single resource.

40. The reform agenda is being supported by a substantial investment of Australian Government funding in areas previously largely left to the states, including water use efficiency in urban and rural environments, and the return of water to flow stressed river systems. 
41. An overview of progress made by jurisdictions with implementing the NCP water reform framework is given in Table 4.

Table 4. Status of jurisdictions' progress in implementing water reform components, as at May

\begin{tabular}{|c|c|c|c|c|c|c|c|c|c|}
\hline Reform & NSW & Vic & Qld & WA & SA & Tas & ACT & NT & $\mathrm{MDBC}^{f}$ \\
\hline \multicolumn{10}{|l|}{$\begin{array}{l}\text { Pricing } \\
\text { - } \text { urban }^{\mathrm{a}}\end{array}$} \\
\hline Full cost recovery ${ }^{b}$ & $\sqrt{s}$ & $\checkmark$ & $\sqrt{\mathrm{s}}$ & $\square$ & $\square$ & $\sqrt{s}$ & $\checkmark$ & $\checkmark$ & na \\
\hline Two-part tariff & $\sqrt{\mathrm{s}}$ & $\checkmark$ & $\sqrt{\mathrm{s}}$ & $\checkmark$ & $\checkmark$ & $\checkmark$ & $\checkmark$ & $\checkmark$ & na \\
\hline $\begin{array}{l}\text { Cross subsidies removed, others made } \\
\text { transparent } \\
\text { - rural water }\end{array}$ & $\checkmark$ & $\checkmark$ & $\checkmark$ & $\checkmark$ & $\checkmark$ & $\square$ & $\checkmark$ & $\checkmark$ & na \\
\hline Full cost recovery & $\square$ & $\square$ & $\sqrt{\mathrm{s}}$ & $\square$ & na & $\checkmark$ & na & na & $\square$ \\
\hline Two-part tariff & $\checkmark$ & $\checkmark$ & $\checkmark$ & $\square$ & na & $\checkmark$ & na & na & $\checkmark$ \\
\hline $\begin{array}{l}\text { Cross subsidies removed, others made } \\
\text { transparent }\end{array}$ & $\square$ & $\square$ & $\checkmark$ & $\square$ & $\square$ & $\checkmark$ & na & na & $\square$ \\
\hline $\begin{array}{l}\text { Investment appraisal (new rural schemes) } \\
\text { Entitlements and trading }\end{array}$ & $\checkmark$ & $\checkmark$ & $\checkmark$ & $\checkmark$ & $\checkmark$ & $\checkmark$ & $\checkmark$ & $\checkmark$ & na \\
\hline $\begin{array}{l}\text { Legislation separating water entitlements } \\
\text { from land title }\end{array}$ & $\checkmark$ & $\checkmark$ & $\checkmark$ & $\checkmark$ & $\checkmark$ & $\checkmark$ & $\checkmark$ & $\checkmark$ & na \\
\hline Licences converted / allocations defined & $\sqrt{\mathrm{s}}$ & $\sqrt{\mathrm{s}}$ & $\sqrt{\mathrm{s}}$ & $\checkmark$ & $\sqrt{s}$ & $\sqrt{\mathrm{s}}$ & $\checkmark$ & $\checkmark$ & na \\
\hline \multicolumn{9}{|l|}{ Environment $^{\mathrm{d}}$} & na \\
\hline Environmental allocations & & & & & & & & & \\
\hline Stressed and over- allocated rivers ${ }^{\mathrm{e}}$ & $\square$ & $\square$ & na & na & na & na & na & na & $\square$ \\
\hline Other systems surface / groundwater & $\square$ & $\square$ & $\square$ & $\square$ & $\sqrt{\mathrm{s}}$ & $x$ & $\checkmark$ & $\square$ & na \\
\hline Water quality management & $\sqrt{\mathrm{s}}$ & $\sqrt{\mathrm{s}}$ & $\square$ & $\square$ & $\sqrt{s}$ & $\sqrt{\mathrm{s}}$ & $\square$ & $\sqrt{s}$ & na \\
\hline Landcare practices (high value rivers) & $\checkmark$ & $\checkmark$ & $\checkmark$ & $\checkmark$ & $\checkmark$ & $\checkmark$ & $\checkmark$ & $\checkmark$ & na \\
\hline $\begin{array}{l}\text { Ecological appraisal (new rural schemes) } \\
\text { Institutional reform }\end{array}$ & $\checkmark$ & $\checkmark$ & $\checkmark$ & $\checkmark$ & $\checkmark$ & $\checkmark$ & $\checkmark$ & $\checkmark$ & na \\
\hline Separate roles & $\checkmark$ & $\checkmark$ & $\checkmark$ & $\checkmark$ & $\checkmark$ & $\checkmark$ & $\checkmark$ & $\checkmark$ & $\checkmark$ \\
\hline Holistic approach to resource management & $\checkmark$ & $\checkmark$ & $\checkmark$ & $\checkmark$ & $\checkmark$ & $\checkmark$ & $\checkmark$ & $\checkmark$ & $\checkmark$ \\
\hline $\begin{array}{l}\text { Integrated catchment management } \\
\text { approach }\end{array}$ & $\checkmark s$ & $\sqrt{s}$ & $\sqrt{s}$ & $\square$ & $\sqrt{s}$ & $\sqrt{s}$ & $\sqrt{s}$ & $\sqrt{s}$ & $\checkmark$ \\
\hline Commercial business focus & $\checkmark$ & $\checkmark$ & $\checkmark$ & $\checkmark$ & $\checkmark$ & $\checkmark$ & $\checkmark$ & $\checkmark$ & $\checkmark$ \\
\hline Performance comparisons & $\checkmark$ & $\checkmark$ & $\checkmark$ & $\checkmark$ & $\checkmark$ & $\checkmark$ & $\checkmark$ & $\checkmark$ & na \\
\hline $\begin{array}{l}\text { Irrigation scheme devolution of } \\
\text { management }\end{array}$ & $\checkmark$ & $\checkmark$ & $\checkmark$ & $\sqrt{s}$ & $\sqrt{s}$ & $\sqrt{s}$ & na & na & na \\
\hline Community consultation & $\checkmark$ & $\checkmark$ & $\checkmark$ & $\checkmark$ & $\checkmark$ & $\checkmark$ & $\checkmark$ & $\checkmark$ & $\checkmark$ \\
\hline
\end{tabular}

Note: The summary in the table is a broad indication of progress only. It does not purport to provide a complete picture of the details of reform implementation or of each government's compliance with the National Competition Policy water reform commitments.

a) Urban reforms include water and wastewater.

b) Full cost recovery requires governments to set prices so water and wastewater businesses earn sufficient revenue to ensure their ongoing commercial viability (the lower bound) but avoid monopoly returns (the upper bound). The lower bound of full cost recovery requires water businesses to recover, at least, operational, maintenance and administrative costs, externalities, taxes or tax equivalent regimes (not including income tax), the interest cost on debt, dividends (if any) and make provision for future asset refurbishment/replacement. The upper bound comprises operational, maintenance and administrative costs, externalities, taxes or tax equivalent regimes, provision for the cost of asset consumption and cost of capital (calculated using a weighted average cost of capital).

c) Rural water pricing commitments apply to government-owned irrigation schemes, government-owned bulk water suppliers, and commercial users (licensing charges for extraction of surface and groundwater using their own infrastructure). Progress in relation to licensing charges for commercial users is not reported in this table.

d) Jurisdictions established implementation programs in 1999 identifying river systems and groundwater resources (including stressed and overallocated river systems) for which they would complete programs to allocate water (including to the environment) by 2005 .

e) Jurisdictions were to demonstrate substantial progress in implementing their allocation programs by 2001, where progress includes at least allocations in all river systems which have been overallocated or are deemed to be stressed.

$\checkmark=$ implemented $\checkmark \mathrm{s}=$ substantially implemented ${ }_{\square}=$ implementing $\boldsymbol{x}=$ little or no progress na $=$ not applicable

f) Murray-Darling Bassin Commission.

Source: National Competition Council (2004). 
42. Of this programme, the urban water reform has made significant improvements. Most urban authorities have introduced consumption-based pricing of urban water to discourage wasteful use. In addition, full cost recovery by water service providers is largely achieved which helps to ensure appropriate investment in infrastructure. Institutional changes have been implemented to encourage efficiency in water provision and to make providers accountable for the quality and cost of water and sewerage services.

43. Rural water reform is much less advanced although all governments are establishing reform paths to institute efficient water pricing, ensure adequate water allocations to the environment, and to provide clear water property rights, separate from land title. Irrigators are charged for water use on a volumetric basis in many cases, and cross subsidies were either eliminated or have been made more transparent. Nevertheless, the price of water supplied to agriculture remains substantially less than that supplied to households. The development of water management arrangements, which allocate water among extractive uses and to the environment, is progressing, with priorities given to stressed and over-allocated systems. Where systems are stressed or over-allocated, governments are reducing the water available for extraction, or establishing arrangements which allow the possibility of future reductions. Australian governments have allocated funds for the compensation of farmers who see their extraction rights reduced. All jurisdictions are developing integrated catchment management frameworks and now have robust arrangements for examining proposals for new rural water infrastructure. ${ }^{31}$ However, water trading arrangements, based on a system of water access entitlements separated from land title, are not fully implemented. As yet, standardised trading contracts are not available and some states have restrictions on trading outside the irrigation district where the water is currently used. These constitute important barriers to effective trading. As a result, water trading - although expanding over time - is still in its infancy, with trading volumes applying mainly to temporary transfers.

44. With the completion of rural water reform by 2005 being very unlikely, substantial additional efforts are necessary to accelerate the implementation of the NCP water reform programme. Outstanding among the various unfinished complex tasks is the requirement to specify water rights appropriately, to make them enforceable and fully tradeable. ${ }^{33}$ For the unambiguous specification of water rights, better information on the volume and availability of water is needed, which will only be available when water management plans are fully implemented. Such water plans determine water allocation policies for a particular river system or groundwater basin, based on an assessment of environmental, social, cultural and economic considerations. They are critical to the certainty surrounding water access entitlements because they set out the current knowledge of the resource, parameters about the size of the consumptive pool and rules for allocating water to entitlement holders. In addition, enforceability of ownership rights calls for an effective registry system, and transferability requires water trading systems to operate efficiently. It is also important that the setting of environmental minimum flows in rivers where there has been over-allocation of water in the past does not jeopardise the successful introduction of trading. To obtain the full gains from more efficient allocation of water, barriers to trading between irrigation districts and states also need to be removed.

\section{Rail transport}

45. Rail transport accounted for around one-third of all domestic freight over the past 25 years. It has significantly changed character over the last decade or so, and its performance has improved. At the start of the 1990s the Australian rail system was characterised by (State-owned) integrated railways providing passenger and freight services in their respective jurisdictions. Since then all governments have implemented reforms. The Productivity Commission (1999c) lists several factors likely to have encouraged these reforms: 
- increased competition from road transport;

- $\quad$ persistent pressure on State Government budgets;

- pressure on railway freight rates from increasing competition in downstream markets; and

- the implementation of the National Competition Policy. ${ }^{34}$

46. Although all railways face similar problems, governments have adopted different solutions, reflecting that "one framework fits all" does not apply. Generally, reforms have included structural separation (both vertical and horizontal), the introduction of commercial disciplines (incorporation and privatisation) and arrangement for third party access to track infrastructure. As in many other countries, Australian railways have thus undergone landmark changes in aspects of their organisational structure, ownership and access arrangements over this period (Owens, 2003). Encouragingly, there have been improvements in the productivity of government-owned railways in providing freight and passenger services in Australia over the 1990s, leading to about 30\% decrease in freight rates in real terms. There is still scope for further improvements, though, as the level of technical efficiency ${ }^{35}$ remains $30 \%$ below the best performing countries. Freight rates ${ }^{36}$ on average in 1998 were still higher than in Canada and the United States, although lower than in most European countries and Japan.

47. The Australian government has made further progress in rail reform since the Productivity Commission's report of 1999, but challenges remain. The Australian government released its response to this report in April 2000, and has since then undertaken some initiatives in advancing rail reform which are consistent with the report's recommendations. Among these initiatives is the sale of government interest in National Rail Corporation Ltd., announced 31 January 2002, and thereby pursuing the Government's policy of not owning or operating rail services. In January 2004, the National Transport Commission (NTC) was established. This followed agreement by the Australian Transport Council to various recommendations from a consultant's Review of the National Road Transport Act 1991 (2002). The NTC's agenda is to push forward regulatory and operational reform for road, rail and inter-modal transport in order to deliver and sustain nationally consistent outcomes. Specifically, the Australian rail systems have perpetuated technical and other non-uniformities and inconsistencies that still have to be tackled (Australian Rail Industry: Overview and issues, 2003). There is also some evidence of dissatisfaction in the rail industry and among its customers with the outcomes from reform to date and the rates at which further improvements were planned (Status Report of the Progress of Rail Reform in Australia, 2001). Of all the reform issues examined in that report, there was most dissatisfaction with the progress of the national access and infrastructure pricing regimes, and the majority of stakeholders regarded the then current arrangements as poor.

48. In July 2003, the first complete three-year Strategic Plan of the National Transport Commission was presented (NTC, 2003). It was based on consultation with a broad range of stakeholders in transport regulatory reform from public and private sectors. It identifies initiatives for the indicative 2004/05 work programme that contribute to achieving the major national outcomes sought for the three years of the plan. These are safety, environment, efficiency, compliance and evaluation of implementation, maintenance and review. However, it fails to address the apparently widely held view among rail stakeholders that the system of competitive access has not succeeded in removing barriers to entry by third party operators. Such accusations deserve scrutiny. In the absence of barriers it could be argued that access pricing issues are purely a matter for commercial negotiations between infrastructure owners and access seekers. Hence, government intervention through the NTC, or any other body is not warranted. The current access regime is established under the CPA and operates generically for all natural monopoly infrastructure that falls within its scope. Still, the discontent by all stakeholders suggests that the framework is not working well. The main problem stems from the multiplicity of access regimes arising from separate State arrangements. 
To avert a major void in the process ahead, competitive access is a key reform principle, and a review of existing rail access arrangements should be launched.

\section{Road transport}

49. The road transport situation looks reasonably healthy. The aim now is to harmonise rules related to safety and operation since differences on these matters could be exploited to distort competition to some extent. Aiming to create a consistent national regulatory framework and focus, the National Road Transport Commission developed an initial national road transport reform package, comprising 31 initiatives in six modules: 1) registration charges for heavy vehicles; 2) transport of dangerous goods; 3 ) vehicle operations; 4) heavy vehicle registration; 5) driver licensing; and 6) compliance and enforcement. According to the 2003 NCC assessment, most states had completed all NCP road transport reform obligations at 30 June 2003, while the Commonwealth, Western Australia and the ACT were close to completing their reforms.

\section{Land transport}

50. On 7 June 2004 the Australian Government released its White Paper on its national land transport plan, AusLink. AusLink provides for a long-term, strategic approach to the planning and funding of Australia's national roads and railways, and outlines Australian land transport infrastructure funding for the next five years. AusLink's key objectives are to promote sustainable national and regional economic growth, development and connectivity by contributing to the development of an integrated national network. AusLink also seeks to meet significant forecasted growth in freight demand through the promotion of intermodal integration between all forms of transport. AusLink will be implemented through a cooperative intergovernmental process. Significant additional funding has been committed by the Australian Government to increase investment in national and inter-regional transport corridors, both road and rail, and improve intermodal transport links.

\section{Sea transport}

51. Australia's regulatory regime for ocean shipping conferences (Part X of the TPA) is currently under review by the Productivity Commission. This legislation provides limited, conditional exemptions from general competition law for liner conferences. The current review seeks to determine a preferred option for regulation of ocean shipping. The Productivity Commission has released a draft report for public consultation. The draft report suggests there is scope to enhance efficiency in this area through the repeal of Part $\mathrm{X}$ and applying general competition law to this sector, supported by appropriate transitional arrangements. If Part $\mathrm{X}$ is retained, the Productivity Commission recommends amendments to improve overall outcomes. Following consultation, the Productivity Commission will forward its final report and recommendations to the Australian Government in the near future. Coastal shipping reform also should be addressed.

\section{Air transport}

52. Against a background of significant market-structure changes, ${ }^{37}$ Australia's air market has recently been dominated by a major actor (Qantas) on trunk routes, but Qantas is increasingly being challenged by a second actor (Virgin Blue) which has gained a 30\% share of traffic on major routes. A new low-cost Qantas subsidiary Jetstar has entered leisure markets. In this environment discount air prices have fallen (Figure 14) and standard economy and business class fares have been stable. Nonetheless, economic theory and practical experience suggest that duopoly is not inherently stable, and continuing vigilance is desirable to detect any emergence of tacit collusion. Granting cabotage rights to foreign carriers flying into Australia and continuing to open Australia to investment cabotage could continue to reduce the risk of tacit 
collusion. Investment cabotage has added considerable flexibility to the aviation market, as has been demonstrated by the ability of Virgin Blue, which was then majority foreign owned, to respond to the collapse of Ansett, Australia's second major carrier.

Figure 14. Real domestic air fares excluding taxes and charges, monthly index

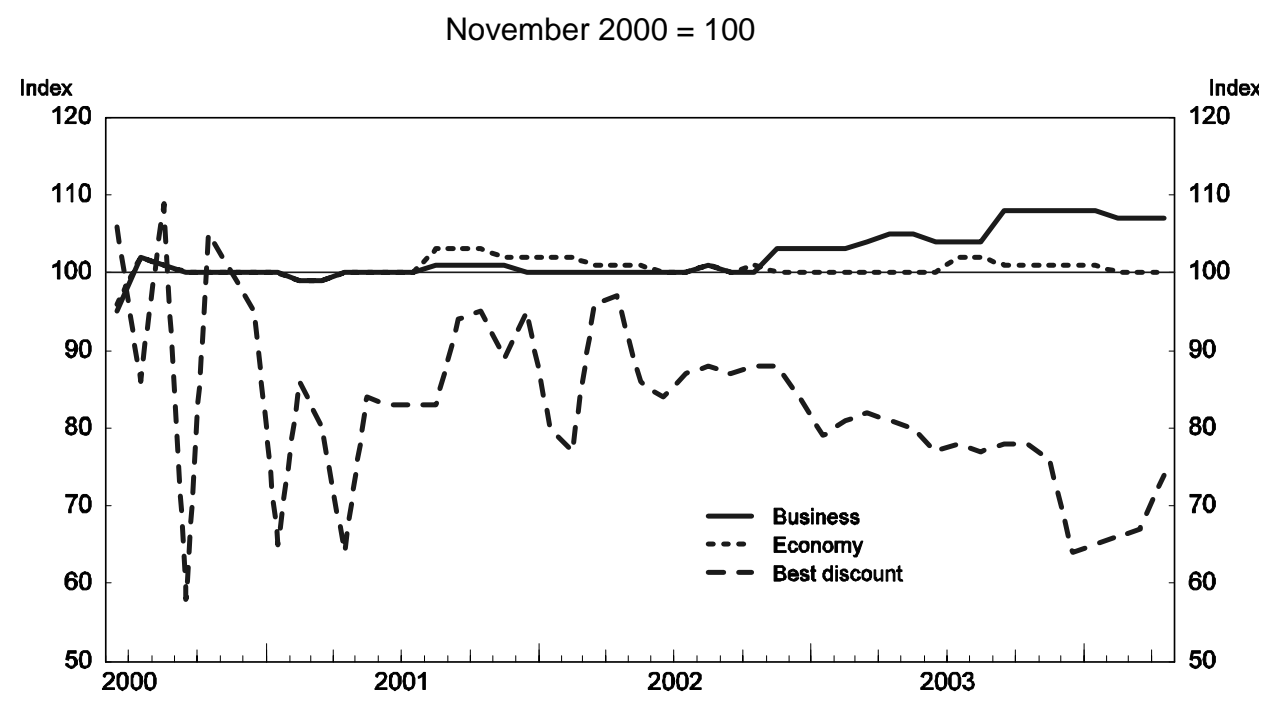

Source: Bureau of Transport and Regional Economies.

53. At the time the Government began privatising Federal airports, ${ }^{38}$ it established a comprehensive economic regulatory framework to apply to airport lessees. The arrangements were intended to promote operation of the airports in an efficient and commercial manner, while at the same time protecting airport users from any potential abuse of market power by airport operators. Arrangements included price monitoring and price caps on aeronautical charges. The Productivity Commission provided its report on the Price Regulation of Airport Services on 25 January 2002. The Commission recommended that there were insufficient grounds for an airport-specific access regime as the general access provisions available under Part IIIA of the TPA (and Part IV) provide sufficient safeguards for those seeking access to airport facilities. Instead, the Commission recommended five years of price monitoring (but no price caps) at Sydney, Melbourne, Brisbane, Perth, Adelaide, Canberra, and Darwin airports. The Government has accepted the Productivity Commission's recommendation. The price monitoring took effect 1 July 2002. Toward the end of the five-year period an independent review is to be carried out to ascertain the need for future airport price regulation. Figure 15 and 16 illustrate that airport charges have been relatively stable the last couple of years. The price level is higher than the late 1990s, though, which may be due to enhanced profit orientation in the wake of the 1997 liberalisation and the increased emphasis on security. 
Figure 15. Real international charges for a B747-400 landing and takeoff by airport

Total charge per return passenger

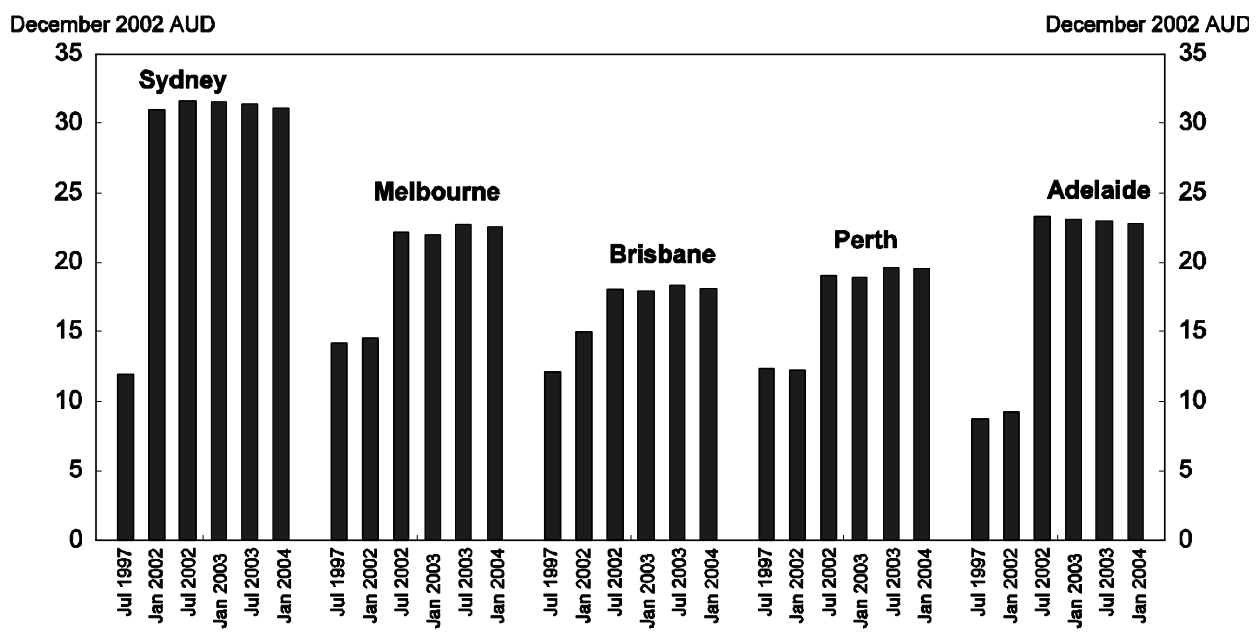

Source: Bureau of Transport and Regional Economies.

Figure 16. Real domestic charges for a B737-800 landing and takeoff by airport

Total charge per return passenger

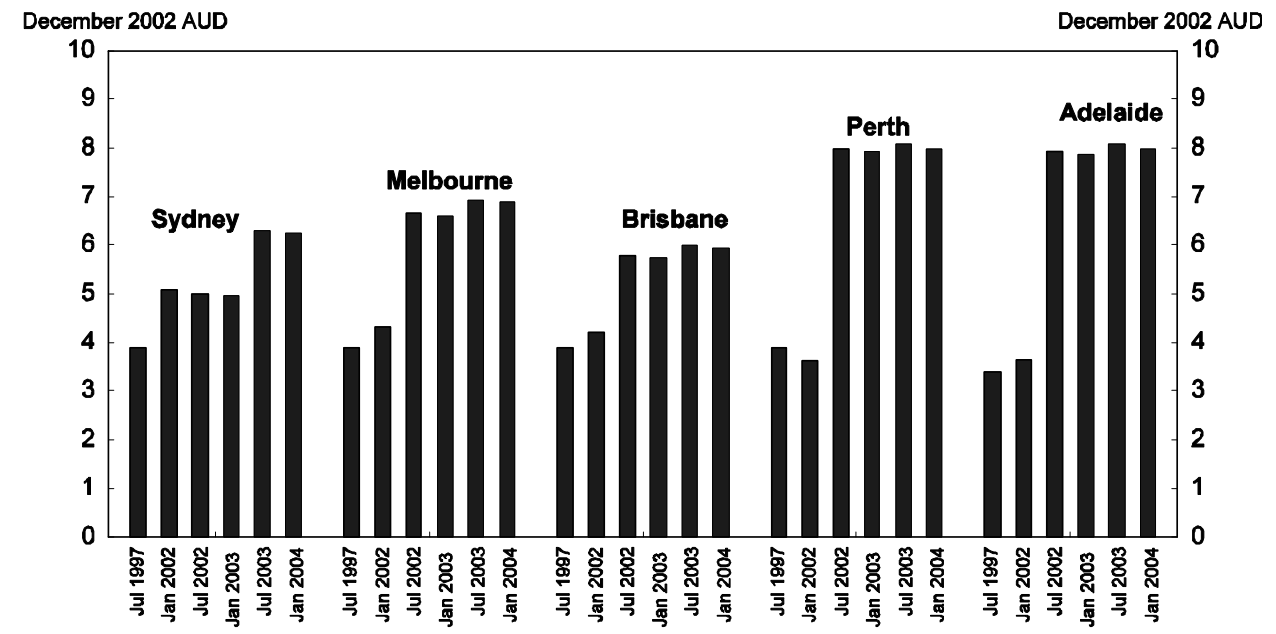

Source: Bureau of Transport and Regional Economies.

\section{Telecommunication}

54. The Australian Competition and Consumer Commission (ACCC) is responsible for the regulation of the telecommunications sector. The main player in this market is Telstra, of which approximately 51 per cent is owned by the Australian Government. Major legislative reforms have contributed to increased competition in the telecommunications industry and delivered benefits for consumers in terms of price and choice. ${ }^{39}$ In 1991, Telecom Australia (as Telstra was then known) lost its statutory monopoly position in the provision of telecommunications services. The Government adopted a duopoly policy for a fixed time frame and licensed Optus to be a second fixed network carrier, and Optus and Vodafone to be mobile telephone carriers in competition with Telstra. The Government allowed full competition in services in the 
Telecommunications Act 1997, and there are currently around 100 carriers (companies who own specified infrastructure facilities) and 1,000 service providers (NCC 2003b). The ACCC estimated Telstra's market share to be $43.5 \%$ in the mobile phone market in 2001-02 and Telstra's market share has been reported to be about 60 per cent in the corporate market. While there are many carriers and service providers, Telstra and Optus dominate the fixed and local access market, providing around 70 and $19 \%$ of the market respectively (PC 2001b).

55. In order to improve the efficiency of the regime regulating access to telecommunications network facilities, the Telecommunications Competition Act was passed in 2002. The Act seeks to prevent those owning and controlling networks from taking undue advantage of their powerful position. Measures include:

- $\quad$ speeding up access to core telecommunication services;

- facilitating investment in new telecommunications infrastructure (by facilitating investment certainty); and

- providing a more transparent market (by introducing an accounting separation framework for Telstra).

All of these measures are crucial in achieving a well-functioning telecommunications market, and as discussed below there are indications that the Australian market still has some way to go.

56. The key issue that encapsulates the three above measures is to establish a framework in which separate telecommunications companies along with Telstra could compete on common terms, making competitors less reliant on Telstra's infrastructure. The government, owning half of the incumbent, could prove reluctant to such a development, though, since it means decreasing rents. A necessary condition for a successful development in the telecommunications market is therefore to further privatise Telstra. There has also been some discussion about the structure of Telstra. NCC (2003b) suggested structural separation of the fixed network as an option, but this solution has been rejected by the government. Nevertheless, the unbundling ${ }^{40}$ of the local loop in 1998 was imperative to promoting competitiveness and thus lower prices.

57. The potential for improvement is apparent. Although the liberalisation since 1997 has had a positive impact on new entries (Figure 17), leading to significant decreases in call charges, prices in all segments of the market remain high when compared internationally (Figure 18). Further, the broadband market is developing slowly, reflecting the high internet access charges (Figure 19). All this suggests that access prices may be excessively high. Since March 2004 there have been dramatic price falls in the broadband market. As a result, broadband take-up increased to approximately 1.5 million (or 7.5 subscribers per 100 inhabitants) as of October 2004. However, it is yet unclear whether the price drop at the retail level has been fully reflected in access pricing. A way to tackle the problem would be to go ahead with the full privatization of Telstra and with unbundling the local loop to create a level playing field for competitors. What currently has been done, in the Competition Act of 2002, is that Telstra is required to provide separate accounts of its network and retail operations. Although accounting separation would help to increase transparency, it is a weak measure. There is a considerable scope for the network provider to load costs both of services and common costs onto the network. Acknowledging this problem, the Competition Act should be strengthened by demanding legal separation of network and retail, if the benefits of separation would exceed the costs. 
Figure 17. Estimates of market shares of new entrants
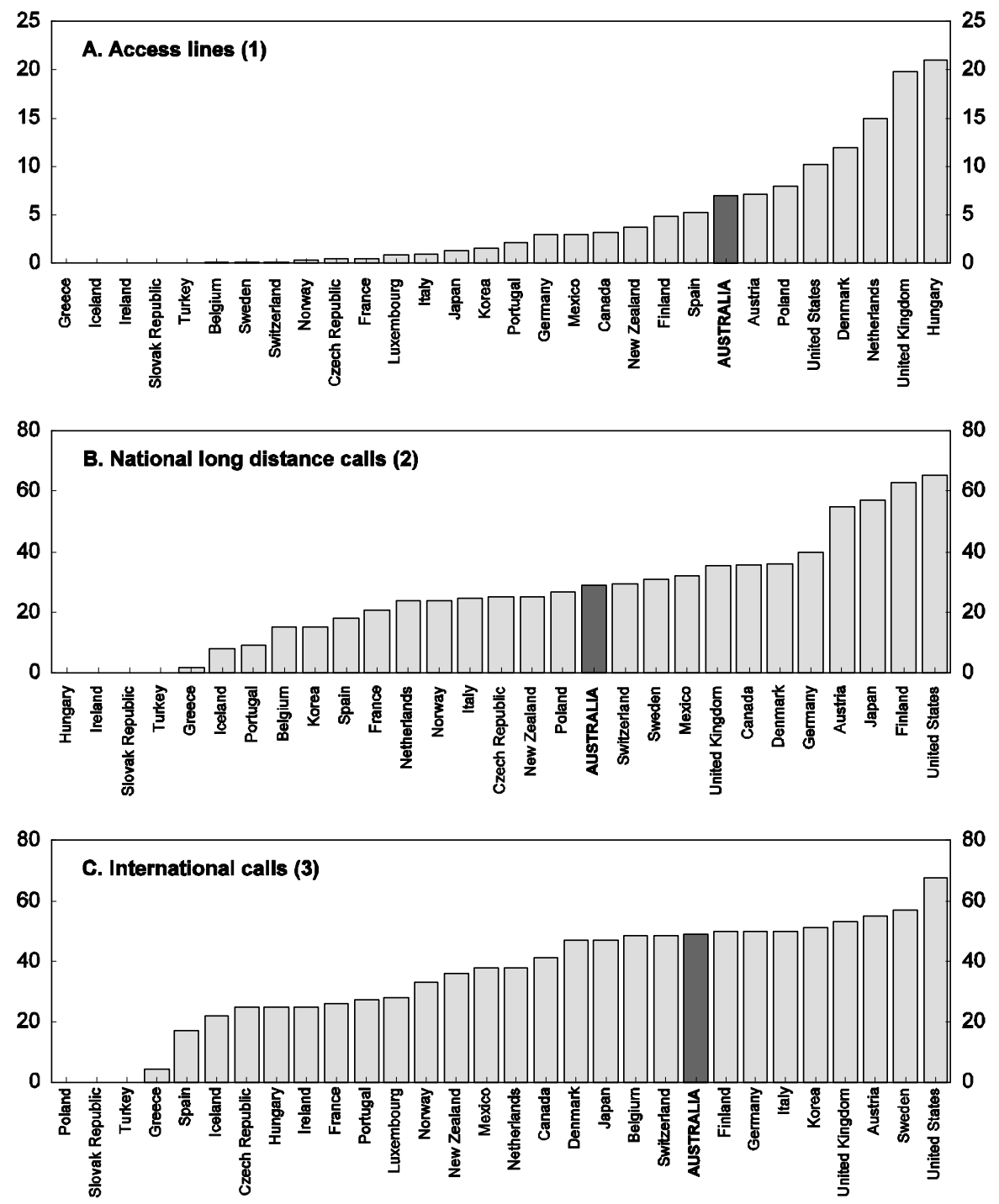

1. Percentage of access lines. For Japan and Switzerland data refers to 2000.

2. Percentage of switched minutes. For Ireland and New Zealand: 1998; for Japan, Switzerland and United States: 2000.

3. Percentage of minutes of international traffic. For Ireland, Japan, Switzerland and United States: 2000; for New Zealand: 1997.

Source: OECD, Communications Outlook database. 
Figure 18. Telecommunications charges US dollars, August 2004
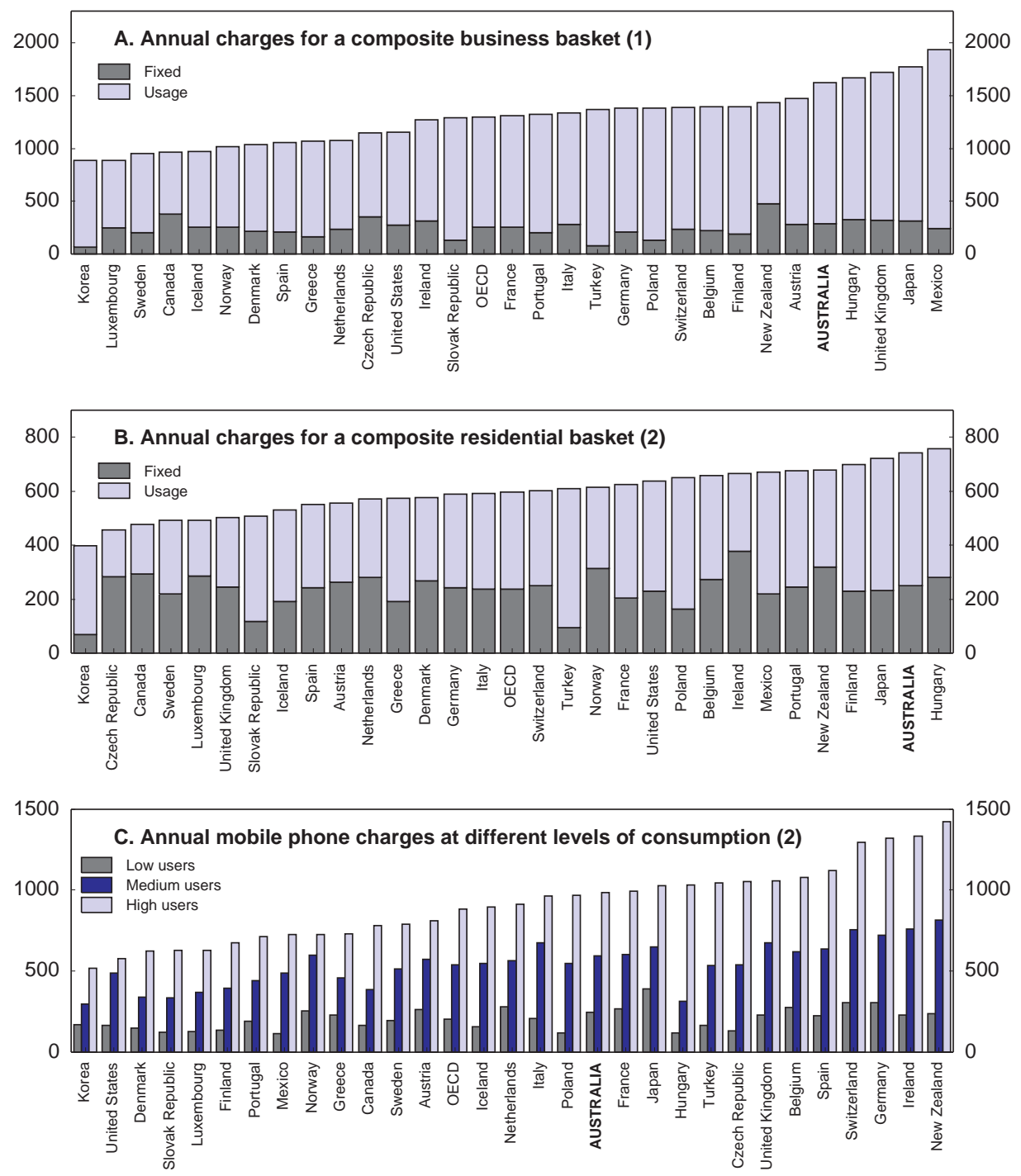

1. Excluding VAT.

2. Including VAT.

Source: OECD, Communications Outlook database. 
Figure 19. Broadband penetration and user charges
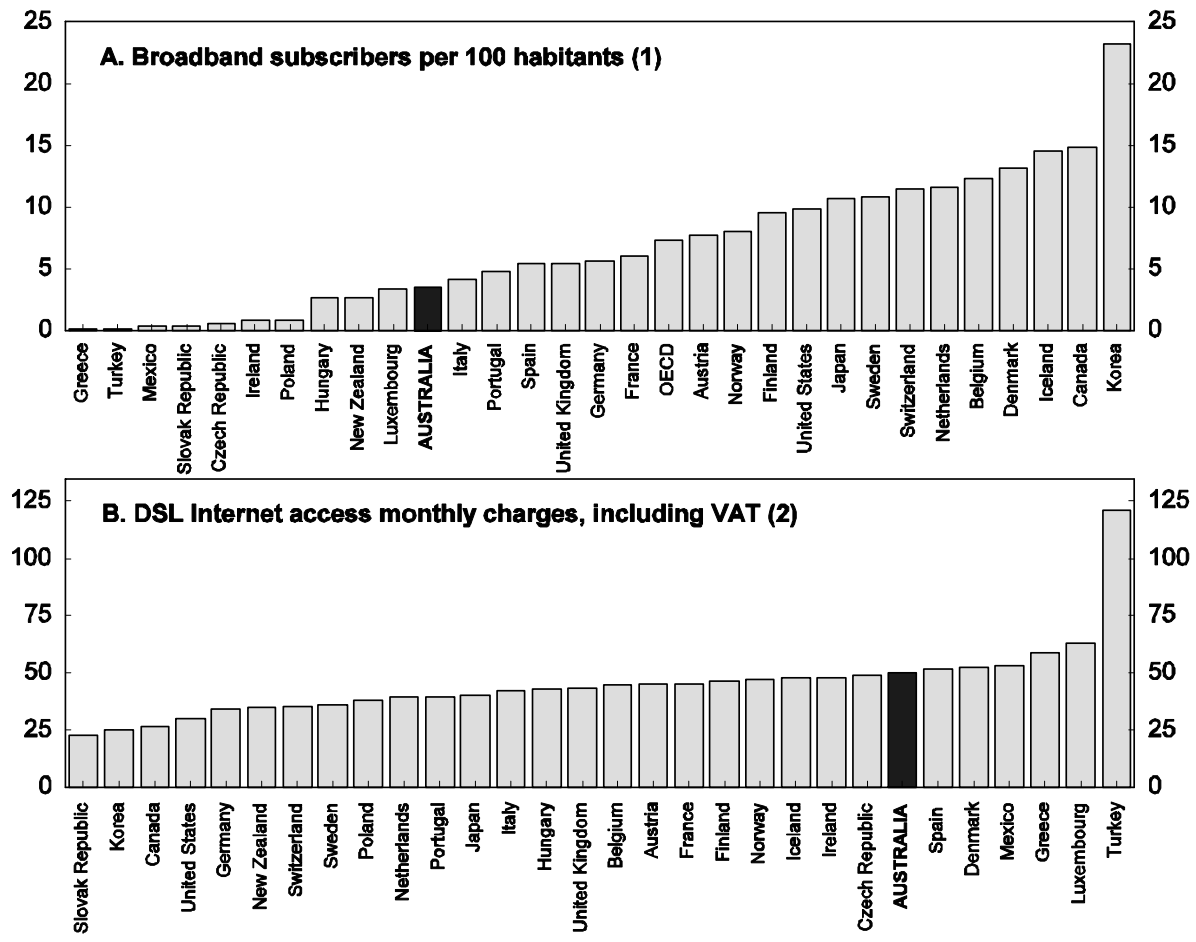

1. December 2003.

2. USD per month. Modem rentals are excluded, as in most countries they can be purchased by users. October 2003.

Source: OECD, Communications Outlook database.

\section{Television broadcasting}

58. The regulation of television broadcasting in Australia is the responsibility of the Commonwealth Government, and is not currently maximising competition. In its review of broadcasting, the Productivity Commission (2000b) described the regulatory arrangements as one that delays consumer adoption of digital technology and deprives businesses of opportunities to develop new products and services for the world as well as Australian markets. Entry into the free-to-air (FTA) sector is strictly controlled by government regulations that limit the number of commercial broadcasting licences. The three incumbents: channel Seven, Nine and Ten and their regional affiliates own most of the 53 commercial television licences in Australia. The increase in capacity resulting from digitisation of FTA broadcasting could provide increased opportunities for new services, greater choice and perhaps new entry into this market. However, government regulations prohibit many of these opportunities from emerging as they otherwise could (ACCC, 2003). By following this path, the government can still consider advice from the above mentioned Productivity Commission review; access to spectrum should be sold through a competitive bidding process and all broadcasting licence holders should pay fees based on their use of spectrum rather than on their revenue. The proposals would free up spectrum availability and make it possible for more broadcasters to enter the industry, and they should be adopted. The Government has also commenced a series of reviews into the digital regulatory framework, including into whether restrictions on the types of additional services FTA broadcasters can provide on their digital spectrum can be changed. There is also a review of arrangements applying to commercial television broadcasting after 31 December 2006, when the 
current moratorium on issuing new commercial television broadcasting licenses is to end. The review will examine the processes for taking decisions on the licensing of new entrants.

59. The Australian pay TV industry is highly concentrated, with three major players (Foxtel, Optus and Austar). Telstra owns 50 per cent of Foxtel, which again supplies 60 per cent of the metropolitan pay TV subscribers. The incumbent also owns two of the three major local access networks outside major cities. This dominant position is disquieting, as also pointed out by the commission and NCC (2003a). There is no effective competition in pay TV because the owner of the distribution networks, Telstra, also partly owns the major pay TV operator, Foxtel, making it virtually certain that other pay TV operators cannot face a level playing field. Further, following digitisation, Foxtel will be able to provide data services such as e-mail and internet access over its pay TV network. However, Telstra will have every incentive to restrict the development of such services by Foxtel where they would compete with services by Telstra. In so doing, a potential new source of competition in the future may therefore be diminished by Telstra's ownership of Foxtel. Consequently, Telstra should be required to divest the cable network and its shareholding in Foxtel, provided independent assessment shows the benefits of divestiture would exceed the costs.

\section{Postal industry}

60. Draft legislation which sought to reduce Australia Post's reserved service and to open the postal market to increased competition through the introduction of a postal access regime, was withdrawn from the Parliament in early 2001 as it did not attract sufficient support. Another effort should be undertaken to enhance competition in the postal services market.

\section{Other regulatory reform areas}

\section{Retail distribution}

61. Australia's retail sector has undergone a marked restructuring over the past 20 years or so, transforming a sector of small independent shops to one where large retailers capture significant shares of their relevant markets. The trend towards concentration is particularly evident in the grocery sector, ${ }^{41}$ with the two vertically integrated supermarket chains accounting for approximately $77 \%$ of grocery and perishables sold nationally - a high market concentration by international standards (Figure 20). The high 


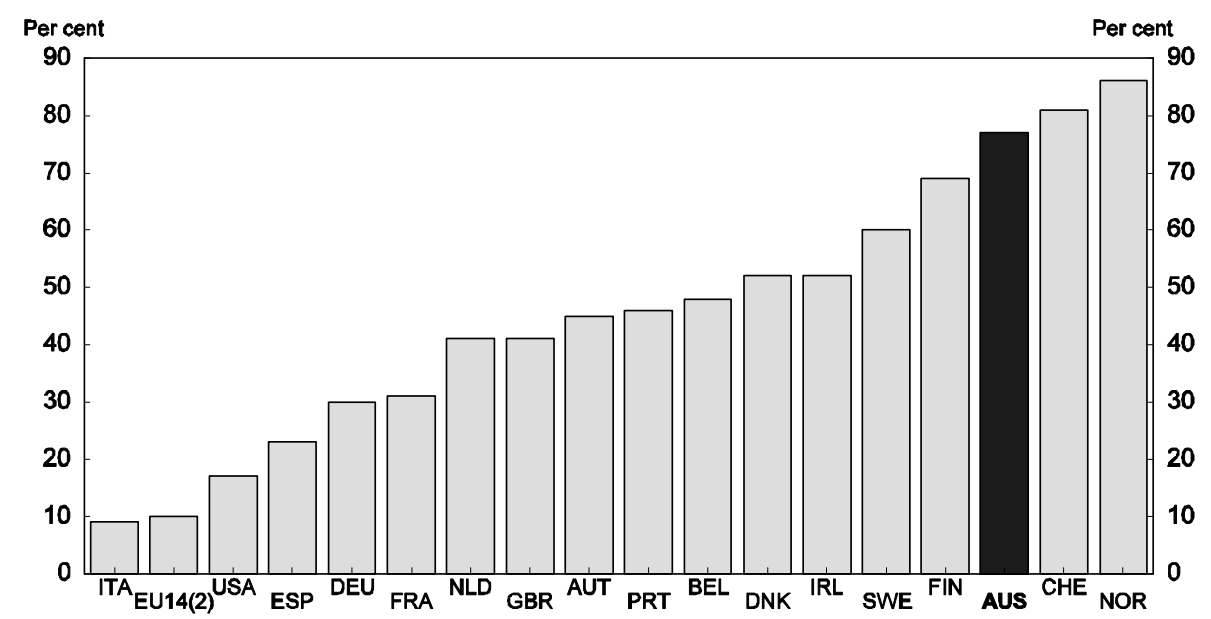

1. Market shares of the first three firms based on sales, 1996 data.

2. EU15 excluding Greece.

Source: O. Boylaud and G. Nicoletti (2001), "Regulatory Reform in Retail Distribution"', OECD Economic Studies No 32, $2001 / 1$.

and increasing concentration is driven largely by the growing importance of economies of scale and scope. Significant developments in the industry include the expansion by the major market participants into liquor and pharmaceutical retailing, and the convergence of petrol and grocery retailing, particularly through "shopper dockets", binding petrol discounts to grocery purchases.

62. These changes have occurred against a background of an easing of regulation. OECD evidence suggests that less stringent regulations on opening hours and large-scale stores have positive effects on efficiency and performance, while over-regulation is likely to result in higher prices and inhibit modernisation (Boylaud and Nicoletti, 2001). In international comparison Australia had in 1998 one of the least restrictive regulations in retail distribution in the OECD area (Figure 21), which might have contributed to good productivity performance of the sector. However, this does not mean that there is no scope for further regulatory easing. Despite significant changes in state-level legislation on shop opening hours, remaining restrictions continue to hamper competition by discriminating between categories of sellers on the basis of location, size or product sold. ${ }^{42}$ Some jurisdictions restrict the trading hours of large retailers, in order to permit small retailers to trade at certain hours without competition of larger retailers. The evidence, however, reveals that such restrictions do not serve the public interest (National Competition Council, 2003a). Two more specific competition issues in the retailing sector emerge from the liquor licensing laws and the legislation governing petrol retailing both imposing barriers to entry by potential sellers (See Annex A2). 
Figure 21. Summary indicators of regulation in retail trade $1998^{1}$

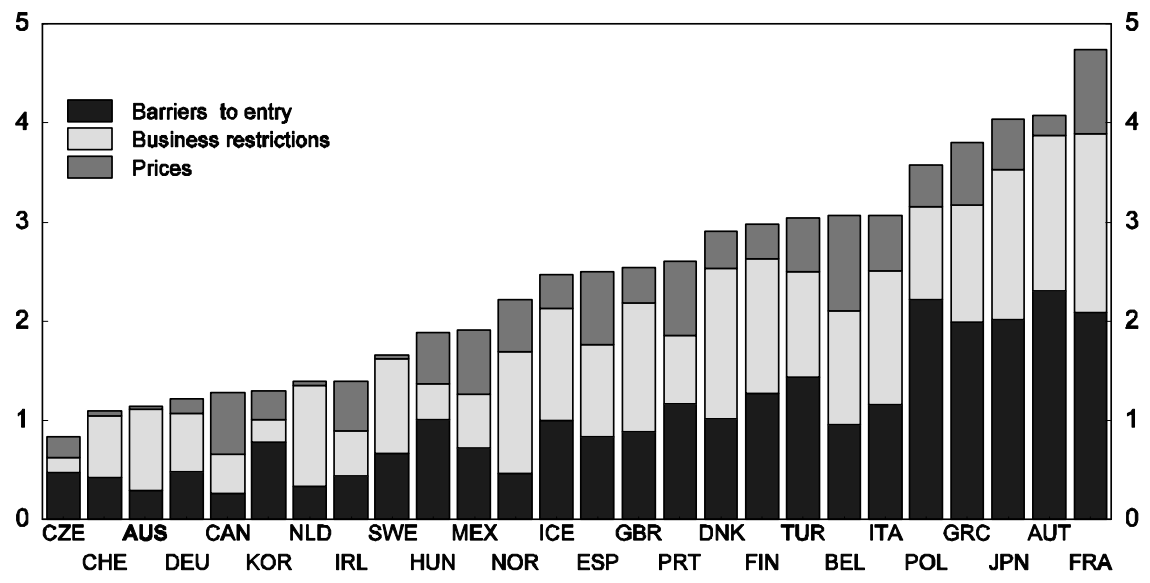

1. The scale of indicators is $0-6$ from least to most restrictive.

Source: Boylaud (2000), "Regulatory Reform in Road Freight and Retail Distribution", OECD Economics Department Working Papers, No. 255.

63. In general, the current structure of the retail sector appears to be beneficial for consumers. According to the 1999 Report by the Joint Select Committee on the Retailing Sector ("the Baird Committee") and a 2004 Report by the Australian Competition Consumer Commission (ACCC), competition in the sector is deemed healthy. This is despite the expansion of major supermarket chains, with the retailers competing briskly among themselves on price and choice. Improved consumer welfare is evidenced by a fall in real prices of many grocery items since the mid-1980s, a significant expansion in product range and services (one-stop shopping), and extended trading hours.

64. While the restructuring of grocery retailing tends to improve consumer welfare overall, concern has been raised about the impact of the expansion of the major chains on the ability of small and independent retailers to compete on equal terms in the sector. Although the Baird Committee concluded that the market was competitive, it also concluded that the sector was "heavily concentrated and oligopolistic in nature", with vertical integration enhancing further the market power of the major chains and giving them commercial advantages over the independents. However, the Committee did not find a compelling case for the imposition of a market cap on the share of each major chain - as proposed by the National Association of Retail Grocers of Australia - or for divestiture of stores in the current market structure (although it pointed to the potential merit of divestiture as a safeguard to competition in cases of high concentration). ${ }^{43}$ The Dawson Committee in 2003 also considered and rejected such interventions. Concerns have also been expressed about the marketing practices facilitating the convergence of petrol and grocery retailing, and in particular, about the effects of shopper docket discount schemes, offered by major chains, on the number of independents operating in the retail petroleum industry (see Annex A2). These issues were considered by the ACCC in 2004. The ACCC concluded that shopper docket arrangements had encouraged competition and lower prices for consumers. Further, the ACCC found that the arrangements between grocery and petrol retailers would be unlikely to result in a substantial lessening of competition.

65. In addition to allowing shopper docket schemes to continue, the Australian Competition and Consumer Commission (ACCC) has also decided not to oppose the acquisition by a major domestic chain (Coles Myer Ltd) of a number of independent supermarket outlets, ${ }^{44}$ as this was not deemed likely to lead to a reduction in competition that would breach the relevant provision in the Trade Practices Act (section 
50). ${ }^{45}$ ACCC found on previous occasions that the major grocery chains in Australia have, in general, acquired independent supermarkets in areas where they were not represented, thereby unlikely to raise competition concerns at the local retail level. However, the ACCC recognised the challenges posed by "creeping acquisitions", noting that it would continue to scrutinize any further moves by major grocery chains to purchase smaller independent operators. Creeping acquisitions allow major chains to build their market share by attrition, through the purchase of smaller independent operators over time. As such, it has been put to the ACCC that this type of acquisition may effectively circumvent the relevant Trade Practices Act clause, as it would be unlikely for an individual purchase to lead to a substantial increase in concentration. While the current market structure is judged to be in general competitive, raising no important concerns over the short run, the issue of "creeping acquisitions" will continue to require attention in order to prevent an unacceptably high degree of concentration and upward pressure on retail prices in the longer run. In addition, increased market concentration changes the balance of power between retailers and suppliers, creating oligopsony in the upstream market, with negative effects on competition (ACCC, 2004). By reducing sellers' profitability, increased buyer power may discourage entry of new producers. That said, the ACCC concluded that the grocery industry is 'dynamic, innovative and competitive' (ACCC 2004). This has been underlined by the recent entry and expansion of some new players. The issue of creeping acquisitions was also considered by the Dawson Committee in 2003. The Committee found that the statutory test of "substantial lessening of competition" could deal with this problem.

66. Summing up, the retail sector in Australia appears to operate in a competitive environment at present, with a considerable amount of rivalry between the major chains in grocery retailing. Reductions in prices of many grocery items since the mid-1980s, and significant expansion in product range provide support to this view. However, market power on the part of large retailers needs to be closely monitored and assessed by the competition authority. Claims about predatory pricing were examined by the Baird Committee. Below-cost pricing is not prohibited by the Trade Practices Act, except where there is a misuse of market power (section 46). The Committee recommended the granting of wider powers to ACCC to bring representative actions and to seek damages on behalf of third parties. This recommendation has been accepted and the relevant amendments were made in 2001. Moreover, a package of reforms to the Trade Practices Act, announced by the Treasurer in June 2004, includes an amendment to the current clause regarding the misuse of market power to provide some additional guidance to courts in the consideration of predatory pricing cases. The issue of creeping acquisitions should continue to be carefully scrutinised. Although the dominant retail chains compete strongly with each other at present, the temptation to collude to protect margins might arise in a future economic downturn. If the dominant retailers were to fall to such a temptation, the full force of the TPA can be applied and enforced by the ACCC.

\section{Professional services}

67. Professional services in Australia are subject to a broad range of regulations, comprising both statutory provisions and a significant element of self-regulation. ${ }^{46}$ Examples of professional regulation include: entry and registration requirements, restrictions on the use of the title and on the practice of profession, disciplinary processes, restrictions in advertising under the rules for business conduct, and business licensing requirements. Regulation of professional services is widespread in OECD countries and is usually justified as a way to protect consumers by alleviating information asymmetries and ensuring quality. There is little empirical evidence, however, to suggest that regulatory interventions in the area of professional services that prevent competition improve consumer welfare. In practice, these restrictions have been associated with higher prices and weaker innovative activity without significant quality improvements, serving mainly the interest of the profession. ${ }^{47}$ 


\section{ECO/WKP(2005)38}

\section{Restrictions on competition}

68. A wide variety of laws, regulations, professional rules and responsibilities govern entry and practice within the health and legal professions. Key regulatory restrictions on competition include reserved areas of practice and rules on business conduct, especially in relation to the ownership, advertising, and professional indemnity insurance ${ }^{48}$ (See Annex A2). An additional issue arise from the registration of certain health professions in some but not all jurisdictions, raising questions about the public benefit from continued registration.

69. An emerging trend of the legislation review of health professions is towards the introduction of mandatory professional indemnity insurance requirements. Such type of insurance - designed to cover the costs for professionals of any judgment of liability due to professional malpractice - is obligatory for registered legal practitioners in all jurisdictions. The National Competition Council (NCC) considers that compulsory indemnity insurance requirements are consistent with the National Competition Policy principles. However, the means of provision of this type of insurance may have significant competition implications. ${ }^{49}$ Reform involving professional insurance could be facilitated (or made effective) if insurance provision itself were more competitive. ${ }^{50}$

70. Regarding architects, the Productivity Commission (2000a) assessed that the costs of current regulation outweigh benefits, suggesting a repeal of the various Architects Acts (after a two-year notification period) in all jurisdictions. The Commission noted that consumer protection and spillover related to the building industry could be obtained more effectively through self-regulation and other existing legislation. A national working party (with a representative of each state) was set up to develop a response to the review. The group recommended, instead, a reform of existing legislation by removing those elements considered as restricting competition (such as practice reservation). Accordingly, each government committed to the implementation of the reform set up by the national working group.

\section{The reform process}

71. The implementation speed of reform varies across professions, being particularly slow in pharmaceuticals and more satisfactory in other areas, such as that of building occupations. ${ }^{51}$ Regarding pharmaceutical services, the Council of Australian Governments commissioned in 1999 a national review of pharmacy legislation - the Wilkinson review. Following it, jurisdictions agreed to implement a range of reforms. These include removing caps on the number of pharmacies a pharmacist can own, and permitting non-pharmacists to have a pecuniary interest in pharmacies other than based on ownership (for example, profit sharing or joint venture arrangement). It was also agreed to temporarily retain legislated ownership restrictions, preventing non-pharmacists from owing pharmacies, with limited exceptions (regarding pharmacies owned by friendly societies, ${ }^{52}$ and those owned by non-pharmacists before the current ownership restrictions came to force). Ownership restrictions cover pharmacies in all states (apart from the Northern Territory). The main reason for postponing their reform was that it could have a disruptive impact on the pharmacy industry in the short term, in light of the perceived transitional/structural costs involved in the other reforms recommended by the review. Changes agreed by the Australian Government with individual states and territories have gone some way to relaxing the restrictions on the ownership of pharmacies and to move toward, but not fully meet, the reforms recommended in the Wilkinson review process.

72. Summing up, although the pace of reforms varies across professions, implementation could be faster. There is still scope for relaxing some existing regulation governing professions or reforming them, so as to minimise their distorting effects on competition. Replacing, for example, remaining ownership rules in the areas of dentistry ${ }^{53}$ by less stringent schemes, allowing non-health professionals to own health 
care practices but call for disciplinary action in cases of inappropriate commercial influence on decision making, would ensure accountability for professional conduct, while having less impact on competition (see Annex A2). As a positive step, many jurisdictions are conducting reviews of most, or all, health practitioner legislation aiming to make entry requirements more flexible (including a replacement in some states of broad practice restrictions by specific core practice restrictions), while providing, in general, for uniform regulation for most health professions in such areas as advertising and disciplinary processes. However, reforms are proceeding at a slow pace. Moreover, the assignment of power to the relevant health profession boards to create specific requirements for particular professions requires close monitoring, as it may facilitate the pursuit of their own interests to the detriment of those of their affiliates. Delays are also observed with regards to the implementation of the agreed state-level reforms in pharmaceutical services, where continuing ownership restrictions have the potential of disadvantaging the community, for example, through reduced access to services and increased costs of pharmaceuticals. These reforms should be further combined with a timely removal of restrictions on the number and location of Pharmaceutical Benefits Scheme (PBS) - licensed pharmacies, forming significant barriers to competition in the industry.

73. Reducing market segmentation arising from differences in professional regulations across the states would also be welfare-enhancing. This is particularly true in the case of legal professions, where state-differentiation of regulations governing the profession creates significant obstacles to legal firms wishing to work across state borders, while necessitating the maintenance of expensive and complex business structures in order to comply with the different regulations, with the additional cost often being passed on to clients (NCC, 2000a). The development of consistent regulations under the National Model Laws project is a step in the right direction, expected - as highlighted by the NCC - to lower hindrances to competition across jurisdictions, and significantly increase competition in the industry at a national level. However, the reform programmes are lagging behind schedule.

\section{Trade policy}

\section{Steps to trade liberalisation}

74. Although a strong momentum for liberalisation opened markets all over the world for much of the post-war period, Australia's level of average tariffs has only quite recently come down to that of other OECD-countries. However, Australia has been an active international negotiator since the 1990s, pressing multilateral trade liberalisation forward in the GATT/WTO rounds and even implementing a series of unilateral tariff cuts to facilitate increased competition on its domestic market. Although Australia typically has favoured multilateral or unilateral trade liberalisation, it has also negotiated some bilateral agreements, e.g. with New Zealand (1983), Singapore (2002), and Thailand (2003). Most recently, it has negotiated a Free Trade Agreement (FTA) with the United States. Annex A4 provides a brief description of the major milestones in Australia's trade liberalisation process.

75. Bilateral and regional trade agreements can usefully complement the multilateral trading system by allowing a smaller group of countries to go further in some sectors than would have been possible in a multilateral setting and to serve as laboratories for future consideration in multilateral negotiations. Nevertheless, bilateral and regional trade agreements can have a trade distorting as well as a trade creating component. There is furthermore a danger that the coherence and predictability offered by multilateralism will be weakened if governments increasingly turn to regional agreements to manage their trade interests. A maze of conflicting regional regulations, standards and rules of origin risk becoming the new "walls" between blocks.

76. Against this background, the recently negotiated FTAs with Singapore, Thailand and the US merit close scrutiny, as they run counter to Australia's general unilateral/multilateral approach. Although it is too early at present to give a plausible estimate of the net economic impacts of such agreements, two 
general concerns should be raised. Firstly, the increased complexity such agreements inherently impose on traders could very well contribute to hamper overall trade. Secondly, a decline in economic efficiency can be expected because of import distortion effects. True, trade diversion effects can be dampened, at least for the least developed countries, through the General System of Preferences. In fact, in the case of Australia, since 1 July 2003, it has provided tariff and quota-free entry for all goods originating in Least Developed Countries, subject to a broad local content rule.

\section{Scope for further improvement}

77. Although Australia should be commended for its recent multilateral and unilateral trade liberalisation efforts, there is, as in most other countries, unfinished business in the pursuit of freer trade. ${ }^{54}$ After reducing protection over the past 15 years, textiles, clothing and footwear (TCF) producers have been increasingly exposed to competition. In 2001, the industry managed to reach an agreement with the government to freeze tariffs at the 2000 level until 2005, when TCF tariffs will be reduced, and to receive A $\$ 678$ million in transitional budgetary support in the same period. ${ }^{55}$ In 2003, the Government announced a continuation of the tariff reform process which will see most TCF tariffs reduced to $5 \%$ in 2010, the general tariff rate. ${ }^{56}$ To assist industry adjust to the lower tariff environment the Government also announced a further $\$ 747$ million in transitional budgetary support over 10 years. The tariff reforms and the assistance package by the Government are generally in line with that recommended by the Productivity Commission (2003c), which achieves reform in a measured manner and continues to provide industry with an element of predictability.

78. The automobile industry is also subject to special assistance. Generally, the key elements of the current assistance arrangements, including a freeze of the 15 per cent tariff rate, are due to terminate in 2005. Under arrangements announced by the Government in December 2002, tariffs for passenger motor vehicles and automotive components will be reduced to $10 \%$ from 1 January 2005 and to 5\% from 1 January 2010. The government has also allocated $\$ 4.2$ billion in assistance to the industry over 10 years through the post-2005 Automotive Competitiveness and Investment Scheme (ACIS). The ACIS, which will operate from 1 January 2006 to 31 December 2015, aims to encourage competitive investments by firms in the automotive industry in order to achieve sustainable growth.

79. Lastly, Australia has strict quarantine, sanitary and phytosanitary regulations. This reflects its island geography, which has isolated it from many diseases and pests in its flora and fauna. Many countries find that access to the Australian market on agri-food products is particularly difficult. Especially, they complain about the lengthy risk assessment procedures, which may take years to complete before eventually changing the import rules. Currently the dispute settlement body of the WTO is handling a complaint regarding the Australian quarantine regime, but a conclusion to this complex issue is not expected anytime soon. Recent initiatives to allow the testing and certifying of products in exporting countries, using recognised procedures and institutes is a positive step.

\section{Overall assessment and scope for further action}

80. In sum, enhancing product market competition has been central to microeconomic reform in Australia and has been a crucial element in improving general economic performance. Following the trade liberalisation of the 1970s and 1980s, competition in product markets has intensified since 1995, as a result of the National Competition Policy (NCP), the most extensive economic reform programme in Australia's history. NCP has set out competition principles which extended the reach of competition law to previously exempt activities, including Government Business Enterprises and a broad range of professional and occupational services. It has provided a coherent framework for reforms already underway in major infrastructure industries as well as providing impetus to complete these reforms. Using competition payments to leverage reform outcomes in areas of State and Territory responsibility and charging an 
independent body - the National Competition Council (NCC) - with assessing reform progress has proven highly effective. There is no doubt that reform would have been far slower and less comprehensive without competition payments. Although these payments (now at around A $\$ 800$ million per annum) are not very large relative to jurisdictions' budgets, they nevertheless represent a significant source of incremental funds. Moreover, tying performance to financial rewards has enabled governments to resist pressure from lobby groups by claiming that they have no choice other than to meet their NCP commitments. ${ }^{57}$ The NCP arrangements are currently under review. The Productivity Commission is conducting an inquiry into the future of NCP and has released a discussion draft report (with a final report due by the end of February 2005). This will inform discussions about the future of competition policy and a future reform agenda in the COAG review of NCP to be conducted in 2005.

81. Among major achievements of the competition policy reform are the establishment of an overarching national access regime - together with sector-specific regimes - which introduced third-party access arrangements for infrastructure services such as gas pipelines and rail track networks. Independent authorities were also established in all jurisdictions to monitor and set prices for monopoly services. Some 1800 individual pieces of legislation have been assessed and many of those which were found not to provide a net public benefit have been reformed. The framework for a more competitive electricity market has been established, trade in gas has been liberalised, and progress has been made toward developing a viable and sustainable water industry. The NCP road transport commitments are almost completed. The telecommunications market was fully liberalised in 1997 and regulation separated from the commercial activities of the incumbent telecommunications operator Telstra. In addition, the increasingly effective application of Australia's competition law, the Trade Practices Act (TPA), reduced the power of firms over prices and forced them to control costs better. A leniency programme was introduced in 2003, whose promise of reduced civil fines in cartel cases has yielded some enforcement successes. Among the recently debated proposals to reform the TPA are increased sanctions to strengthen deterrence against horizontal price fixing. Altogether, the implementation of Australia's ambitious and comprehensive competition policy reforms over past nine years or so has undoubtedly made a substantial contribution to the recent improvement in labour and multifactor productivity and in economic growth.

82. Unfinished business encompasses the completion of the legislation review, which has fallen well short of initial expectations, which was for a closure of this element of the NCP by mid-2002. Areas where reforms are yet to be completed include agricultural marketing arrangements, liquor licensing, compulsory insurance schemes, pharmacies, the professions and occupations (health and legal practitioners and some building related trades), and the regulation of taxis. Bringing the reform programme to completion according to an announced timetable is important to avoid the impression that difficult reforms can be deferred ad infinitum, which would jeopardise future reform programmes. Among jurisdictions, the federal government in particular should make stronger efforts to raise its own compliance rate, which has been among the lowest of all Australian governments and is not consistent with its ambition to raise overall competitive pressures. This would also strengthen the federal government's position in its endeavours to convince those opposing reform of the overall beneficial effects of enhanced product market competition.

83. Looking to the future, discipline on all government could be enhanced further by making all legislation reviews public, which was not required hitherto. In some instances, this has allowed jurisdictions not to release reviews where outcomes had been controversial. More effort should also be put on specifying required policies more clearly, to avoid governments to approach reform processes in a minimalist way.

84. Regarding infrastructure services, a fully competitive national electricity market has yet to be realised even across the contiguous eastern states, including full retail contestability. As an important prerequisite, regulatory inconsistency needs to be removed, which arises from the co-existence of state and national regulators in both the electricity and gas sectors, as planned. Moreover, grid interconnection 
should be improved and competition in electricity generation intensified by setting better incentives for investment in transmission and generation. ${ }^{59}$ And while urban water reforms are largely complete, the pace of rural water reform is slow. Main issues which need to be addressed are the specification, enforcement and trading of water property rights as well as the determination and pricing of appropriate environmental allocations. Accordingly, the Council of Australian Governments' National Water Initiative of 2004 aims to improve the security of water access entitlements, ensure ecosystems health and encourage expansion of water markets and trading. ${ }^{60}$ Cross-subsidisation of water usage as between urban and rural users, and also between different types of agricultural users, should be phased out over time.

85. The NCP road transport reform commitments, which cover a narrower range of reform modules than initially proposed by the National Road Transport Commission, are now almost complete. Like rail reform, other road reform is being pursued outside the NCP framework through a co-operative intergovernmental process. Recently announced national land transport reforms planned under the AusLink framework need to be effectively implemented, to ensure efficient long-term investment and better integration of the network. Efforts should be made to promote competition in ocean shipping. More broadly, Australian governments should seek to establish an integrated reform agenda within a co-operative assessable framework covering all elements of land transport and shipping transport. Competition in fixed-line telecommunications should be promoted by strategies designed to facilitate further access by competitors and Telstra should be required to divest its cable network and its shareholding in a major pay-TV supplier, provided independent assessment shows the benefits of divestiture would exceed the costs. Another effort should be undertaken to open the postal services market to competition. ${ }^{61}$

86. In the context of network industries which operate over several geographical jurisdictions there is the issue of ensuring efficient infrastructure investment, a problem which is not resolved by established national access regimes themselves. Efficient infrastructure investment is a complex problem in any economy, as market signals often do not provide sufficient guidance, market power creates gaps between private and social rates of return, and investment decisions have significant redistributive impacts across regions. There is no obvious "best practice" solution to this problem, and the Australian approach will have to take into account the specific constitutional allocation of competences. But in general, economic efficiency is most likely to be achieved if the analysis is undertaken at a national level, and decisions coordinated across levels of government. 
87. As noted, the future of NCP will be the subject of a review by COAG in 2005. The review will need to consider the appropriate framework for a reinvigorated, nationally coordinated reform programme including the role of financial rewards and assessment processes. It will also need to consider reform priorities and expanding the scope of reform efforts to new areas. Health, education, childcare and community services are areas which offer a great potential for closer coordination of reforms across Australian governments to enhance efficiency, given Australia's brand of fiscal federalism with constitutional powers and responsibilities residing with sub-central governments. This is all the more so as the ageing of the population will impact on government services, revenues and retirement income policies. Environmental degradation represents another risk to future growth. An integrated sustainability package could extend to matters such as land use planning (and clearing), and pollution (including greenhouse gas abatement), ${ }^{62}$ using market-related instrument approaches to environmental management; only the NCP water reform programme addresses such matters at present. This has inter-jurisdictional implications as the Constitution has left most environmental responsibilities to the states, but their interests differ depending on energy production patterns, biodiversity concerns and water-use. Hence, a co-ordinated regional and national approach is needed to deal with cross-state spillovers and the need to implement commitments made under international agreements, as well as to ensure that there is a sufficient range of instruments available to cope with environmental problems. There may also be scope to apply an NCP-type framework to improve the efficiency of the labour market, with the industrial relations system having an important inter-jurisdictional dimension. In particular, the Australian dual system of federal and State industrial relations system results in significant inefficiencies for many enterprises which have some employees covered by the federal system and some by the relevant state system.

\section{Box 3. Recommendations regarding product market competition}

\section{Competition law and policy}

A formal process for reviewing proposed mergers should be established to make the Australian Competition and Consumer Commission more accountable.

The maximum level of civil fines for cartel violations should be raised, to bring Australia into line with other major jurisdictions.

New legislation should be introduced to reduce the uncertainty in the current law on the control of abuses of dominant positions of firms and to avoid overly legalistic analyses of the significance of market power.

\section{Legislation review}

The reforms in the areas identified by the legislation review should be completed. They include agricultural marketing arrangements, liquor licensing, compulsory insurance schemes, pharmacies, the professions and occupations (health and legal practitioners and some building related trades).

The federal government in particular should make stronger efforts to raise its own compliance with the imperatives of National Competition Policy (NCP), which would strengthen the government's position in its endeavours to convince opposing parties of the overall beneficial effects of enhanced product market competition.

\section{Network industries}

\section{General}

The federal Government should explore ways of ensuring cost-effective and timely investment decisions in regulated network sectors that operate across several jurisdictions. 


\section{Electricity and gas}

Stronger efforts should be devoted to the implementation of a fully competitive national electricity market, including full retail contestability. In particular:

- $\quad$ grid interconnection should be improved and competition in electricity generation intensified by setting better incentives for investment in transmission and generation; and

- $\quad$ regulatory inconsistency, arising from the co-existence of state and national regulators in both the electricity and gas sectors, needs to be removed as planned.

\section{Transport}

Recently announced national land transport reforms planned under the AusLink framework need to be effectively implemented, to ensure efficient long-term investment and better integration of the network. Efforts should also be made to promote competition in ocean shipping with a current review by the Productivity Commission suggesting that repeal of the industry-specific regime for international liner cargo shipping will improve outcomes. More broadly, Australian governments should seek to establish an integrated reform agenda within a co-operative framework covering all elements of land transport and shipping transport.

\section{Telecommunications}

Competition in fixed-line telecommunications should be promoted by strategies designed to facilitate further access by competitors.

Telstra, the dominant telecom operator, should be required to divest its cable network and its shareholding in a major pay-TV supplier, provided independent assessment shows the benefits of divestiture would exceed the costs.

\section{Postal services}

Another effort should be undertaken to open the postal services market to competition.

\section{Water provision}

Rural water reform needs to be accelerated through better specification, enforcement and trading of water property rights as well as the determination and pricing of appropriate environmental allocations.

The security of water access entitlements should be improved, the ecosystems health is ensured and the expansion of water markets and trading be encouraged.

Cross-subsidisation of water usage as between urban and rural users, and also between different types of agricultural users, should be phased out over time.

\section{The future reform agenda}

The Productivity Commission is currently undertaking an inquiry into the future of NCP in the lead up to a review of NCP by the Council of Australian Governments (COAG) in 2005. This opportunity should be taken to address the unfinished business of the current NCP agenda, reinvigorate the commitment to reform, and extend competition and efficiency enhancing reforms to appropriate new areas, including social policy. 
ECO/WKP(2005)38

\section{NOTES}

1 The first three authors are economists in the Economics Department and Michael Wise works in the Competition Division of the OECD. This paper draws on material originally produced for the OECD Economic Survey of Australia published in January 2005 under the responsibility of the Economic and Development Review Committee. The authors are indebted to Nicholas Vanston for comments and drafting suggestions. Helpful comments were also provided by Mike Feiner, Val Koromzay and Andrew Dean. Special thanks go to Sylvie Foucher-Hantala for excellent technical assistance.

2. The findings of the OECD Growth Project are summarised in OECD (2003).

3. See Productivity Commission (1999a).

4. See OECD (1992).

5. Australia's economic decline relative to other countries nurtured fears at the time that it risked becoming a "banana republic" and that, in particular in view of the performance of some Asian countries, "within two generations, unskilled Australian workers could be looking for jobs as maids and waiters in Kuala Lumpur" (Hughes, 1985).

6. The structural weaknesses in the Australian economy prior to reform were discussed by expert reviews such as the Vernon Committee Report (1965) and the Jackson Committee Report (1975). These findings are summarised in Productivity Commission (1999a), Box 1.

7. Significant tariff reductions on manufacturing imports were already implemented in 1973, along with reforms to improve efficiency in major export industries in the agricultural sector.

8. $\quad$ For a brief discussion of the significant impact of macroeconomic policy settings on output per capita across countries as well as in the Australian context see the 2003 OECD Economic Survey of Australia, Chapter II.

9. For example, during the 1990s, Australia's annual GDP per capita growth rate, at constant prices, averaged $3.6 \%$, up from $1.5 \%$ over the 1970 s and 1980s. This compares with $3.2 \%$ in the United States, $2.3 \%$ in the United Kingdom and $1.9 \%$ in both Germany and France.

10. PPPs are defined as the rates of currency conversion that equalise the purchasing power of different currencies by eliminating the differences in price levels between countries. In other words, PPPs are price relatives which show the ratio of the prices in national currencies of the same good or service in different countries.

11. Multifactor productivity is defined as the difference between the growth of output and those of the growth of inputs of capital and labour, suitably weighted. The capital/labour ratio is interpreted as an indicator for the "capital deepening" of the production process. Assuming a Cobb-Douglas specification of an aggregate production function and constant returns to scale, labour productivity growth can be represented as the sum of the growth of multifactor productivity and the change in the capital/labour ratio.

12. The market sector excludes activities which are not valued in the market. The sectors excluded are: property and business services; government administration and defence; education; health and community services; and personal and other services, including ownership of dwellings. In recent years, the market sector accounted for a little less than two-thirds of GDP. Over the past three decades, increased multifactor 
productivity accounted for around two-thirds of the $80 \%$ rise in per capita incomes in Australia, the rest being due to increased inputs of labour and capital.

13. See Parham (2004), Productivity Commission (2002a), Parham (2002a), Parham (2002b), Bean (2000), Dowrick (2000), Forsyth (2000), Productivity Commission (1999a), and the 2001 and 2003 OECD Economic Surveys of Australia.

14. For further examples of cost and price reductions in infrastructure services during the 1990s see Productivity Commission (1999a) and the 2001 OECD Economic Survey of Australia, Table 17.

15. See the 2001 OECD Economic Survey of Australia, Box 3.

16. It should be noted, though, that no country in the sample is the technological leader in all sectors.

17. Price differentials provide only an indirect indication of the degree of competition. For example, a price difference in a given sector may not necessarily be due to a competition problem in the sector, but to the induced effect of high prices in other industries. Price comparisons are also biased by differences in distribution and transport margins and indirect tax across countries (Pilat 1996). However, VAT (or GST) rates are lower in Australia than in most OECD countries.

18. This is because wages in low-productivity service sectors may be determined by wages in high-productivity manufacturing sectors, resulting in relatively high prices for services. Since the relative demand for services tends to rise with per capita income, higher income countries will tend to have systematically higher price levels than lower income countries.

19. The study applied a time-varying indicator of the regulatory stance in seven network industries from 1978 to 1998 to represent the evolution of the general regulatory framework in individual countries. Although the speed of progress varied, substantial regulatory reforms were implemented in all OECD countries over this period, increasing individual countries' employment rates by an average of $1 \frac{1}{2}$ and up to around $2 \frac{1 / 2}{2}$ percentage points where reforms have been pursued most vigorously.

20. Experience in other jurisdictions shows that when such issues arise in private litigation involving complaints by competitors, courts may narrow interpretations in order to avoid finding liability in cases where the motivation of the parties may not be consistent with the public interest.

21. See Hilmer et al. (1993).

22. The National Competition Council is an independent authority, which provides national oversight of the NCP in order to "help raise the living standards of the Australian community by ensuring that conditions for competition prevail throughout the economy which promotes growth, innovation and productivity".

23. This Act also formed the Australian Competition and Consumer Commission (ACCC), which is an independent statutory authority whose main tasks are to administer the Trade Practices Act and Prices Surveillance Act.

24. The most significant areas of non-compliance for the Commonwealth include legislation on wheat marketing, broadcasting and postal services, and the incomplete review and reform of health-related legislation and legislation on industry assistance (see NCC 2003a).

25. Short, Swan, Graham and Mackay-Smith (2001).

26. Productivity Commission (2002a).

27. National Competition Council (2003a).

28. 1 terajoule equals 1012 joule which in the case of gas equals about 26300 cubic metres.

29. National Competition Council (2003a), p. xiii.

30. Dryland salinity (a process whereby salt builds up in the soil) reflects changes in land use, i.e. the clearance of mature vegetation (trees and shrubs) and its replacement by shallow-rooted annual crops that use less water so gradually raising the water table to the level of natural salt deposits. Dryland salinity stems from reduced water use while wetland salinity results form increased water use. A discussion of the salinity problem is in the special chapter on "Enhancing environmentally sustainable growth" in the 2001 OECD 
Economic Survey of Australia. See also the section on "Sustainable development" in Chapter IV of the 2003 OECD Economic Survey of Australia.

31. National Competition Council (2003a), p. xiv.

32. In Victoria, for example, permanent water transfers increased during the 1990s, to almost 1 per cent of the total volume of water entitlements in 2000-01. In recent years, temporary trade ranged between 3 to $8 \%$ of total water entitlements, depending on climatic conditions. See National Competition Council (2003c).

33. National Competition Council (2003d).

34. The National Competition Policy agreements do not include specific arrangements for rail reform. However, rail services are subject to all of the general provisions of the Competition Principles Agreement, which has generated significant reform in the rail sector. State access regimes are facilitating competition in rail haulage operations, especially in bulk haulage operations.

35. Some of the gap in productivity level is due to factors that inherently disadvantage Australia, such as scale of operation. Technical efficiency is adjusted for such effects.

36. Freight rates are measured as the average selling price of freight services - total freight revenue divided by net tonne-kilometre.

37. The structure of Australia's aviation market has changed markedly in the recent years. Virgin Blue commenced operations in Australia in August 2000. In September, only days after the terrorist attacks on United States, Ansett Airlines was placed in the hands of an administrator and reduced operations before ceasing operations all together in early 2002. The demise of the airline, which held $39 \%$ of the domestic air travel market, allowed Qantas to raise its domestic market share from $55 \%$ to more than 80 per cent shortly after Ansett's failure. The obvious risk of Qantas taking advantage of its dominant position appears not to have materialised, though. Since the Ansett bankruptcy, Virgin Blue, number two in domestic air passenger transport, has clawed back market shares from Qantas. Virgin Blue's domestic fleet has grown from 22 aircraft in June 2002 to 33 in June 2003, and a further six were added in the third quarter that year.

38. In 1997, the Commonwealth Government commenced the sale to private operators of long-term leases for 17 of the 22 airports operated at the time by the Federal Airports Corporation (FAC). The remaining five federal airports - the four Sydney basin airports and Essendon Airport - were leased but not privatised, with their ownership transferred to two wholly Government-owned companies in 1998. The FAC subsequently ceased operation. Subsequently, Essendon Airport was sold in September 2001. The Sydney Airport sale was completed the next year, as was the sale of the three other Sydney basin airports.

39. Doove et al (2001) extend the research done by the OECD (Nicoletti et al, 2000) and find that there is a positive relationship between regulation and telecommunication prices, although not very strong. In Benefits Resulting from Changes in Telecommunications Services (2002) the Allen Consulting Group models that the net impact from the telecommunications industry reform has been a significant boost to GDP. In 1997-98, national output was $0.14 \%$ higher than it would have been had the changes to the telecommunications market not been introduced. Thereafter, the output dividend has grown each year, rising to $1.62 \%$ above the case of no change by $2001-02$.

40. This means that the network provider must provide local loop network services unbundled from their other services. If the local loop is unbundled then there will be a separate tariff just for this item.

41. The grocery industry includes a range of different operational structures, such as one-stop shops, national convenience retail stores, and specialist operations, including fruit and vegetable and meat outlets (Australian Competition and Consumer Commission, 2004).

42. With exception of Western Australia, all jurisdictions have significantly deregulated shop trading. See National Competition Council (2003b) for a detailed review on the legislative restrictions in the retail sector.

43. The National Association Grocers of Australia (NARGA) proposed that the market share of each major chain to be capped at $25 \%$, with divestiture taking place within 5 years in case that a chain surpasses this limit (Commonwealth of Australia, 1999). 
44. In June 2003, Coles Myer Ltd had advised the ACCC of its plan to acquire 12 independent supermarket outlets (ACCC, 2004).

45. Section 50 of the Act prohibits a merger if it would have, or be likely to have the impact of substantially lessening competition in a substantial market.

46. Few professions in Australia are entirely self-regulated nowadays. Rather, the majority of them are "co-regulated", with the statutory rules complemented by professional codes of conduct. For a discussion for the advantages and limitations of self-regulated schemes, see Deighton-Smith et al., 2001.

47. See, for example, Nguen-Hong (2000), Paterson et al. (2003), and OECD (2004).

48. For a discussion, see National Competition Council (2003a, d).

49. According to NCC, there has been a call for reforms of professional indemnity insurance arrangements in response to recent increases in premium and the collapse of the United Medical Protection. The Royal Australasian College of Surgeons, for instance, proposed the establishment of a monopoly supplier of professional indemnity insurance for medical practitioners (NCC, 2003b).

50. A recent study by the Productivity Commission (PC) on workers compensation arrangements and occupational health and safety, which examines issues similar to those affecting legal professional indemnity insurance, concludes that the literature does not provide clear evidence in favour of either public monopoly or competitive private provision for workers' compensation insurance. However, the PC deemed that, on balance, private provision was preferable to the public monopoly one because private capital is directly at risk; competition in the insurance market encourages greater innovation and efficiency; and that there is greater transparency of any governmental influence over premiums (PC, 2004b).

51. For a review, see National Competition Council (2003a,d).

52. Friendly Societies are owned by their Members, they are non-profit companies, and provide financial and other services.

53. Ownership rules for dental practices still apply in South Australia and Western Australia.

54. The next paragraphs, which deals with TCF and automotive assistance, are largely based on Productivity Commission (2003d), Review of TCF Assistance and Productivity Commission (2002b), Review of Automotive Assistance

55. Tariffs on apparel and certain finished textiles are to be reduced from $25 \%$ to $17.5 \%$. Tariffs on cotton sheeting, woven fabrics, carpets and footwear are to be reduced from 15 per cent to 10 per cent, and sleeping bags, table linen, tea towels and footwear parts will see a tariff reduction from $10 \%$ to $5 \%$. Tariffs on items currently at 5 per cent will not change.

56. The tariff rate for clothing and finished textiles will be reduced from 17.5 per cent to 10 per cent while the tariff rate for all other items will become 5 per cent.

57. See National Competition Council (2004).

58. See National Competition Council (2004).

59. See National Competition Council (2003a).

60. Productivity Commission (2004a).

61. Draft legislation which sought to reduce Australia Post's reserved service and to open the postal market to increased competition was withdrawn from the Parliament in early 2001 as it did not attract sufficient support.

62. See National Competition Council (2004). 
ECO/WKP(2005)38

\section{BIBLIOGRAPHY (for main text and Annexes)}

Ahn, S. and P. Hemmings (2000), "Policy Influences on Economic Growth in OECD-countries: An evaluation of the Evidence", OECD Economics Department Working Paper, No. 246.

Ahn, S. (2002), "Competition, Innovation and Productivity Growth: A Review of Theory and Evidence", OECD Economics Department Working Papers, No.317.

Australian Competition and Consumer Commission (ACCC) (2003), "Emerging market structures in the communications sector", A report to Senator Alston, Minister for Communications, Information Technology and the Arts.

Australian Competition and Consumer Commission (2004), 'Assessing Shopper Docket Petrol Discounts and Acquisitions in the Petrol and Grocery Sectors', http://www.accc.gov.au/content/index.phtml/itemId/486954

Australian Rail Industry: Overview and Issues (2003), by Affleck Consulting Pty Ltd, for the National Road Transport Commission, January.

Banks, G. (2003), "Gaining from trade liberalisation: Some reflections on Australia's experience", a presentation by the Productivity Commission chairman to the IIBE\&L/CEDA Conference, New Horizons in Trade: The WTO Round and Australia's Free Trade Negotiations, Adelaide Convention Centre, 5 June 2003.

Barnes, P. and S. Kennard (2002), "Skills and Australia's Productivity Surge", Productivity Commission Staff Research Paper, October.

Benefits Resulting from Changes in Telecommunications Services (2002),by The Allen Consulting Group Pty Ltd, forAustralian Communications Authority, October.

Bhagwati, J. (2002), Free Trade Today, Princeton University Press, Princeton and Oxford.

Bean, C. (2000), “The Australian Economic 'Miracle': A View from the North”, in: Gruen, D., and S. Shrestha, eds. (2000).

Boylaud, O. (2000), "Regulatory Reform in Road Freight and Retail Distribution", OECD Economics Department Working Papers, No. 255.

Boylaud, O. and G. Nicoletti (2001), "Regulatory Reform in Retail Distribution", OECD Economic Studies, No. 32.

Bradford, S. (2003), "Paying the Price: Final Goods Protection in OECD Countries", Review of Economics and Statistics, Vol. 85.

Brenchley, F. (2003), Allan Fels, Milton. 


\section{ECO/WKP(2005)38}

Commonwealth of Australia (1999), "Fair Market or Market Failure: A Review of Australia's Retailing Sector", Report by the Australian Parliament's Joint Select Committee on the Retailing Sector, Commonwealth of Australia http://www.aph.gov.au/senate/committee/retail_ctte/report/contents.htm.

Council of Australian Governments (COAG) Energy Market Review (2002), Towards a truly national and efficient energy market, Canberra (also known as Parer Review).

Deighton-Smith R., Harris B., and K. Pearson (2001), "Reforming the Regulation of the Professions", National Competition Council (NCC) Staff Discussion Paper, AusInfo, Canberra.

Doove, S., O. Gabbitas, D. Nguyen-Hong and J. Owen (2001), Price Effects of Regulation: Telecommunications, Air Passenger Transport and Electricity Supply, Productivity Commission Staff Research Paper, AusInfo, Canberra.

Dowrick, S. (1998), "Explaining the Pick-Up in Australian Productivity Performance", in: Productivity Commission and Australian National University.

Dowrick, S. (2000), The Resurgence of Australian Productivity Growth in the 1990s: Miracle or Mirage?, Paper presented to the $29^{\text {th }}$ Annual Conference of Economists.

Filmer, R., and D. Dao (1994), Economic Effects of Microeconomic Reform, EPAC, Background Paper No. 38.

Forsyth, P. (2000), "Microeconomic Policies and Structural Change", in: Gruen, D., and S. Shrestha, eds. (2000).

Gretton, P., J. Gali and D. Parham (2003), The effects of ICTs and complementary innovations on Australia's productivity growth, Productivity Commission, July.

Gretton, P., J. Gali and D. Parham (2002), Uptake and Impacts of ICTs in the Australian Economy: Evidence from Aggregate, Sectoral and Firm levels, Paper prepared from the Workshop on ICT and Business performance, 9 December 2002, OECD, Paris.

Gruen, D., and S. Shrestha, eds. (2000), The Australian Economy in the 1990s, Proceedings of a Conference, Reserve Bank of Australia, Sydney.

Hilmer, F.G., M. Rayner and G. Taperell (1993), "The Independent Committee of Inquiry", National Competition Policy, AGPS, Canberra..

Hughes, H. (1985), "Australia and the World Environment - the Dynamics of International Competition and Wealth Creation", in: J.A. Scutt (ed.), Poor Nation of the Pacific: Australia's Future, Sydney.

Industry Commission (1995), The Growth and Revenue Implications of Hilmer and Related Reforms: A Report by the Industry Commission to the Council of Australian Governments, Canberra, AGPS, March.

Jackson Committee to Advise on Policies for Manufacturing Industries (1975), Policies for Development of Manufacturing Industries, Vol. 1, Report to the Prime Minister, AGPS, Canberra.

Johnston, A., D. Porter, T. Cobbold and R. Dolamore (2000), Productivity in Australia's Wholesale and Retail Trade, Productivity Commission Staff Research Paper, AusInfo, Canberra. 
Le Fouler, L., W. Suyker and D. Turner (2001), "Trade linkages and the trade matrices in the OECD interlink model”, OECD Economics Department Working Papers, No. 310.

Marks, A. and M. Sadeghi (1998), "Testing the Olson Hypothesis Within the Australian Context", The Australian Economic Review, Vol. 31, No. 2, June.

National Competition Council (NCC) (2000a), Reform of the Legal Professions, Community Information, Melbourne.

National Competition Council (2000b), Reform of Health Care Professions, Community Information, Melbourne.

National Competition Council (2001a) Framework for the Third Tranche Assessment of Governments' Progress with Implementing National Competition Policy and Related Reforms, AusInfo, Canberra.

National Competition Council (2001b) Assessment of governments' progress in implementing national competition policy and related reforms, AusInfo, Canberra.

National Competition Council (2002a), Annual Report 2001-2002, AusInfo, Canberra.

National Competition Council (2002b) Assessment of Governments' Progress in Implementing the National Competition Policy and Related Reforms: Volume One-Assessment, AusInfo, Canberra. (August).

National Competition Council (2003a), Assessment of governments' progress in implementing the National Competition Policy and related reforms: 2003, Volume one - Overview of the National Competition Policy and related reforms, AusInfo, Canberra.

National Competition Council (2003b), Assessment of governments' progress in implementing the National Competition Policy and related reforms: 2003, Volume two - Legislation review and reform, AusInfo, Canberra.

National Competition Council (2003c), Assessment of governments' progress in implementing the National Competition Policy and related reforms: 2003, Volume three - Water reform, AusInfo, Canberra.

National Competition Council (2003d), Annual Report 2002-2003, AusInfo, Canberra.

National Competition Council (2004), Submission to the Productivity Commission Review of National Competition Policy Arrangements, Canberra, June.

National Transport Commission (2003), Strategic Plan 2004/05 to 2006/07, Melbourne.

Nguyen-Hong, D. (2000), "Restrictions on Trade in Professional Services", Productivity Commission Staff Research Paper, AusInfo, Canberra, August.

Nicoletti, G., S. Scarpetta and O. Boylaud (2000), "Summary indicators of product market regulation with an extension to employment protection legislation", OECD Economics Department Working Papers, No. 226.

Nicoletti, G., and S. Scarpetta (2003), "Regulation, Productivity and Growth: OECD Evidence", OECD Economics Department Working Papers, No. 347. 
OECD (1992), Economic Survey of Australia, Paris.

OECD (2002a), "Intra-industry and intra-firm trade and the internationalisation of production", Economic Outlook No. 71, June.

OECD (2002b), "The relationship between regional trade agreements and multilateral trading systems: The role of rules of origin", Working Party of the Trade Committee.

OECD (2003), The Sources of Economic Growth in the OECD Countries, Paris.

OECD (2004), Economic Survey of United Kingdom, Paris.

Owens, H. (2003), "Rail Reform Strategies: The Australian Experience", NBER, Working Paper 9592, Cambridge.

Parham, D. (2002 a), Australia's 1990s Productivity Surge and its Determinants, Paper presented at the Melbourne Institute/The Australian Conference: Towards Opportunity and Prosperity, Melbourne, April.

Parham, D. (2002 b), Productivity Growth in Australia: Are we enjoying a miracle?, Paper presented to the Communications Research Forum, Canberra, October.

Parham, D. (2002 c), Microeconomic Reforms and the Revival in Australia's Growth in Productivity and Living Standards, Paper presented to the Conference of Economists, Adelaide, October.

Parham, D. (2004), "Sources of Australia's Productivity Revival”, Economic Record, forthcoming.

Parham, D., P. Barnes, P. Roberts and S. Kenneth (2000), Distribution of the Economic Gains of the 1990s, Productivity Commission Staff Research Paper, AusInfo, Canberra. .

Parham, D., P. Roberts and H. Sun (2001), Information Technology and Australia's Productivity Surge, Productivity Commission Staff Research Paper, AusInfo, Canberra.

Paterson, I., M. Fink and A. Ogus (2003), "Economic Impact of Regulation in the Field of Liberal Profession in Different Member States", Institute for Advanced Studies, Vienna.

Pilat, D. (1996), "Labour productivity levels in OECD countries: Estimates for manufacturing and selected service sectors", OECD Economics Department Working Papers, No. 169.

Productivity Commission (PC) (1999a), Impact of Competition Policy Reforms on Rural and Regional Australia, Report No. 8, AusInfo, Canberra.

Productivity Commission (1999b), Microeconomic Reforms and Australian Productivity: Exploring the Links, Commission Research Paper, November, AusInfo, Canberra.

Productivity Commission (1999c), Progress in Rail Reform, Inquiry Report No. 6, AusInfo, Canberra.

Productivity Commission (2000a), Review of Legislation Regulating the Architectural Profession, Report No. 13, AusoInfo, Canberra, August.

Productivity Commission (2000b), Broadcasting, Report No. 11, AusInfo, Canberra. 
Productivity Commission (2001a), Review of the National Access Regime, Report No. 17, AusInfo, Canberra.

Productivity Commission (2001b), Telecommunications Competition Regulation, Report No. 16, Ausinfo, Canberra.

Productivity Commission (2002a), Trends in Australian Infrastructure Prices 1990-91 to 2000-01, Performance Monitoring, AusInfo, Canberra, May.

Productivity Commission (2002b), Review of Automotive Assistance, Report No. 25, Canberra.

Productivity Commission (2002c), Price Regulation of Airport Services, Report No. 19, AusInfo, Canberra.

Productivity Commission (2003a), Review of the Gas Access Regime, Draft Report, Canberra.

Productivity Commission (2003b), Trade and Assistance Review 2002-03, Annual Report Series 2002-03, Canberra.

Productivity Commission (2003c), Rules of Origin under the Australia-New Zealand Closer Economic Relations Trade Agreement, Interim Research Report, Canberra.

Productivity Commission (2003d), Review of TCF Assistance, Report No. 26, Canberra.

Productivity Commission (2004a), Review of National Competition Policy Arrangements, Productivity Commission Issues Paper, April.

Productivity Commission (2004b), National Workers' Compensation and Occupational Health and Safety Frameworks, Report No. 27, Canberra, March.

Productivity Commission (2004c), Review of National Competition Policy Reforms, Productivity Commission Discussion Draft, October.

Productivity Commission (2004d), Review of the Gas Access Regime, Report No. 31, Canberra, June.

Quiggin, J. (2000), “Discussion” in: in: Gruen, D., and S. Shrestha, eds. (2000).

Quiggin, J. (2001), “The Australian Productivity Miracle: A Sceptical View”, Agenda, Vol. 8, No. 4.

Review of National Road Transport Act 1991 (2002), by Affleck Consulting Pty Ltd and Meyrick \& Associates Pty Ltd, for the Australian Transport Council, July 2002.

Scarpetta, S. and T. Tressel (2002), "Productivity and convergence in a panel of OECD industries: do regulations and institutions matter?" OECD Economics Department Working Papers, No. 342.

Short, C., A. Swan, B. Graham and W. Mackay-Smith (2001), Electricity Reform: the Benefits and Costs to Australia, ABARE paper presented at the OUTLOOK 2001 Conference, Canberra, 27 February 1 March.

Snape, R., J. Adams and D. Morgan (1993), Regional Trade Agreements: Implications and Options for Australia, Department of Foreign Affairs and Trade, AGPS, Canberra. 


\section{ECO/WKP(2005)38}

Status Report of the Progress of Rail Reform in Australia. Executive Summary (2001), by ACIL Consulting, for the National Transport Secretariat, August.

Vernon Committee of Economic Enquiry (1996), Report of the Committee of Economic Enquiry, Commonwealth of Australia, Canberra.

Wooden, M. (2003), “Long-Hours Working and Enterprise Bargaining”, Agenda, Vol, 10, No. 3. 
ECO/WKP(2005)38

\section{ANNEX A1 COMPETITION POLICY INSTITUTIONS}

1. Australia's competition law is a complex combination of general principles and particular detailed prohibitions. It is the product of a long evolution. Australia first adopted a competition law in 1906, but constitutional weaknesses and court interpretations limited its scope and undercut its effectiveness. While the competition law was largely unused, high concentration and industry co-ordination behind tariff-wall protection characterised the Australian economy for much of the $20^{\text {th }}$ century. After some unsuccessful attempts at reform, the Trade Practices Act 1974 finally placed competition law on a sounder constitutional footing. The institutional structure took its present form in 1995, when the ACCC was created, as part of the Hilmer Commission's NCP reforms, by consolidating the Price Surveillance Authority into the Trade Practices Commission and adding consumer protection authority to the mix.

2. The TPA covers -competition law, consumer protection, and regulation of network monopolies. The ACCC, an independent statutory authority, has unusually wide-ranging authority. It is principally responsible for enforcement of competition and consumer protection law and for deciding about terms and prices for access to essential facilities. The ACCC has been active in promoting competition in telecommunications, broadcasting and energy. The Australian Competition Tribunal (Tribunal) is the appeal body for review of the ACCC's decisions about authorizations and access to essential facilities. The States and Territories have the power to apply their own laws about competition and sectoral regulation, but the competition provisions of Part IV of the TPA apply uniformly through all jurisdictions and are enforced by the ACCC. The National Competition Council (NCC), which does not have a direct law enforcement role, was created to oversee the implementation of the inter-governmental reform agreements and commitments that are embodied in the National Competition Policy; in addition, the NCC has some formal responsibilities in the system for making recommendations on applications for access to essential services. Another independent statutory authority, the Productivity Commission, undertakes public inquiries and advises about microeconomic policy and regulation. The Department of the Treasury oversees all of these independent entities and is responsible for policy. The Treasurer has some power to direct the ACCC to undertake certain work, but not in the handling of particular enforcement matters. Members of the independent bodies serve under conditions that protect their independence, but the process of appointment of a member of the ACCC must be supported by a majority of governments (that is, the states and territories and the commonwealth). Keeping enforcement decisions independent from political influence is ultimately guaranteed by the role of the courts. Only the courts can issue binding orders and impose financial penalties against violations.

3. The ACCC, with a broad range of responsibilities, is a large and prominent institution. It has 7 full-time members and 4 associates, plus 4 ex-officio members who are economic regulators from other federal, state and territorial bodies, supported by a staff of about 465 . The ACCC decides applications for authorisation, accepts notifications and undertakings, investigates complaints and initiates civil actions in court to obtain orders and penalties against violations. Several of the Dawson Committee's recommendations address controversies over the extent and exercise of the ACCC's powers. The most practical one is to set a deadline of 6 months for ACCC decisions on non-merger authorisation, assessed on the basis of public benefit. It has been difficult for parties to use the authorisation process because of delays and because of a belief that the ACCC would rarely if ever approve an application. Applicants can appeal to the Tribunal if the ACCC denies their application, but they cannot appeal until the ACCC has made a decision. The ACCC took over a year to decide an application in 1998-99. But the average time 
dropped to 6 months in 2001-02 and under 4 months in 2002-03, and the number of applications and decisions increased. Setting a deadline will not change current practice very much, but it will limit how the ACCC could use delay as a bargaining lever. In addition, the Dawson Committee proposed some useful technical improvements in the ACCC's investigative powers, notably to empower the ACCC to search and take possession of evidence (pursuant to a warrant issued by a magistrate). But it rejected the claims that the ACCC needed new power to issue interim relief, on the grounds that the courts could do so in appropriate cases. This is probably sound, but there is a risk of unacceptable delay if a court that is unfamiliar with competition issues founders over complexities in what should be a rapid, summary process. Some of the recommendations to curb the ACCC would have created a bureaucratic tangle of potentially competing overseers and ombudsmen; the government has not pursued them. The government has endorsed the Committee's recommendations to lower the ACCC's media profile, by supporting a policy of "no comment" on its investigations and limiting descriptions of its court proceedings to ensure that descriptions of court decisions are "consistent with the sole objective of ensuring public understanding of the court's decision".

4. The TPA's rules about restrictive agreements are based on sound broadly applicable principles which are reflected in legislation that can sometimes be complex and detailed. Legislation drafted in such detail requires adjustment when its rules inadvertently discourage or prevent efficient business strategies. The Dawson Committee proposals to correct some of these effects, for example by applying an economically-informed test of actual competitive effects to "third line forcing" rather than prohibit them per se (subject to the possibility of authorisation) and to provide a defence for joint ventures against per se prohibitions where they do not substantially lessen competition, are sound.

5. Nearly all of the economy is now subject to general competition law, thanks in substantial part to the NCP process. A key element of the NCP has been an ambitious, sustained programme to reduce regulation which unnecessarily restricts competition. It involved systematic review of existing legislation and controls on new legislation, applying to each a general presumption that legislation should not restrict competition unless it can be demonstrated that the benefits of the restriction to the community as a whole outweigh the costs, and that the objectives of the legislation can only be achieved by restricting competition. The federal constitutional structure posed particular challenges in designing and implementing this process. The formal allocation of constitutional powers limits what the commonwealth-level government can do directly about the behaviour of those who are not corporations. Conduct by individuals (such as professionals), by non-corporate bodies such as marketing boards operating within a state, and by state government entities is constitutionally subject to state-level authority. Broad, uniform coverage has been achieved principally through agreement among governments to co-ordinate and harmonise state and commonwealth legislation. To encourage change, the 1995 agreement creating the NCP provides for "competition payments" to states and territories. These are conceived as their share of additional revenues raised because of pro-competitive reforms. If an assessment from the NCC finds that reforms have lagged, though, the payment is to be reduced.

6. The NCP has tried to set controls in order to limit exemptions to the competition provisions of the TPA. To authorise or require anti-competitive conduct (that is, conduct that would otherwise violate the TPA), legislation must be explicit and specific, both about the conduct at issue and about the intention to create an exemption from the TPA. The government enacting it must notify the ACCC within 30 days after adoption. The law must be subject to regular review under the Competition Principles Agreement framework at least once every 10 years. In that review, the NCP's basic general test is to be applied: legislation is not to be retained unless the benefits to the community as a whole from the restriction on competition outweigh its costs. Regulations implementing any such legislation are subject to a 2 year sunset. 
7. At the commonwealth level, there are industry-specific regimes for telecommunications and ocean shipping and in addition there are exemptions for postal services and wheat exports. The conference-cartel ocean shipping system has been under challenge in most jurisdictions in recent years, although some form of special treatment for them remains common. Australia's retention of a broad exemption, despite its geographically inevitable dependence on cost-efficient ocean shipping services, is an anomaly.

8. A vast amount of legislation has gone through the NCP process. Of some 1800 laws reviewed between 1996 and 2003, nearly half were in the priority areas of water, primary industries, communications, fair trading and consumer protection, insurance and superannuation, health, legal and other professions, pharmaceuticals, planning and construction, retailing, social regulation and transport. But no government actually completed the process. Overall, about $70 \%$ of nominated laws were reviewed and reformed, but for the priority areas the percentage completed is substantially lower, at 56 per cent. Performance varies among governments, with some (including the Commonwealth itself) only completing 40 per cent or less of the priority legislation, while others completed nearly $80 \%$. (NCC 2003) The NCP system is to be reviewed by September 2005; in preparation, the PC is examining the impact of reforms to date and opportunities for significant gain through further reforms. The PC report is expected in early 2005.

9. The NCP also led to a novel, comprehensive approach to reforming traditional infrastructure monopolies. Its basic guiding principles included competitive neutrality for government business activities, structural reform of public monopolies as they are privatised and their markets are opened to competition, and independent oversight of pricing policies of government business enterprises. Procedures to facilitate access to monopoly infrastructure services are embodied in the "National Access Regime," a set of rules and institutions for dealing with problems encountered in many reform settings when potential new competitors need the services of the historical incumbent. In broad outline, the NCC and the relevant minister determine whether a particular "service" is "declared" to be subject to an access regime; when a service is declared, the ACCC then has the task of overseeing the design of the access rules and deciding disputes that arise. Complaints about denial of access to essential facilities are thus treated, appropriately, as analogous to complaints about refusal to deal by a firm with market power. It is not a one-size-fits-all system, as there are different regimes for different sectors. In some situations, regimes rely more on negotiation and arbitration, while others rely more on rules. The National Access Regime has been reviewed and should be retained with only relatively minor proposals for change to improve the Regime's focus and operation. 


\section{ANNEX A2 COMPETITIVE INDUSTRIES - SOME ASPECTS}

\section{Liquor licensing and petrol retailing legislation}

1. There are significant differences across the states in the legislation that controls liquor licenses. Overall, liquor laws designed to support the social standards of the community, such as minimum age for legal alcohol consumption, have not been questioned under the National Competition Policy (NCP) as they do not significantly affect competition. There are some regulations, however, for which a public benefit justification is required since they hamper competition in the liquor retailing market. Licensing laws often restrict the number of potential sellers, through, for example, the requirement in some jurisdictions of a "public needs test" for an additional liquor outlet in a specific area. In addition, in some states, legislation discriminates among different sellers of packaged liquor (favouring general license holders) and/or regulates the market conduct of license holders. ${ }^{63}$ Concerns have been raised by independent liquor outlets about the impact on competition from the ongoing expansion of major grocery retail chains in the market. The introduction of "warehouse" style liquor stores by the two major chains (and some independents) may also affect competition in the underlying market through lower prices on a wide variety of products (ACCC, 2004). In Victoria, the government introduced a package of measures to help independent liquor stores to remain competitive after the deregulation of the market in 2006. These include business advice and training to independent liquor stores, and financial support to programmes promoting the responsible sale of alcohol. In addition to liquor licensing laws, two jurisdictions - Western Australia and South Australia - have legislation that constrains competition in petrol retailing, with the underlying arrangements limiting freedom to set prices or precluding the entry of new sellers. Recent statistics suggest that the Australian packaged liquor industry is broadly competitive, with Metcash, ${ }^{64}$ Coles and Woolworth's accounting for 82 per cent of the market.

\section{Shopper docket petrol discounts}

2. "Shopper docket" schemes - binding petrol discounts to grocery purchases - have been feared as having the potential for enhancing the market power of the major chains, with long run adverse implications for competition and economic welfare. This issue - along with that of the acquisition of a number of independent supermarkets by a national grocery chain - was addressed in a recent inquiry by the ACCC. It decided to permit shopper docket discounts to continue, as it considered that there were "substantial benefits" for consumers arising from these schemes. These offers encourage competition and lower prices in the fuel market, while providing the incentives for retailers to become more innovative in non-price aspects (such as wider range of services) to acquire or retain their market share (ACCC, 2004). ${ }^{65}$

\section{Regulation of health and legal services}

3. Practice reservations, which permit only qualified or registered professionals to practice a profession, may be justified in cases that poor professional practice would expose consumers to significant risks, either in health or financial terms. However, such restrictions can also increase the cost of professional services, if they limit their availability. In this context, wide-ranging reservations of practice are likely to create distortions, as they may lead to an inappropriate restriction of some common low risk 
practices. ${ }^{66}$ The regulation of the legal profession provides an example in which broadly-defined practices restrict competition by inhibiting appropriately trained non-lawyer providers to enter the market. The state-level legislation makes it an offence for unqualified persons to provide legal services, reserving this right exclusively to registered legal practitioners. However, the definition of legal work - which differs across jurisdictions ${ }^{67}$ - is somewhat imprecise, making no clear distinction between services requiring comprehensive legal training and others, of less technical nature, which do not require such skills. In three jurisdictions, for instance, the practice of property transactions ("conveyancing") continues to be defined as legal work, while in the rest is permitted for non-lawyers in competition with legal practitioners. The opening up of the market in New South Wales has led to a 17 per cent decline of the services fees between the years 1994 and 1996. Competition concerns may also emerge from the method of practice reservation, and in particular in cases of restrictions on receiving financial reward for a task, in the absence of prohibition on performing the task, as this often implies a commercial objective rather than directly related to public protection.

4. Restrictions on business ownership arise from an alleged conflict between professional and commercial obligations, with some jurisdictions, in the case of health professions, prohibiting the employment of health practitioners by non-professionals, or requiring the owners of health care business in areas, such as dentistry or optometry, to be practitioners. Ownership restrictions cover pharmacy in all states (apart from the Northern Territory), with the underlying legislation further containing numerical restrictions on ownership, and preventing non-pharmacists from having pecuniary interests in a pharmacy. The Australian Government regulation also imposes restrictions, by regulating the number and location of pharmacies under the Pharmaceutical Benefits Scheme (PBS) (See Box A2.1). ${ }^{69}$ As for legal services, rules restricting business ownership require, in general, law firms to be owned by lawyers, permitting only lawyers to share in the profits. This restricts the ability of legal practitioners to share profits with non-lawyers, making it hard for them to form multidisciplinary practices with other professionals, such as accountants and management consultants.

\section{Box A2.1. The Australian Government health legislation and its impact on competition ${ }^{1}$}

The Australian Government regulates the health and pharmaceutical sector through legislation on the Medicare system - providing rebates for private sector medical services, free at point of service hospital care on the basis of need, and subsidised access to pharmaceuticals. The general objective of federal legislation is to ensure equitable geographical access to high quality and cost-effective health care, by regulating who can provide services that are eligible for Medicare or pharmaceutical benefits.

The key restrictions on competition contained in the Australian Government health legislation according to the 2003 NCP assessment report by the NCC - relate to:

- $\quad$ Medicare provider numbers: The Australian Government introduced legislation in 1996 that limits entry to private medical services, as it requires new medical graduates to complete additional training before they gain access to the register of a Medicare provider number. Legislation aims at improving the quality of general practice and promoting an even distribution of medical practitioners. The NCC assessed that the Australian Government has met its CPA obligations in relation to Medicare provider numbers. Changes to general practice training under the 2000 Budget were deemed to have reduced the extent to which restrictions on the Medicare numbers hamper competition.

- $\quad$ Pathology collection centre approvals: The Health Insurance Act 1973 restricts, under the licensed collection centre scheme, the number of pathology outlets that can provide services eligible for Medicare benefits, preventing entry to the market. One of the objectives of the scheme was to facilitate managing Medicare costs. The approved collection centre scheme, which replaced the licensed collection centre scheme in December 2001, retains restrictions on the number of collection centres that an approved pathology authority may operate. It however entails a partial deregulation of pathology collection centres, as the method for allocating approvals is based on pathology episode activity over a 12-month period, rather than the number of participants in the scheme. In its assessment report, the NCC considered that there is a public interest case for maintaining the new scheme (to be phased in four years from December 2001) until 2005 to realise its benefits, as its deregulation feature promotes competition. 
- $\quad$ Pharmaceutical Benefits Scheme (PBS) dispensing rights for pharmacies: The PBS is regulated by federal government legislation, supplemented by the Australian Community Pharmacy Agreement. The main intervention of the federal government in the pharmacy sector is through restrictions on the number and location of PBS-licensed pharmacies, designed to ensure an equitable distribution of pharmacies across the country and to contain PBS expenditure. The legislation also restricts approvals for relocations of existing pharmacies. The Wilkinson review (1999) recommended the removal of location restrictions for both new and relocating pharmacies from mid-2001, as there was no convincing evidence that such restrictions provide a net public benefit. The Australian Government argued, instead, for phased and targeted easing of the existing location rules, with an opportunity for their review during the period to the next Australian Community Pharmacy Agreement (commencing in July 2005). The NCC considered that there is a public interest case for phasing in reforms, but not for retaining the restrictions. It assessed that the Australian Government has met its CPA obligations with regard to pharmacy location restrictions, in view of the agreed, between the federal government and the Pharmacy Guild of Australia, review of these restrictions between over the period 2001-05.

- $\quad$ Restrictions on private health insurance: There are restrictions governing the private health insurance, including registration requirements for the funds and product and price controls. These regulations are aiming to encourage private funding of health services in Australia and ensure its accessibility to a large part of the population. Under the National Health Act and associated regulations, the Australian Government restricts, for instance, the services covered by private health insurance funds, and requires community rating of private health insurance. Such regulations however hamper competition among health funds, with adverse implications for consumer choice and business costs. Community rating, for example prevents, a premium differentiation by the insurers on the basis of sex, age, or health status, as every contributor pays the same premium. This implies, however, an increased burden for the younger and healthier members, who pay relatively more. The 'lifetime community rating' implemented in 2000 , amended community rating to allow a premium reflecting the age at entry for the new entrants. The NCC considers that the lifetime community rating may be consistent with the CPA principles, but it sees no clear longer-term net benefit arising from such scheme. To this end, it recommends a formal examination of this benefit through a review of the community rating principles.

1. The Box draws on NCC (2001a, 2002b and 2003b).

5. The usual justification for ownership controls is that they preserve professional independence, thus protecting the public from inappropriate commercial interference in decision making. There is limited evidence, however, that supports the link between ownership restrictions and the preservation of professional morals. ${ }^{70}$ Rather, such restrictions have the potential of imposing a cost on both consumers and professionals, through limiting the market entry for new providers and constraining innovation. Several jurisdictions took steps towards reducing inappropriate commercial influence on clinical-making decisions by making such interference an offence. While involving some costs of enforcement for the governments, such an approach evades the costs on the patients and health professionals stemming from ownership restrictions. An additional constraint on commercial behaviour regards advertising restrictions, sometimes considered as means to ensure that consumers are not misled by deceptive claims. Nevertheless such rules can potentially hamper competition by making it more difficult for new entrants to promote their business and for the consumers to make comparisons of the available services and prices. Review activity under NCP has generally seen a relaxation of advertising controls. But restrictions remain, raising competition issues. In the case of legal professions some new advertisement restrictions have been introduced recently in some jurisdictions in response to the increasing public liability insurance premiums (Deighton-Smith 2001; NCC 2001a, 2003b).

6. Competition in the area of health professions is further hampered by restrictions on the number of medical practitioners trained in Australia, as well as the limits on overseas-trained medical practitioners entering the country. The Australian Government determines the number of subsidised medical school places, while the availability of training places in various medical specialities is influenced by the workforce planning targets set by the Australian Medical Workforce Advisory Committee. Barriers for the overseas-trained professional to enter the practice arise from Australian migration requirements, and 
medical registration requirements. In addition to the likelihood of excluding competent practitioners, such restrictions have the potential of creating an "artificial" shortage of supply, with adverse consequences on heath care prices and the quality of services provided in terms of waiting times for the patients (NCC, 2000b).

\section{Other professions}

7. In addition to the health and legal professions, regulations limit competition in other areas of professions and occupations, although not to the same degree. These regulations include licensing or registration provisions for a range of occupations such as commercial and private inquiry agents, security service providers, driving instructors and others. There are differences across the states with regard to the licensing requirements, ranging from complex tests of practitioners' qualifications and character, to a "negative licensing scheme", not requiring applicants to be registered. An issue also emerges from the licensing or registration of certain occupations (including auctioneers, conveyancers, and employment agents) in some but not all jurisdictions, raising the question of the necessity of such regulations (NCC, 2003a). 


\section{ANNEX A3 AUSTRALIA'S CURRENT TRADE POLICY STANCE}

1. The general tariff on manufacturing goods has now fallen to 5 per cent. A $15 \%$ duty on passenger motor vehicles (PMV) and up to $25 \%$ duty on textile, clothing and footwear (TCF) ${ }^{71}$ pull up the average, although both these sectors will undergo further tariff reductions in 2005. Credit schemes that provide assistance for both the PMV and TCF industries are in effect. At the other extreme, imports such as food, books, medical and scientific equipment enter Australia duty-free. Of the remainder, the government levies a general tariff of 5\%. The average level of tariff protection to agriculture, $0.3 \%$, compares favourably with most other countries. This does not reflect the non-tariff barrier of the strict quarantine and inspection regime.

2. Some goods or countries receive special treatment. For those goods where the general tariff rate is 5 per cent and there is no Australian manufacturer of equivalent goods, a successful application of a tariff concession order will reduce the duty rate to $3 \%$ for business inputs and $0 \%$ for consumption goods. Additionally, a provision for duty-free entry exists if these goods also qualify as being for the use in the mining, minerals-processing, agriculture, food-packaging and food-processing industries. Further, Australia provides quota and duty-free access to all goods originating from Least Developed Countries recognised as such by the United Nations Conference on Trade and Development and East Timor. For New Zealand, Canada and Singapore, preferential duty rates apply to imports on the basis of bilateral trade agreements. Most goods imported from these countries are brought in duty free.

3. Quotas have been entirely abolished, but other non-tariff barriers still exist. Goods imported into Australia in contravention of the strict quarantine regulations are detained and may be forfeited. There are also strict controls on the correct labelling of imported goods. Anti-dumping and countervailing activity may be imposed where there is evidence that dumped or subsidised goods are causing significant injury to Australian industry. The number of Australian initiations of anti-dumping and countervailing cases has been relatively stable over the past five years, with 15 cases initiated in 2002-03. Cases initiated in 2002-03, all of which was antidumping actions, is almost three times that of 1994-95, but only around a quarter of the 1992-93 level. In 2001-02, Australia accounted for 5\% of the anti-dumping and countervailing cases initiated internationally. This made Australia the seventh largest user of anti-dumping and countervailing duties. The top three on this list was the United States, the European Union and India (Productivity Commission, 2003b). 
ECO/WKP(2005)38

\section{ANNEX A4 ASSESSING TRADE POLICY}

\section{The impact of trade liberalisation on Australia's economy}

1. This section suggests that when explaining Australia's impressive economic development since the 1990s, trade liberalisation is one important explanatory variable. In principle, the transmission between increased exposure to trade and economic growth can run through several channels. First, lower import prices translate into lower domestic prices and a once and for all boost to consumer welfare. Second, if trading partners also lower import barriers, higher exports boost output (if output is below capacity) and then export prices (and therefore better the terms of trade). Lastly, permanently increased competition on the domestic market can trigger innovation and greater efficiency, possibly helping to raise potential growth rates of GDP. Although rationales abound, modelling the impact of increased trade openness on underlying growth is a more troublesome exercise. Still, the general conclusion that can be drawn from recent empirical literature is that, on balance, the weight of evidence based on cross-country regressions supports the view that trade promotes growth. There is also some evidence that trade assists convergence in per capita income (see Ahn and Hemmings, 2000, for an overview of empirical studies).

2. The trade liberalisation process made a major step forward at the beginning of the 1970s with a 25 per cent across-the-board tariff cut on manufacturing imports, along with reforms to improve efficiency in major export industries in the agricultural sector (Box 3.A4.1). This was followed a decade later by other landmark reforms, when the internationalisation of the Australian economy was extended by floating the dollar and removing foreign exchange controls. Greater exposure to international competition created pressures for more efficient delivery of utility services and greater flexibility in factor markets.

\section{Box A4.1. A brief on Australia's trade policy evolution}

Along with the bevy of microeconomic reforms discussed in this paper, liberalising trade is thought to be an imperative factor when explaining how the sluggish Australian economy at last gained strength after the nadir around 1990. Reforms unfolded over the 1970s and especially the 1980s. Tariff reductions over the period have brought significant reductions in levels of effective assistance to import-competing industries. For example, the average effective rate for the manufacturing sector has declined from 35 per cent in 1972-73 to about 5\% for $2002-03$. However, progress over the period has not always been smooth, as depicted below. Further, other than for the PMV and TFC sectors and some recent FTAs, there have been no systematic reductions since 1996. The Productivity Commission (1999b) outlines the main steps in Australia's path towards a more liberal trade policy:

- In 1971, the Government announced a program of review of tariffs by the Tariff Board. The Government was careful to point out, however, that this would involve no commitment on its part to implement any recommendations made.

- In 1973, tariffs were reduced across the board by $25 \%$. In later public discussions, subsequent increases in unemployment were attributed primarily to these tariff cuts, against the evidence of analytical studies. Further across-the-board reductions were seen as politically difficult.

- Consequently, there was a return to the piecemeal approach. Non-tariff measures gained favour in response to increasing unemployment. Market sharing through import quotas was introduced as a 'temporary' measure in the mid-1970s, mostly in highly assisted industries (in two cases, they were not removed until 1988 (Automotive) and 1993 (TCF)). 
- In 1982, the Government announced that general reductions in protection were precluded for the time being.

- Governments adopted a broader industry-wide approach to reviewing industry assistance from the early 1980s. Industry plans were introduced in some industries from 1983, attempting to establish greater uniformity in assistance, improve intra-industry efficiency and instill an export focus. The Government increasingly determined industry development measures on a generic basis - for example, generally available encouragement of research and development.

- An agreement for Closer Economic Relations between Australia and New Zealand entered into force in 1983. It established a progressive move toward free trade in most goods between the two countries and has undergone three reviews, including widening the scope of the agreement to include the harmonizing of a range of non-tariff measures.

- In 1988, the Government announced a four-year program of phased reductions in nominal tariff rates for most imports (excluding the PMV and TCF sectors). Tariffs above 15 per cent were to be phased down to 15 per cent and those between 10 per cent and 15 per cent were to be phased down to 10 per cent.

- In 1991, the Government announced the continuation of this program of phased tariff reductions. General tariffs were to be phased down to 5 per cent over the four years to July 1996. Tariffs on passenger motor vehicles were to be phased down from 35 per cent in 1992 to 15 per cent in 2000. Tariffs on textiles, clothing and footwear were to be phased down to a maximum rate of 25 per cent by 2000 .

- In 1997, the Government announced that tariffs in the textiles, clothing and footwear industries and the automotive industries were to be frozen at their year 2000 levels until a further reduction in 2005.

- In 2002 and 2003 the Government announced further tariff reforms/reductions for the PMV and TCF sectors respectively.

- In 2003 Australia and Singapore signed an FTA, Australia's first since the FTA with New Zealand. Australia also signed a Trade and Economic Framework with China involving a commitment to undertake a joint feasibility study into a possible FTA between the two countries.

- In 2004, Australia and the United States signed an FTA, which is due to be brought into force on 1 January 2005. Australia also signed an FTA with Thailand in 2004, which is expected to come into force on 1 January 2005.

Source: Productivity Commission (1999b); OECD.

3. Trade has become an increasingly important part of the Australian economy, as for all other countries (Table A4.1). During the 1990s, trade openness (trade/GDP ratio) has increased somewhat more in Australia than for the OECD-average. Driving this development has been trade in goods, while trade in services has yet to become a significant contributor to economic growth. Second, total exports are heavily dependent on non-manufactured goods, ${ }^{72}$ and intra-industry trade is comparatively low. The low share of intra-industry trade reflects the tendency for a high proportion of Australia's manufactured exports to consist of relatively simple transformations of raw materials with which the country is well endowed, and that such transformations are not suited to division across different countries (OECD, 2002). Finally, this latter point is underpinned by the data on export ratios and import penetration, showing that high-tech industries clearly are the most integrated industries internationally. 
ECO/WKP(2005)38

Table A 4.1. Exposure to international trade competition in selected OECD countries ${ }^{1}$

Average of export ratio and import penetration

\begin{tabular}{lrr}
\hline & 1991 & 1999 \\
\hline Computers & 46.7 & 60.8 \\
Aircraft & 41.7 & 53.1 \\
Scientific instruments & 27.3 & 39.3 \\
Radio, TV, communications & 28.1 & 39.2 \\
Textiles, clothing & 24.7 & 35.3 \\
Machinery, equipment & 27.2 & 34.6 \\
Motor vehicles & 30.1 & 34.6 \\
Electrical machinery & 21.1 & 33.8 \\
Chemicals & 24.8 & 32.6 \\
Other transport & 31.5 & 31.5 \\
Pharmaceuticals & 16.4 & 27.4 \\
Total manufacturing & 19.7 & 25.8 \\
Shipbuilding & 22.4 & 24.3 \\
Basic metals & 19.0 & 22.8 \\
Other manufacturing & 15.6 & 22.2 \\
Rubber, plastics & 17.5 & 20.7 \\
Wood & 12.5 & 15.3 \\
Non-metallic minerals & 10.7 & 12.9 \\
Food, drink, tobacco & 9.8 & 11.8 \\
Petroleum refining & 12.5 & 11.8 \\
Metal products & 8.6 & 11.1 \\
Paper, printing & 9.8 & 10.9 \\
\hline
\end{tabular}

1. OECD includes Australia, Austria, Canada, Denmark, Finland, France, Germany, Ireland, Italy, Japan, Norway, Portugal, Spain, Sweden, the United Kingdom, the United States.

Source: OECD, STAN database, June 2003.

4. It is plausible that falling import protection has stimulated increased export orientation in Australia's manufacturing sector (Marks and Sadeghi, 1998). Importantly, notwithstanding the historically comparative advantage in the production of certain raw materials, opening up to trade seems to have sparked a process of change in the export composition. Traditional Australian exports of minerals and fuels and agricultural products still form a relatively large share of Australia's merchandise exports, but have fallen as a proportion of exports reflecting strong growth in exports of finished manufactures. Figure A4.1 illustrates the relationship between falling protection levels and growth in finished exports. Arguably, this reflects the fact that finished exports have become more competitive. Trade liberalisation has facilitated this outcome by providing industries with cheaper imported and domestic inputs. Australia's import penetration increased quite substantially in the 1990s, and dependency on imports for subsequent exports increased in the same period (Figure A4.2). At the end of the day, Australia has experienced a trend towards increasing the level of value added to Australia's raw material exports, boosting national income. 
Figure A4.1. Finished exports and protection

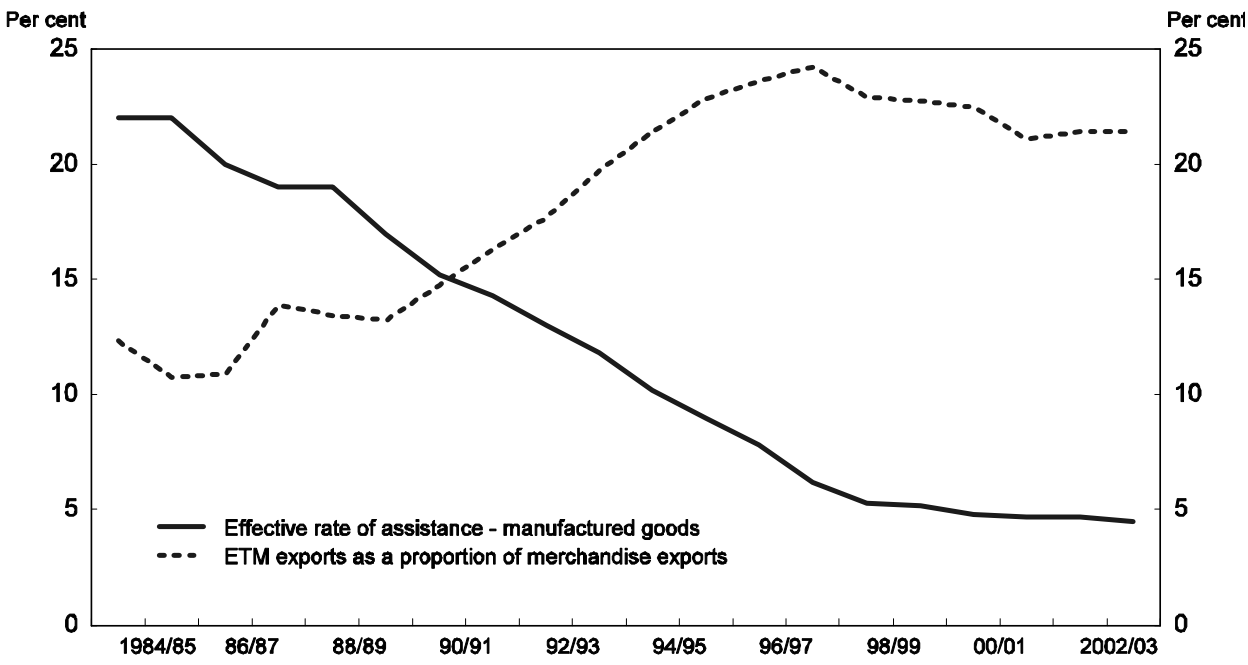

Source: Productivity Commission and Department of Foreign Affairs and Trade.

Figure A 4.2. Import contents of exports ${ }^{1}$

1980 and 1997

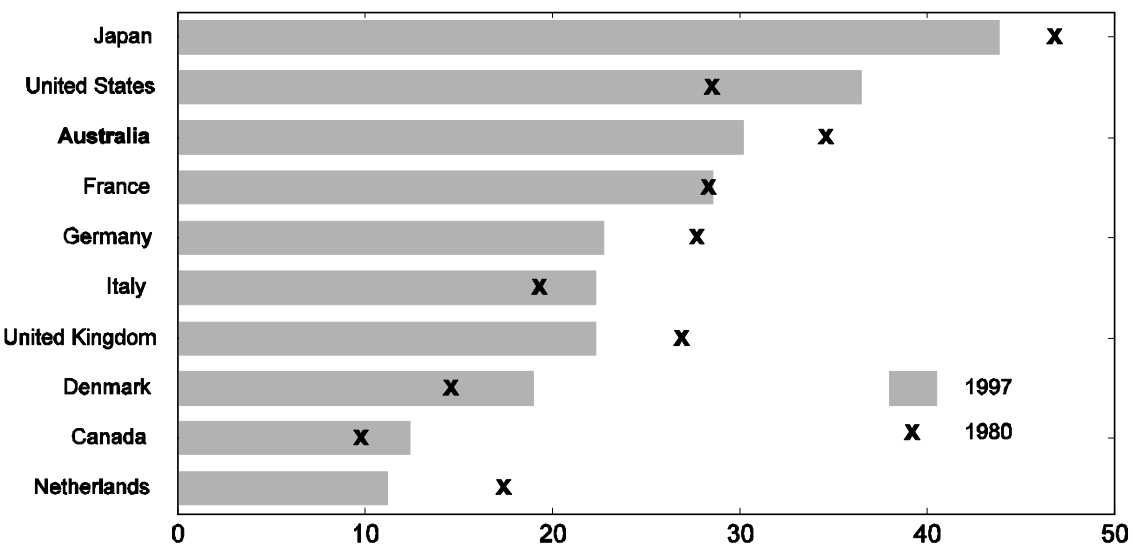

1. Defined as the share of imports used in production to make one unit of export, including energy. Source: OECD, Input-Output database, February 2003. 
5. As mentioned above, trade in services remains limited. As a share of GDP, trade in services only increased from $3.9 \%$ in 1990 to $4.5 \%$ in 2001 . Trade in goods increased from $12.7 \%$ to $17 \%$ over the same period. The relatively minor role for services in international trade, a general phenomenon, stands in stark contrast to the contribution of services in the domestic economies, where the proportion of total value-added contributed by services usually is around $70 \%$ and rising. Of course, services are more difficult to trade internationally, emphasising the importance of physical proximity between supplier and customer. Another reason may be that the service cannot be traded separately from its production. Consequently service producers may find it necessary to establish a commercial presence in countries they wish to trade in, in order to be close to their customers. Accordingly, foreign direct investment flows in the OECD-area have spiked during the 1990s, but Australia seems to have fallen short of the average trend (Figure A4.3). As in other OECD-countries, the fastest growing service exports and imports the last decade have been computer and information services (Figure A4.4). Imports of insurance and financial services have declined in the period, contrary to the OECD trend, indicating that outside pressure on domestic businesses is relatively limited in these sectors. On the other hand, imports of other services like legal services, accounting and management consulting has increased rapidly, although from low levels.

\section{Figure A 4.3. Outward foreign direct investments}

Average 1994-2001

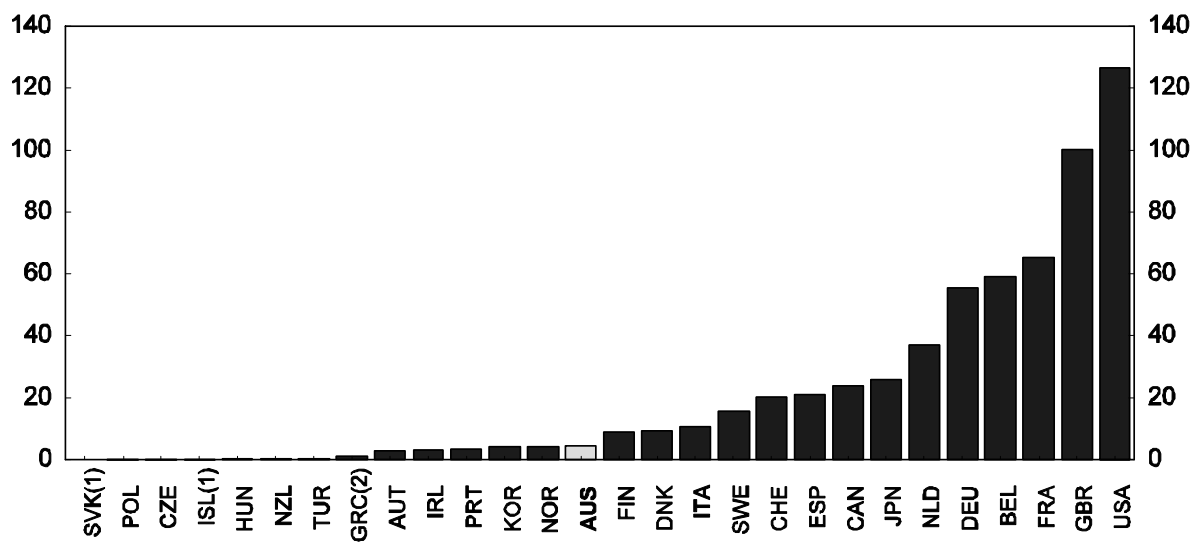

1. 1994-2000.

2. Excluding 1998.

Source: OECD (2003), Science, Technology and Industry: Scoreboard of Indicators. 
Figure A4.4. Average annual change in Australia's service trade

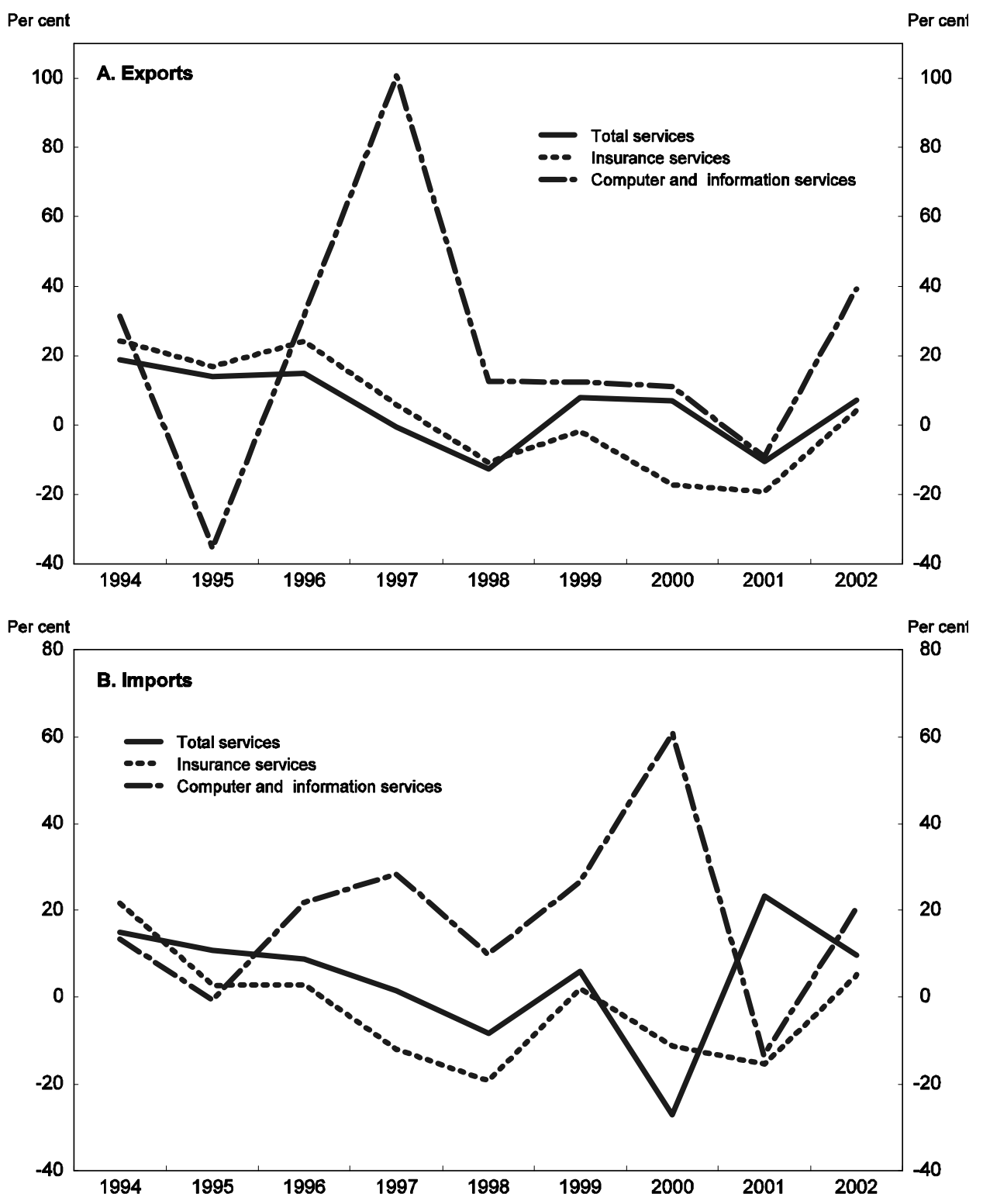

Source: OECD, Statistics on International Trade in Services.

\section{Is Australia shifting its approach towards trade liberalisation?}

6. Although Australia's average tariffs came down only recently in line with its industrial partners, it is nonetheless noteworthy that much of Australia's trade liberalisation policies have been unilateral, undertaken regardless of other countries' action. Such an approach reflects the recognition that the benefits of trade come more from opening the economy to cheaper imports, than waiting for other countries to open their markets. As a result, domestic productivity and resource allocation improves, paving the way for higher living standards, as well as making exports more competitive. Of course, there should be additional gains if foreign barriers decline as well, but the focus on getting "concessions" from trading partners during trade talks misses the point. 
7. While there are benefits to be collected both from unilateral and multilateral trade liberalisation, the case for regional or bilateral agreements is less clear cut. ${ }^{73}$ Whether such agreements will prove to be building blocks or stumbling blocks for wider liberalisation remains contested. What seem clear in the meantime, however, is that countries excluded from these agreements face considerable risks (Banks, 2003). Nonetheless, regional and bilateral trade agreements have been increasingly popular. Two decades ago, only 20 regional or bilateral trade agreements (PTA) were in force around the world, with the European Union being the major regional agreement. However, the number of PTAs has increased substantially over the past decade (Figure A4.5). By 2003, 273 of these agreements had been notified to the WTO. Australia follow suit. In February 2003, Australia and Singapore signed a free trade agreement (FTA), Australia's first since the two decade old Australia-New Zealand Closer Economic Relations Agreement. Australia also signed an FTA with Thailand in July 2004 and most recently has negotiated an FTA with the United States.

Figure A4.5. The evolution of Regional Trade Agreements in the world ${ }^{1}$

1948 to 2003

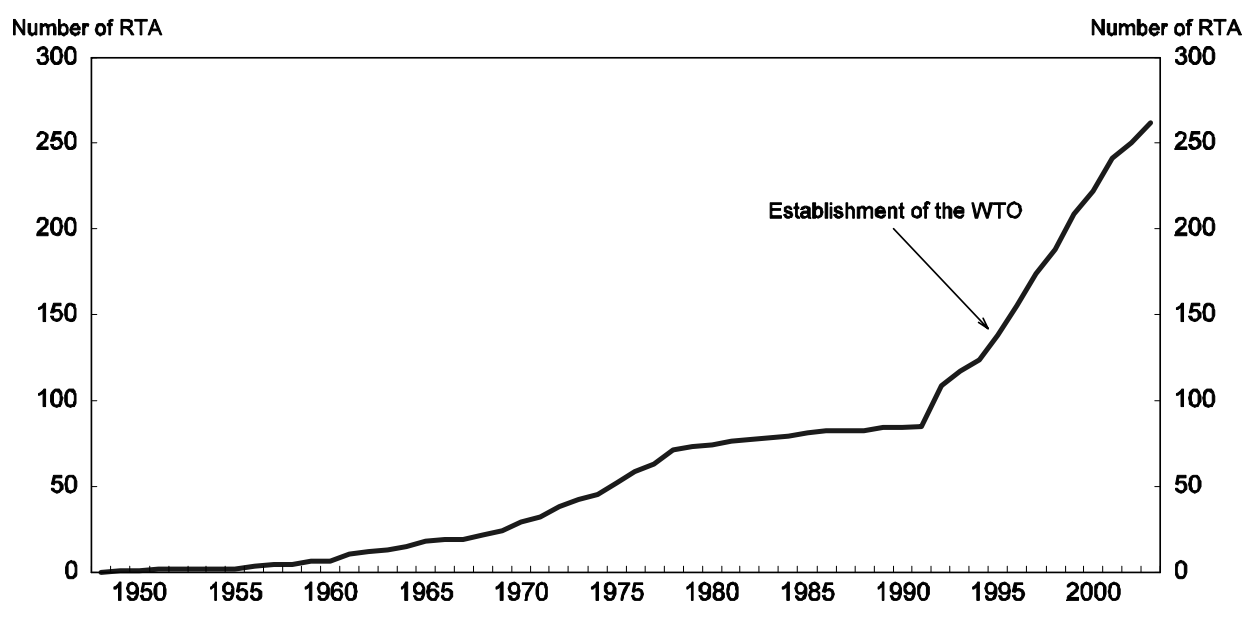

1. Regional Trade Agreements notified to the GATT/WTO, cumulative.

Source: World Trade Organisation. 


\section{NOTES}

63. According to the NCC, the reform of liquor laws that restrict competition has proved difficult to be implemented, with Victoria, the Australian Capital Territory and Tasmania being the only states having met their Competition Principles Agreement obligations in relation to liquor licensing by the time of the 2003 NCP assessment report by the Council (NCC 2003a and 2004). New South Wales has since reformed its liquor laws that restrict competition.

64. Metcash is Australia's largest independent grocery wholesaler, distributer of groceries, refrigerated goods and general merchandise to independent retails in all states (apart from Western Australia).

65. The shopper docket petrol discount schemes reviewed by ACCC relate to discounts offered by the two major chains Coles Myer Ltd and Woolworths Limited. Shopper docket discounts are a form of third line forcing, which is prohibited under the Trade Practices Act 1974 (TPA). However, immunity from legal action may be obtained by notifying the ACCC. The ACCC assesses third line forcing conduct notifications by weighting the potential benefits to the public against the particular detriments, particularly the anti-competitive one.

66. In some professions, such as the dental, different areas of practice are reserved to related professional and para-professional groups, with some services allowed to be provided by different types of para-professionals, while other, higher risk activities are reserved to dentists only (Deighton-Smith et al., 2001).

67. The definition of legal work varies across the states, but in general entails drawing or preparing wills or documents which affect rights between parties, impact real or personal property, or relate to legal proceedings, and probate work (NCC 2001b).

68. See, Deighton-Smith et al. 2001; and NCC (2001b and 2003a).

69. Both the federal and state governments regulate pharmacies. As with the other health professions the State and Territory pharmacy legislation includes entry standards, registration requirements, and reservation, as well as also reserved areas of practice and business conduct restrictions.

70. Following its review under NCP, the New South Wales derived the conclusion that the achievement of professional legal objectives requires focussing on the accountability of individuals rather than restrictions on ownership (NCC 2001a).

71. Tariffs on apparel and certain finished textiles are currently $25 \%$, while tariffs on cotton sheeting, woven fabrics, carpets and footwear are $15 \%$ and tariffs on sleeping bags, table linen, tea towels and footwear parts are $10 \%$.

72. For Australia, Iceland, New Zealand and Norway, non-manufactures were at least $40 \%$ of the total value of exports in 2000, more than double the world average, see Le Fouler et al. (2001).

73. See for example Snape, Adams and Morgan (1993), OECD (2002b), Bhagwati (2002) and Productivity Commission (2003c). 


\section{WORKING PAPERS}

The full series of Economics Department Working Papers can be consulted at www.oecd.org/eco/Working_Papers/

450. House Prices and Inflation in the Euro Area

(October 2005) Boris Cournède

449. The EU's Single Market: At Your Service?

(October 2005) Line Vogt

448. Slovakia's introduction of a flat tax as part of wider economic reforms

(October 2005) Anne-Marie Brook and Willi Leibfritz

447. The Education Challenge in Mexico: Delivering Good Quality Education to All (October 2005) Stéphanie Guichard

446. In Search of Efficiency: Improving Health Care in Hungary (October 2005) Alessandro Goglio

445. Hungarian Innovation Policy: What's the Best Way Forward? (October 2005) Philip Hemmings

444. The Challenges of EMU Accession Faced by Catch-Up Countries: A Slovak Republic Case Study (September 2005) Anne-Marie Brook

443. Getting better value for money from Sweden's healthcare system (September 2005) David Rae

442. How to reduce sickness absences in Sweden: lessons from international experience (September 2005) David Rae

441. The Labour Market Impact of Rapid Ageing of Government Employees: Some Illustrative Scenarios (September 2005) Jens Høj and Sylvie Toly

440. The New OECD International Trade Model (August 2005) Nigel Pain, Annabelle Mourougane, Franck Sédillot and Laurence Le Fouler

439. The French Tax system: Main characteristics, recent developments and some considerations for reform (July 2005) Willi Leibfritz and Paul O’Brien

438. The Effects of EMU on Structural Reforms in Labour and Product Markets (July 2005) Romain Duval and Jørgen Elmeskov

437. Product Market Competition andEconomic Performance in New Zealand (July 2005) Annabelle Mourougane and Michael Wise

436. Getting the Most out of Public Sector Decentralisation in Spain (July 2005) Isabelle Joumard and Claude Giorno

435. Sources of Inflation Persistence in the Euro Area (July 2005) Boris Cournède, Alexandra Janovskaia, Paul van den Noord

434. Measuring Cyclically-Adjusted Budget Balances for OECD Countries (July 2005) Nathalie Girouard and Christophe André 


\section{ECO/WKP(2005)38}

433. Product Market Competition and Economic Performance in the United Kingdom (June 2005) Maria Maher and Michael Wise

432. The Benefits of Liberalising Product Markets and Reducing Barriers to International Trade and Investment: the Case of the United States and the European Union (June 2005)

431. Boosting Growth through Greater Competition in Denmark (May 2005) Martin Jørgensen

430. Fifteen Years of Economic Reform in Russia: What Has Been Achieved: What Remains to be Done? (May 2005) Rudiger Ahrend and William Tompson

429. Assessing the OECD Job Strategy: Past Developments and Reforms (May 2005) Nicola Brandt, Jean-Marc Burniaux and Romain Duval

428. Ageing, Welfare Services and Municipalities in Finland (May 2005) Jens Lundsgaard

427. The Impact of Structural Policies on Trade-Related Adjustment and the Shift to Services (April 2005) Per Mathis Kongsrud and Isabelle Wanner

426. Product Market Competition and Economic Performance in Iceland (April 2005) Thomas Laubach and Michael Wise

425. Enhancing Brazil's Regulatory Framework for Network Industries: The Case of Electricity, Oil and Gas, and Water and Sanitation (April 2005) Edmar Almeida and Nanno Mulder

424. Education Attainment in Brazil: The Experience of FUNDEF (April 2005) Luiz de Mello and Mombert Hoppe

423. Estimating a Fiscal Reaction Function: The Case of Debt Sustainability in Brazil (April 2005) Luiz de Mello

422. Product Market Competition and Economic Performance in the Netherlands (April 2005) Maria Maher and Michael Wise

421. Product Market Competition and Economic Performance in Canada (April 2005) Maria Maher and Jay Shaffer

420. The Impact of Ageing on Demand, Factor Markets and Growth (April 2005) Joaquim Oliveira Martins, Frédéric Gonand, Pablo Antolin, Christine de la Maisonneuve and Kwang-Yeol Yoo.

419. Product Market Regulation in OECD Countries: 1998 to 2003

(February 2005) Paul Conway, Véronique Janod and Giuseppe Nicoletti

418. Reforming Turkey's Public Expenditure Management (February 2005) Rauf Gönenç, Willi Leibfritz and Erdal Yilmaz

417. Fiscal Gimmickry in Europe: One-Off Measures and Creative Accounting (February 2005) Vincent Koen and Paul van den Noord

416. Getting the Most out of Public Sector Decentralisation in Japan (January 2005) Isabelle Joumard and Tadashi Yokoyama 